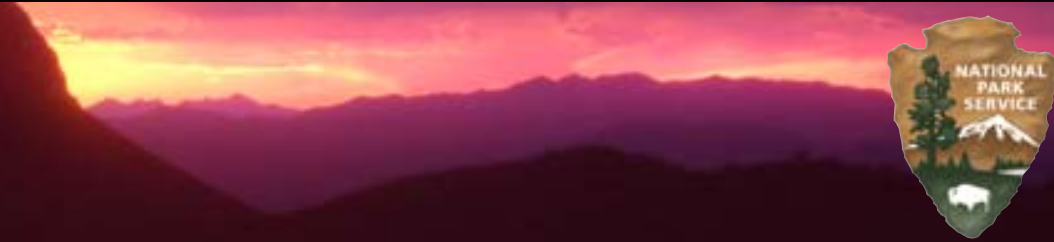

In Cooperation with the University of Arizona, School of Natural Resources

\title{
Vascular Plant and Vertebrate Inventory of Casa Grande Ruins National Monument
}

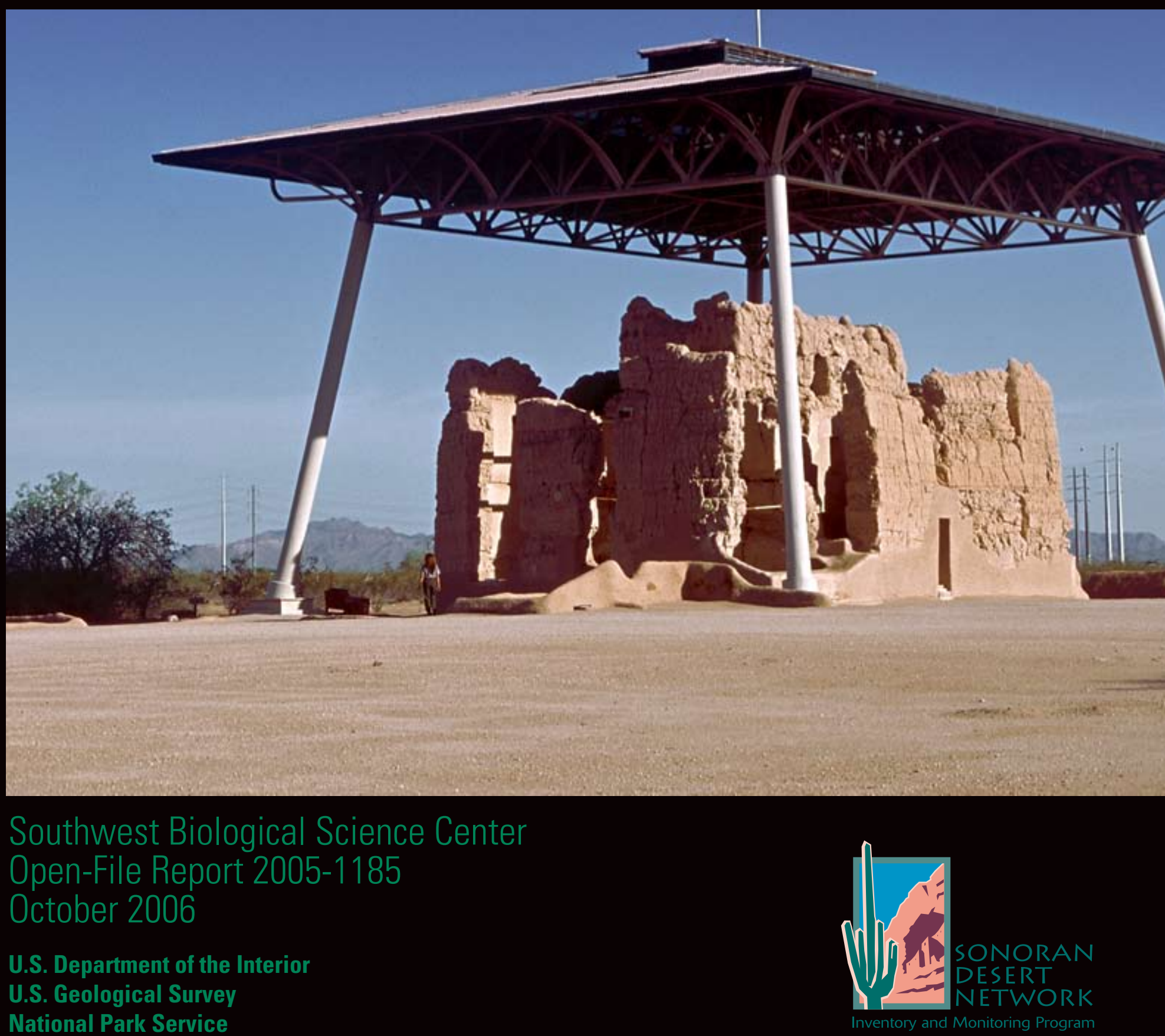



In cooperation with the University of Arizona, School of Natural Resources

\section{Vascular Plant and Vertebrate Inventory of Casa Grande Ruins National Monument}

By Brian F. Powell, Eric W. Albrecht, Cecilia A. Schmidt, William L. Halvorson, Pamela Anning, and Kathleen Docherty

Open-File Report 2005-1185

October 2006

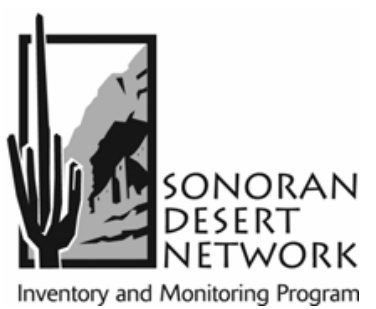

U.S. Department of the Interior

U.S. Geological Survey

National Park Service
USGS Southwest Biological Science Center Sonoran Desert Research Station University of Arizona School of Natural Resources 125 Biological Sciences East Tucson, Arizona 85721 


\title{
U.S. Department of the Interior \\ Dirk Kempthorne, Secretary
}

\author{
U.S. Geological Survey \\ Mark Myers, Director
}

U.S. Geological Survey, Reston, Virginia: 2006

Note: This document contains information of a preliminary nature and was prepared primarily for internal use in the U.S. Geological Survey. This information is NOT intended for use in open literature prior to publication by the investigators named unless permission is obtained in writing from the investigators named and from the Station Leader.

\section{Suggested Citation}

Powell, B. F, E. W. Albrecht, C. A. Schmidt, W. L. Halvorson, P. Anning, and K. Docherty. Vascular Plant and Vertebrate Inventory of Casa Grande Ruins Naitonal Monument. OFR 2005-1185. U.S. Geological Survey, Southwest Biological Science Center, Sonoran Desert Research Station, University of Arizona, Tucson, AZ.

This report supersedes results reported in Powell et al. (2002, 2003, 2004).

Printed on recycled paper

Cover photo: Casa Grande structure, Casa Grande Ruins National Monument, Arizona. Photograph by Brian Powell. 


\section{Authors}

Brian F. Powell

School of Natural Resources

125 Biological Sciences East, Building 43

Kathleen Docherty and Pamela Anning

The University of Arizona

Tucson, AZ 85721

William L. Halvorson

USGS SBSC Sonoran Desert Research Station

125 Biological Sciences East, Building 43

The University of Arizona

Tucson, AZ 85721

\section{U.S. Geological SBSC Survey Sonoran Desert Research Station Personnel}

Charles van Riper III, Station Leader

Steve P. Gloss, Ecologist

William L. Halvorson, Research Ecologist

Cecil R. Schwalbe, Ecologist

Michael R. Kunzmann, Ecologist (Emeritus)

Kathryn Thomas, Ecologist

Pamela Nagler, Physical Scientist

Phil Rosen, Ecologist

\section{Program and Expertise Areas of USGS and UA Personnel}

Administration \& Outreach

Kate Leonard

Jennifer Meador

Wendy Parrish

Emily Sherbrooke

Charles van Riper III

Avian Ecology

Claire Crow

Glenn Johnson

Chris O'Brien

Brian Powell

Charles van Riper III

Data Management

Brent Sigafus

Ecology of Amphibians \& Reptiles

Kevin Baker

Cristina Jones

Dave Prival

Phil Rosen

Cecil Schwalbe

Brent Sigafus
Fire Management

Dennis Suhre

Cori Dolan

James Feldmann

Bill Halvorson

Invasive Species Research

Patricia Guertin

Jim Malusa

Phil Rosen

Cecil Schwalbe

Brent Sigafus

Dennis Suhre

Kathryn Thomas

Inventory \& Monitoring

Patricia Guertin

Bill Halvorson

Pamela Nagler

Brian Powell

Cecilia Schmidt

Vegetation Mapping \& Ecology

Patricia Guertin

Bill Halvorson

Jim Malusa

Kathryn Thomas

USGS Southwest Biological Science Center http://sbsc.wr.usgs.gov

USGS Southwest Biological Science Center, Sonoran Desert Research Station http://sbsc.wr.usgs.gov/sdrs 


\section{Table of Contents}

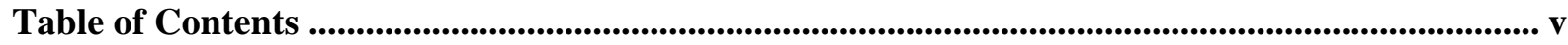

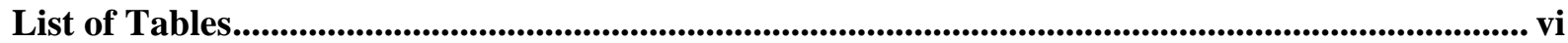

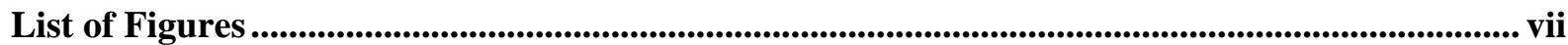

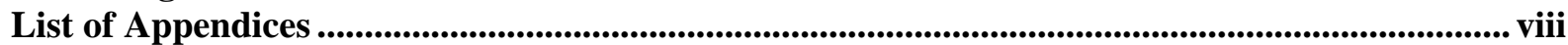

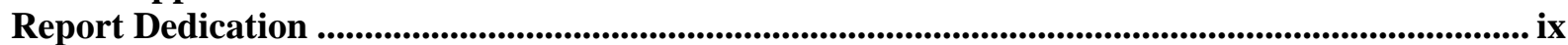

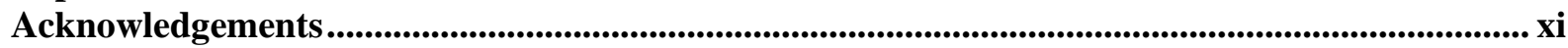

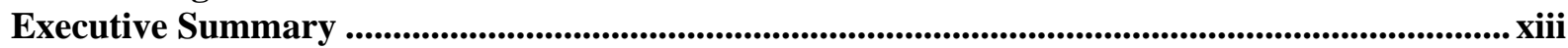

Chapter 1: Introduction to the Biological Inventories ............................................................................. 1

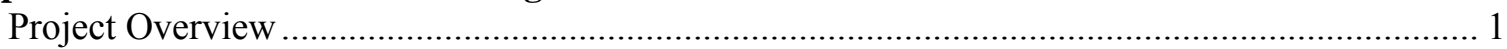

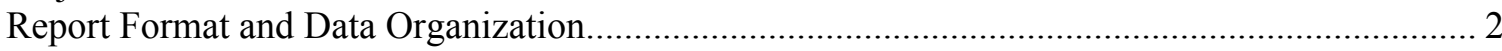

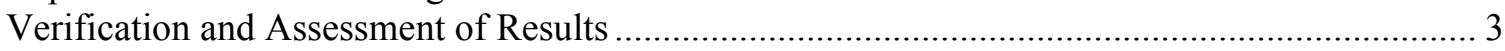

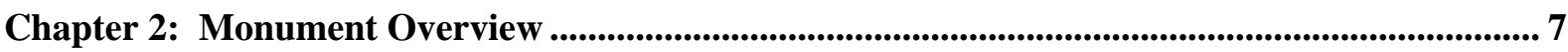

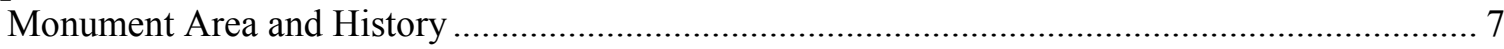

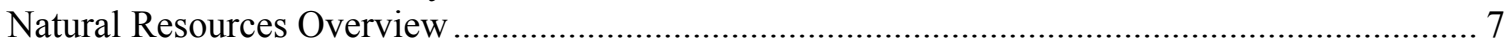

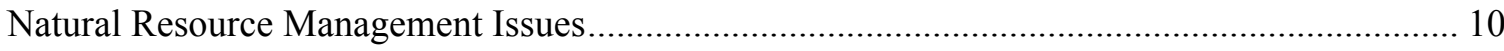

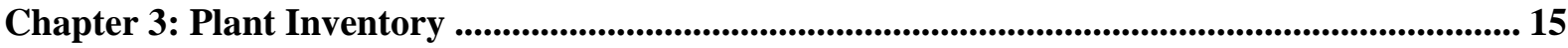

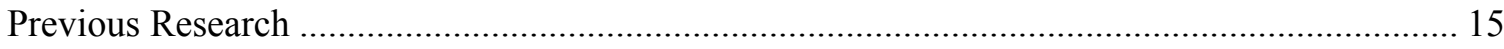

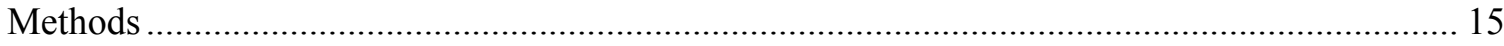

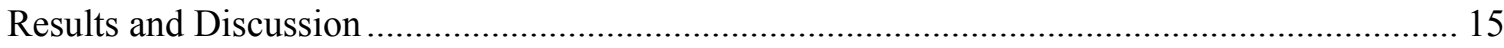

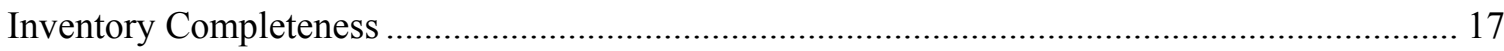

Chapter 4: Amphibian and Reptile Inventory........................................................................................... 19

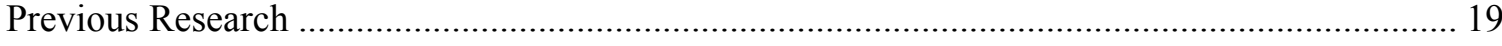

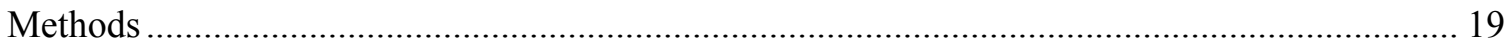

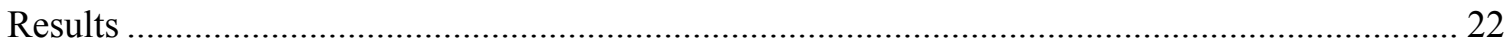

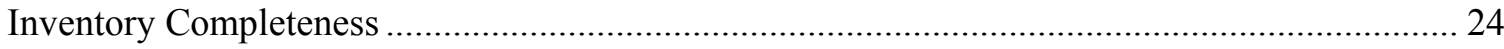

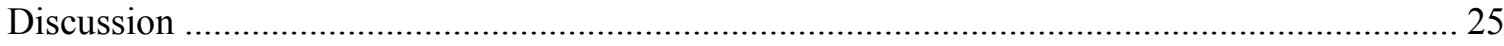

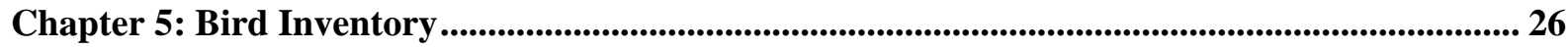

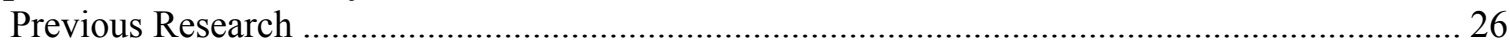

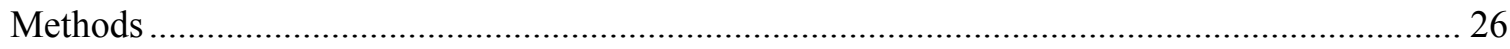

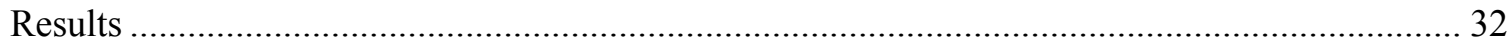

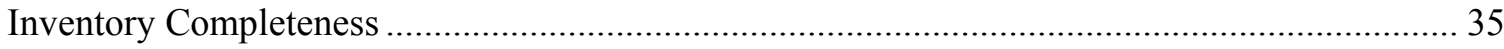

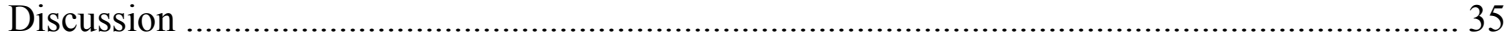

Chapter 6: Mammal Inventory .............................................................................................................. 39

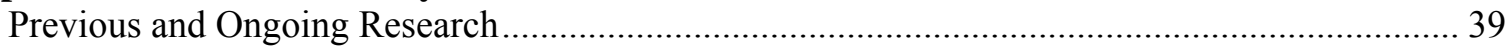

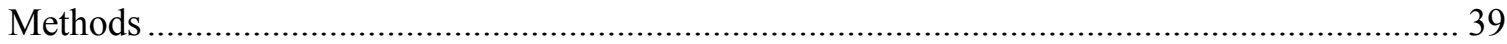

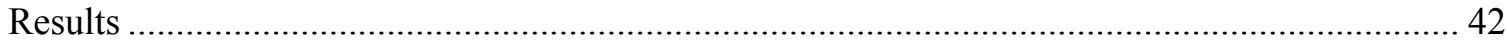

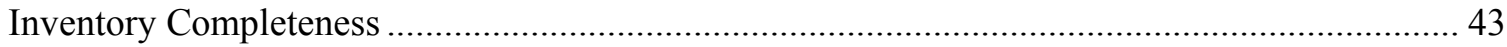

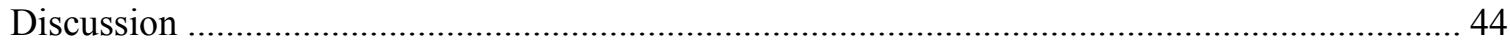

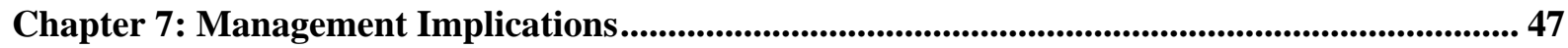

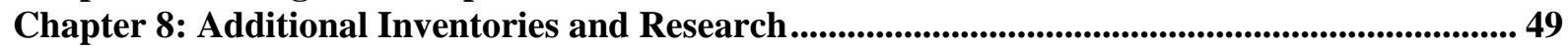

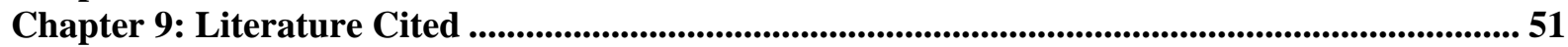




\section{List of Tables}

Table 1. Summary results of the vascular plant and vertebrate inventories at Casa Grande

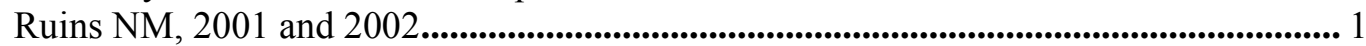

Table 1.1. Museums that were queried in 1998 for vertebrate specimen vouchers with "Arizona" and "Casa Grande Ruins NM" in the collection location................................... 3

Table 2.1. Average monthly climate data for Casa Grande Ruins NM, 1906-1916 and 19322003

Table 4.1. Amphibian and reptile survey effort by method, Casa Grande Ruins NM, 2001 and 2002

Table 4.2. Total number of observations ( $n$ ) and relative abundance (mean and SE) of reptiles recorded during intensive surveys, Casa Grande Ruins NM, 2001 and Total number of observations $(n)$ and relative abundance (mean and SE) of

Table 4.3. Total number of observations ( $n$ ) and relative abundance (mean and SE) of reptiles and amphibians recorded during extensive surveys, Casa Grande Ruins

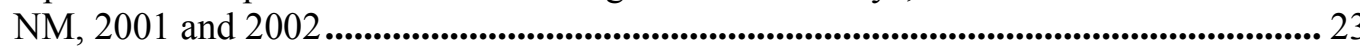

Table 4.4. Total number of observations $(n)$ and number of animals captured per 100 hours of pitfall operation; number of individuals observed during road surveys; and number of incidental observations, Casa Grande Ruins NM, 2001 and 2002 .................. 23

Table 5.1. Number of observations $(n)$ and relative abundance of birds recorded within $75 \mathrm{~m}$ of count stations from VCP surveys, Casa Grande Ruins NM, 2001 and 2002 ............... 32

Table 5.2. Number of observations $(n)$ and frequency of detection of all birds seen or heard during eight-minute counts from VCP surveys, Casa Grande Ruins NM, 2001 and 2002

Table 5.3. Total number of observations $(n)$ and relative frequency of detection of birds recorded during line-transect surveys, Casa Grande Ruins NM, 2002.

Table 5.4. Number of observations for each breeding behavior for birds, Casa Grande Ruins NM, 2001 and 2002. Breeding behaviors follow standards set by NAOAC (1990) ..... 34

Table 6.1. Total number of small mammals trapped (n) and percent relative abundance (PRA), excluding recaptures, Casa Grande Ruins NM, 2002

Table 6.2. Results of Trailmaster camera, incidental collection of sign, and incidental observations by University of Arizona inventory personnel and monument staff, Casa Grande Ruins NM. 


\section{List of Figures}

Figure 2.1. Location of Casa Grande Ruins National Monument, Arizona....................................... 8

Figure 2.2. Aerial photograph of Casa Grande Ruins NM, showing it in a patchwork of commercial and residential development and agricultural fields (A) and a more detailed image of the monument's major features (B)

Figure 2.3. Comparison of monthly weather data during the time of the inventory (2001 and 2002) compared to the mean (1906-1916 and 1932-2003; thick, solid line in both figures; data from WRCC 2004), Casa Grande Ruins NM 12

Figure 3.1. Cumulative number of new plant species found at Casa Grande Ruins NM by four separate studies or collection, from earliest collection to the most recent............... 16

Figure 4.1. Location of intensive survey plots and pitfall-trap array for amphibians and reptiles, Casa Grande Ruins NM, 2001 and 2002 .......................................................... 20

Figure 4.2. Species accumulation curve for intensive and extensive amphibian and reptile surveys, Case Grande Ruins NM, 2001 and 2002 ................................................................. 24

Figure 5.1. Location of VCP survey stations and line-transect sections (winter bird transect) for birds, Casa Grande Ruins NM, 2001 and 2002........................................................ 28

Figure 5.2. Species accumulation curves for detections from all bird surveys combined, Casa

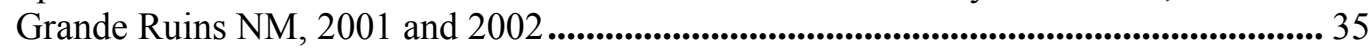

Figure 6.1. Location of small-mammal trapping plots and infrared-triggered cameras, Casa

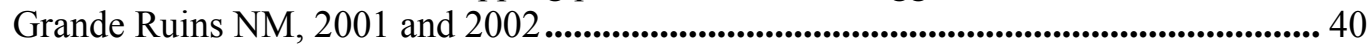

Figure 6.2. Diagram of infrared-triggered camera (Trailmaster) set-up ......................................... 41 Figure 6.3. Species accumulation curve for small-mammal trapping at Casa Grande Ruins NM (2002). 


\section{List of Appendices}

Appendix A. List of plant species observed or documented at Casa Grande Ruins NM by University of Arizona Inventory personnel (I\&M), 2001 and 2002 or other studies or collections.

Appendix B. Amphibian and reptile species documented with photograph $(\mathrm{P})$ or specimen (S) voucher by University of Arizona Inventory personnel, Casa Grande Ruins NM, 2001 and 2002.

Appendix C. Number of observations of birds by University of Arizona Inventory personnel, by survey type, Casa Grande Ruins NM, 2001 and 2002 ............................................. 60

Appendix D. Mammal species observed or documented by University of Arizona Inventory personnel, Casa Grande Ruins NM, 2001 and 2002 .................................................. 61

Appendix E. Amphibian and reptile species not recorded by University of Arizona Inventory personnel but that are likely to occur or have occurred historically at Casa Grande Ruins NM based on collections in the area and expert opinion (P. Rosen in Appendix J) .............................................................................................................. 62

Appendix F. Bird species that were not recorded by University of Arizona Inventory personnel but that may occur at Casa Grande Ruins NM .......................................... 63

Appendix G. Mammal species not recorded by University of Arizona Inventory personnel but that may be found at Casa Grande Ruins NM based on known habitat associations and range.

Appendix H. Vertebrate specimen vouchers from Casa Grande Ruins NM that were not collected by University of Arizona Inventory personnel

Appendix I. Photograph and specimen vouchers collected at Casa Grande Ruins NM by University of Arizona Inventory personnel, 2001 and 2002

Appendix J. Report by Phil Rosen on the expected and historical occurrence of amphibian and reptiles of Casa Grande National Monument ......................................................... 66

Appendix K. Frequency of detections of birds at each VCP station, Casa Grande Ruins NM,

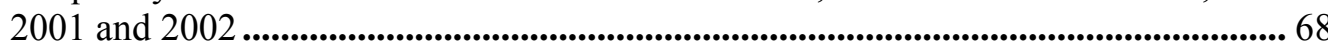

Appendix L. Sum and mean frequency of detection (FD) of all bird observations from VCP surveys during four, two-week time periods, Casa Grande Ruins NM, 2001 and 2002.

Appendix M. Summary of vegetation characteristics measured at bird survey stations, Casa Grande Ruins NM, 2002 


\section{Report Dedication}

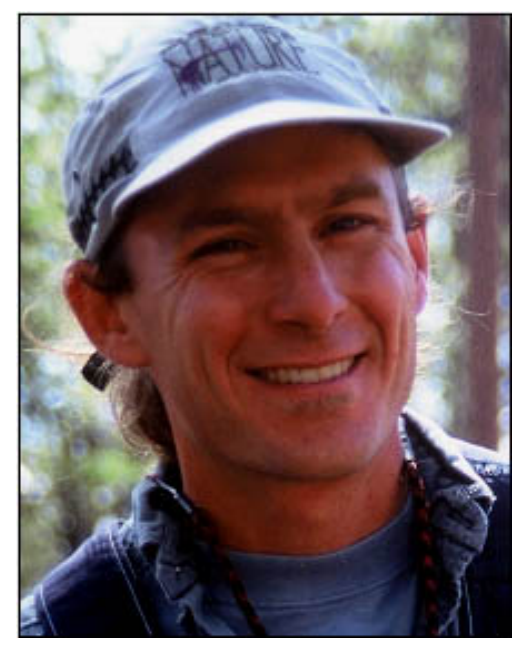

\section{Eric Wells Albrecht 1970-2004}

This report, as others in the series, is dedicated to Eric's life and work; he was an extraordinary ecologist, community member, father, partner, and friend. Eric was co-coordinator of the University of Arizona (UA) biological inventory and monitoring program from 2002 until his sudden and unexpected death on September 20, 2004. Eric was near completion of his MS degree in Wildlife Conservation from the UA, which was awarded posthumously in November 2004. In his last year, Eric spearheaded projects to investigate the efficiency of current monitoring programs; he was passionate about using the best available information to guide vertebrate monitoring efforts in the region. He is survived by his partner, Kathy Moore, and their two young children, Elizabeth and Zachary. We hope that the lives of his children will be enriched by Eric's hard work on behalf of the national parks in the Sonoran Desert Network. 


\section{Acknowledgements}

Thanks to Superintendents Paige Baker and Donald Spencer at Casa Grande Ruins National Monument (NM) for their support of our program. Other monument staff that supported our efforts included: Dawn Daw, Jolene Johnson, Denise Shultz, Carol West, and David Winchester. This project resulted from the collaboration of many people at the University of Arizona (UA), National Park Service (NPS), and U.S. Geological Survey (USGS), and was facilitated by the Desert Southwest and Colorado Plateau Cooperative Ecosystem Studies Units (CESUs). The NPS Natural Resource Challenge program funded the project. Larry Norris, NPS Research Coordinator, spent considerable time and effort providing clear and timely administrative assistance on all aspects of the inventory project. The Southern Arizona Office of the NPS facilitated development of the original study plan that led directly to initiation of this project. Andy Hubbard, Network Coordinator of the Sonoran Desert Network (SDN) Inventory and Monitoring (I\&M) program, has been a strong and convincing advocate for continuing and expanding the role of the USGS/UA Inventory project. Kathy Davis at Tuzigoot and Montezuma Castle national monuments played an instrumental role in this project by providing important early initiative. Matt Goode, Don Swann, and Dale Turner provided much of the early planning for this project; we are indebted to their vision and work. Eric Albrecht, to whom this report is dedicated, was an outstanding spokesperson and leader of the program; he was an invaluable member of the team and his contributions are sorely missed.

We thank a core group of dedicated field biologists who collected a wealth of data at Casa Grande Ruins NM: Theresa Dekoker, James MacAdam, and Meg Quinn (plants); Dan Bell, Kevin Bonine, James Borgmeyer, Charles Conner, Dave Prival, Angela Urbon, and Mike Wall (amphibians and reptiles); Gavin Beiber, Chris Kirkpatrick, and Gabe Martinez (birds); Neil Perry, Jason Schmidt, and Ronnie Sidner (mammals). We are appreciative of the following people, many of whom never ventured into the field, but whose work in the office made the field effort more successful: Debbie Angell, Jennifer Brodsky, Brian Cornelius, Taylor Edwards, Carianne Funicelli, Colleen McClain, Heather McClaren, Lindsay Norpel, Jill Rubio, Brent Sigafus, Taffy Sterpka, Patina Thompson, Jenny Treiber, and Alesha Williams.

Additional administrative support was provided by Valery Catt at the USGS Sonoran Desert Research Station and Terri Rice, Andy Honaman, Jenny Ferry, and especially Cecily Westphal of the School of Natural Resources at the UA. Special thanks to Lisa Carder for her years of hard work on all aspects of the project. Technical support was graciously given by the following experts: Dan Austin, Michael Chamberland, Phil Jenkins, and Charlotte and John Reeder at the UA herbarium; George Bradley of the UA herpetology collection; Tom Huels of the UA ornithology collection; and Yar Petryszyn and Melanie Bucci of the UA mammal collection. Thanks to Sharon Megdal and Peter Wierenga, the current and former directors, respectively, of the UA Water Resources Research Center, and all their staff.

The amphibian and reptile chapter greatly benefited from review and contributions by Phil Rosen. Brooke Gebow edited the document and provided excellent suggestions for improving the text. Other reviewers were: Debbie Angell, Shirley Hoh, Andy Hubbard, Theresa Mau-

Crimmins, Don Swann, and Carol West. All mistakes and omissions are the responsibility of the authors. 


\section{Executive Summary}

This report summarizes results of the first comprehensive biological inventory of Casa Grande Ruins National Monument (NM) in southern Arizona. Surveys at the monument were part of a larger effort to inventory vascular plants and vertebrates in eight National Park Service units in Arizona and New Mexico. In 2001 and 2002 we surveyed for vascular plants and vertebrates (amphibians, reptiles, birds, and mammals) at Casa Grande Ruins $\mathrm{NM}$ to document the presence, and in some cases relative abundance, of species. By using repeatable study designs and standardized field techniques, which included quantified survey effort, we produced inventories that can serve as the basis for a biological monitoring program.

Of the National Park Service units in the region, no other has experienced as much recent ecological change as Casa Grande Ruins NM. Once situated in a large and biologically diverse mesquite bosque near the perennially flowing Gila River, the monument is now a patch of sparse desert vegetation surrounded by urban and commercial development that is rapidly replacing agriculture as the dominant land use in the area. Roads, highways, and canals surround the monument. Development, and its associated impacts, has important implications for the plants and animals that live in the monument. The plant species list is small and the distribution and number of non-native plants appears to be increasing. Terrestrial vertebrates are also being impacted by the changing landscape, which is increasing the isolation of these populations from nearby natural areas and thereby reducing the number of species at the monument. These observations are alarming and are based on our review of previous studies, our research in the monument, and our knowledge of the biogeography and ecology of the Sonoran Desert. Together, these data suggest that the monument has lost a significant portion of its historic complement of species and these changes will likely intensify as urbanization continues.

Despite isolation of the monument from nearby natural areas, we recorded noteworthy species or observations for all taxonomic groups:

- Plants: night-blooming cereus

- Amphibians: high abundance of Couch's spadefoot toads

- Reptiles: high abundance of long-nosed snakes

- Birds: 10 species of diurnal raptors including 4 species of falcons

- Mammals: American badger

This study is a first step in the process of compiling information about the biological resources of Casa Grande Ruins NM and surrounding areas. We recommend additional inventory and research studies, and we identify aspects of our effort that could be improved upon through application of new techniques or by extending the temporal (and possibly spatial) scope of our work.

Table 1. Summary results of the vascular plant and vertebrate inventories at Casa Grande Ruins NM, 2001 and 2002.

\begin{tabular}{|c|c|c|c|}
\hline Taxonomic group & $\begin{array}{c}\text { Number of } \\
\text { species recorded }\end{array}$ & $\begin{array}{c}\text { Number of } \\
\text { non-native species }\end{array}$ & $\begin{array}{l}\text { Number of new species } \\
\text { added to monument list }\end{array}$ \\
\hline Plants & 60 & 12 & 21 \\
\hline Birds & 82 & 3 & 70 \\
\hline Mammals & 13 & 2 & 7 \\
\hline
\end{tabular}

a Species that had not been observed or documented by previous studies. 


\section{Chapter 1: Introduction to the Biological Inventories}

\section{Project Overview}

\section{Inventory: A point-in-time effort to document the resources present in an area.}

In the early 1990s, responding to criticism that it lacked basic knowledge of natural resources within parks, the National Park Service (NPS) initiated the Inventory and Monitoring Program (I\&M) to detect long-term changes in biological resources (NPS 1992). At the time of the program's inception, basic information, including lists of plants and animals, was absent or incomplete for most park units (Stohlgren et al. 1995). Inventory data were particularly lacking for smaller parks (such as Casa Grande Ruins National Monument [NM]), many of which were created to protect cultural resources, but which also contain important natural resources.

Species inventories have both direct and indirect value for management of the park and are an important first step in long-term monitoring. Species lists are not only useful in resource interpretation and facilitating visitor appreciation of natural resources, but are also critical for making management decisions. Knowledge of which species are present, particularly sensitive species, and where they occur provides for informed planning and decision-making (e.g., locating new facilities). Thorough biological inventories provide a basis for choosing parameters to monitor, and can provide baseline data for monitoring ecological populations and communities. Inventories can also test sampling designs, field methods, and data collection protocols, as well as provide estimates of variation that are essential in prospective power analysis.

\section{Goals}

The purpose of this study was to complete basic inventories for vascular plants and vertebrates at Casa Grande Ruins NM. This effort was part of a larger biological inventory of eight NPS units in southern Arizona and southwestern New Mexico
(Davis and Halvorson 2000, Powell et al. 2004, 2005). Our goals were to:

1. Conduct field surveys with the goal of documenting at least $90 \%$ of all species of vascular plants and vertebrates expected to occur within the current monument boundary.

2. Use repeatable sampling designs and survey methods (when appropriate) that allow estimation of parameters of interest (e.g., relative abundance by taxonomic group) with associated estimates of precision.

3. Compile historic occurrence data from museum records (specimen vouchers), previous studies, and monument records.

4. Create resources useful to monument managers, including detailed species lists, maps of study sites, and highquality digital images for use in resource interpretation and education.

The bulk of our effort addressed goals number 1 and 2. To maximize efficiency (i.e., the number of species recorded by effort) we used field techniques designed to detect multiple species. We did not undertake single-species surveys for threatened or endangered species. Finally, although pest species are a significant management concern at the monument (NPS 1997), we did not evaluate habitat use and therefore cannot comment on the relative contribution of species to the degradation of the monument's cultural resources (e.g., Swann et al. 1994).

\section{Administrative History}

The original study plan for this project was developed, and an inventory of one park unit (Tumacácori National Historical Park) was completed through a cooperative agreement among NPS, University of Arizona (UA), and the United States Geological Survey (USGS). This 
project was funded through Task Agreements UAZ-03, UAZ-05, and UAZ-06 (under the Colorado Plateau Cooperative Ecosystems Studies Unit [CESU] cooperative agreement number 1200-99-009). NPS thereafter obligated additional funds through the Colorado Plateau CESU (UAZ-07) and the Desert Southwest CESU (cooperative agreement number CA124800-002, reference UAZ-39, UAZ-77, UAZ-87, UAZ-97, and UAZ-128) for administration and management of the biological inventories.

\section{Report Format and Data Organization}

In the text, we report both common and scientific names for plants and only common names for vertebrates (listed in phylogenetic sequence), unless we reference a species that is not listed later in an appendix; in this case, we present both common and scientific names. For each taxonomic group we include an appendix of all species that we recorded in the monument (Appendices A-D) and vertebrate species that were likely present historically or that we suspect are currently present and may be recorded with additional survey effort (Appendices E-G). Scientific and common names used throughout this document are current according to accepted authorities for each taxonomic group: Integrated Taxonomic Information System (ITIS 2005) and the PLANTS database (USDA 2005) for plants; Stebbins (2003) for amphibians and reptiles; American Ornithologists' Union (AOU 1998, 2003) for birds; and Baker et al. (2003) for mammals. The designation of a plant as "nonnative" using the aforementioned lists may lead to the misclassification of some species, because these lists indicate only species status in North America as a whole, not regions within the continent. Therefore, our flora underestimates the number of non-native species, but because no authoritative list of non-native species exists for the region, we believe that use of these lists is justified.

\section{Spatial Data}

Most spatial data are geographically referenced to facilitate mapping of study plots and locations of plants and animals. Coordinates were stored in the Universal Transverse Mercator (UTM) projection (Zone 12), using the North American Datum of 1983 (NAD 83). We recorded UTM coordinates using hand-held Garmin E-Map ${ }^{\circledR}$ Global Positioning System (GPS) units (Garmin International Incorporated, Olathe, KS; horizontal accuracy approximately $10-30 \mathrm{~m}$ ). We obtained some plot or station locations by using more accurate Trimble Pathfinder ${ }^{\circledR}$ GPS units (Trimble Navigation Limited, Sunnyvale, CA; horizontal accuracy about $1 \mathrm{~m}$ ). Although we map the locations of study plots, stations, or transects on Digital Orthophoto Quarter Quads (DOQQ; produced by the USGS), UTM coordinates will remain with the park and the NPS Sonoran Desert Network I\&M office in Tucson.

\section{Species Conservation Designations}

We indicate species conservation designations by the following agencies: U.S. Fish and Wildlife Service (responsible for administering the Endangered Species Act), USDA Forest Service, Arizona Game and Fish Department, and Partners in Flight (a partnership of dozens of federal, state and local governments, non-governmental organizations, and private industry).

\section{Databases and Data Archiving}

We entered field data into taxon-specific databases (Microsoft Access version 97) and checked all data for transcription errors. From these databases we reproduced copies of the original field datasheets using the "Report" function in Access. The output looks similar to the original datasheets but data are easier to read. The databases, printouts of field data, and other data such as digital photographs will be distributed to park staff and to Special Collections at the University of Arizona. Original copies of all datasheets currently reside at the I\&M office in Tucson and may be permanently archived at another location, most likely the Western Archaeological Conservation Center in Tucson (Andy Hubbard, pers. comm.). Along with the archived data we will include copies of the original datasheets and a guide to filling them out. 
This information, in conjunction with the text of this report, should enable future researchers to repeat our work.

\section{Verification and Assessment of Results}

\section{Photograph Vouchers}

Whenever possible, we documented vertebrate species with analog color photographs. Many of these photographs show coloration or other characteristics of visual appearance in detail, and they may serve as educational tools for the park staff and visitors. If possible, we obtained a close-up photograph of each animal "in hand" and another photograph of the animal in natural surroundings. Photographs will be archived with other data as described above.

\section{Specimen Vouchers}

Specimen vouchers are an indisputable form of evidence of a species occurrence. For plants, we searched the University of Arizona Herbarium for existing specimens from the monument (see Appendix A for results) and we collected herbarium specimens whenever flowers or fruit were present on plants in the field. All specimens that we collected were accessioned into the University of Arizona Herbarium. We searched for vertebrate specimens from Casa
Grande Ruins NM in records from 48 natural history museums (Table 1.1; see Appendix H for results). When we did collect specimens, most were found dead. When necessary, we euthanized animals according to standardized and approved procedures, prepared the specimens using accepted methods, and deposited them in the appropriate collection at the University of Arizona.

\section{Assessing Inventory Completeness}

We assessed inventory completeness by (1) examining the rate at which new species were recorded in successive surveys (i.e., species accumulation curves; Hayek and Buzas 1997) and (2) comparing the list of species we recorded with a list of species likely to be present based on previous research and/or expert opinion. We created species accumulation curves for all taxonomic groups except plants. For all accumulation curves (unless indicated otherwise), we randomized the order of the sampling periods to break up clusters of new detections that resulted from temporal conditions (e.g., monsoon initiation) independent of cumulative effort.

\section{Estimating Abundance}

Estimating population size is a common goal of biologists who are motivated by the desire to reduce (pest species), increase (endangered

Table 1.1. Museums that were queried in 1998 for vertebrate specimen vouchers with "Arizona" and "Casa Grande Ruins NM" in the collection location.

\begin{tabular}{ll}
\hline Brigham Young University & Oklahoma Museum of Natural History, Norman \\
Chicago Academy of Sciences & Peabody Museum, Yale University \\
Cincinnati Museum of Natural History \& Science & Saguaro National Park (collection now at the Western \\
Cornell Vertebrate Collections, Cornell University & Archeological and Conservation Center, Tucson \\
George Mason University (Fairfax, VA) & Strecker Museum, Baylor University, Waco \\
Illinois Natural History Survey & Texas Cooperative Wildlife Collection \\
Marjorie Barrick Museum, University of Nevada-Las Vegas & Tulane Museum of Natural History \\
Michigan State University Museum (East Lansing) & University of Arizona \\
Milwaukee Public Museum & University of Texas, Arlington \\
Museum of Natural History, University of Kansas & University of Illinois, Champaign-Urbana \\
Museum of Texas Tech University & University of Colorado Museum \\
Museum of Vertebrate Zoology, University of California, Berkeley & United States National Museum \\
Museum of Life Sciences, Louisiana State University, Shreveport & Walnut Canyon National Monument, Arizona \\
Natural History Museum of Los Angeles County & Western Archaeological and Conservation Center, Tucson \\
North Carolina State Museum of Natural Sciences & Wupatki National Monument, Flagstaff \\
\hline
\end{tabular}


species), maintain (game species) or monitor (indicator species) population size. Our surveys at the park were generally focused on detecting species rather than estimating population size. In many cases, however, we present estimates of "relative abundance" by species to provide information on areas in which species might be more or less common. Relative abundance is an index to population size; we calculate it as the number of individuals recorded, scaled by survey effort. If we completed multiple surveys in comparable areas, we included a measure of precision (usually standard error) with the mean of those survey results.

Indices of abundance are presumed to correlate with true population size but ecologists do not typically attempt to account for variation in detectability among different species or groups of species under different circumstances.
Metrics (rather than indices) of abundance do consider variation in detection probability, and these include density (number of individuals per unit area; e.g., one long-nosed snake per $\mathrm{km}^{2}$ ) and absolute abundance (population size; e.g., 10 long-nosed snakes at the monument). These estimates are beyond the scope of our research. While it is true that indices of abundance have often been criticized (and with good reason, c.f. Anderson 2001), the abundance information that we present in this report is used to characterize the commonness of different species rather than to quantify changes in abundance over long periods of time (e.g., monitoring). As such, relative abundance estimates are more useful than detectability-adjusted estimates of density for only a few species or raw count data for all species without scaling counts by survey effort. 


\section{Chapter 2: Monument Overview}

\section{Monument Area and History}

Casa Grande Ruins NM is located in Coolidge, Arizona, approximately $70 \mathrm{~km}$ southeast of Phoenix (Fig. 2.1). The monument currently encompasses 191 contiguous ha, but managers are proposing to increase the size of the monument by approximately 105 ha (including 32 ha adjacent to the current site [NPS 2003a]).

Casa Grande Ruins NM was created to protect the Casa Grande, a four-story adobe structure that was built by the Hohokam between AD 1200 and 1450 (Clemensen 1992). The Hohokam had a sophisticated culture - they built extensive canals to irrigate crops and provide water to large communities in the vicinity of the Casa Grande. After the mysterious departure of the Hohokam in approximately 1450, the Casa Grande stood abandoned for nearly 450 years until, in 1892, the structure and the land surrounding it became the first U.S. prehistoric cultural site to receive federal protection (Clemensen 1992). In 1918, Casa Grande Ruins became part of the National Park Service system. Today the monument hosts approximately 120,000 visitors per year (NPS 2004).

\section{Natural Resources Overview}

\section{Physiography, Geology, and Soils}

The monument is located approximately $1 \mathrm{~km}$ south of the Gila River, which now only flows seasonally. The Pima Lateral canal runs parallel to (and a few meters from) the southern boundary of the monument and a smaller irrigation ditch parallels the west boundary (Fig. 2.2). State Highway 87 runs along the east and north boundaries of the monument.

The monument is situated at approximately $430 \mathrm{~m}$ above sea level in the Basin and Range Physiographic Province, which is characterized by gently sloping valley floors surrounded by mountain ranges. The monument is characterized by Quaternary and Tertiary alluvial deposits (fluvial and lacustrine) from the surrounding mountain ranges: San Tan Mountains (s6 km north), Sacaton (16 km west), Picacho (30 km southeast), and Casa Grande (30 km southwest). The mountains bordering the valley floor are composed of non-water-bearing Precambrian granite, gneiss, and schist (Van Pelt 1998). All mountain ranges are currently isolated from each other by agriculture and development. Soil at the monument is Coolidge sandy loam, with caliche two to four feet below the surface.

\section{Hydrology}

The Gila River is the main water body in the region, but impoundments upstream from the monument cause the river to run dry for most of the year in the reach to the north of the monument. Irrigation canals carry water for crops, while water for developments comes from groundwater pumping (Sprouse et al. 2002). Pumping has significantly impacted the vegetation composition and structure of the monument (see section below on natural resource issues; Van Pelt 1998) and poses the threat of soil subsidence and fissure development for the Casa Grande.

\section{Climate}

Casa Grande Ruins NM is located in the subtropical desert climatic zone of southern Arizona, which is characterized by heavy summer (monsoon) storms brought about by moisture coming from the Gulf of Mexico and less intense, frontal storms from the Pacific Ocean in the winter. The monument receives an average of $23 \mathrm{~cm}$ of precipitation annually (Table 2.1; WRCC 2004). Summers in the area are hot; daily maximum temperatures from June through September often exceed $40{ }^{\circ} \mathrm{C}$. Winters are mild and temperatures rarely drop below freezing (Table 2.1; WRCC 2004).

Average annual precipitation totals during the course of our study were slightly above the long-term mean of $22.8 \mathrm{~cm}$ in 2001 


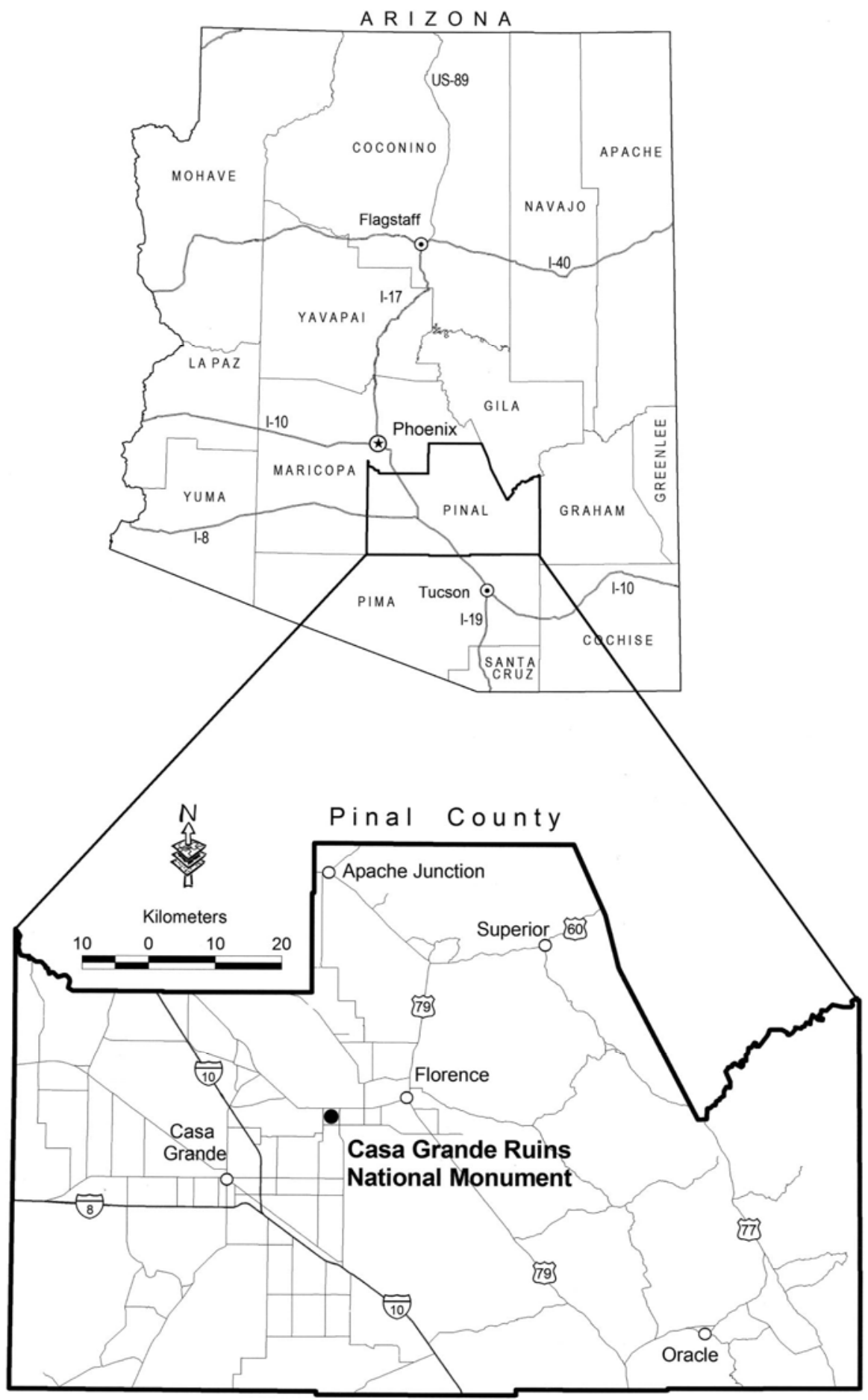

Figure 2.1. Location of Casa Grande Ruins National Monument, Arizona. 


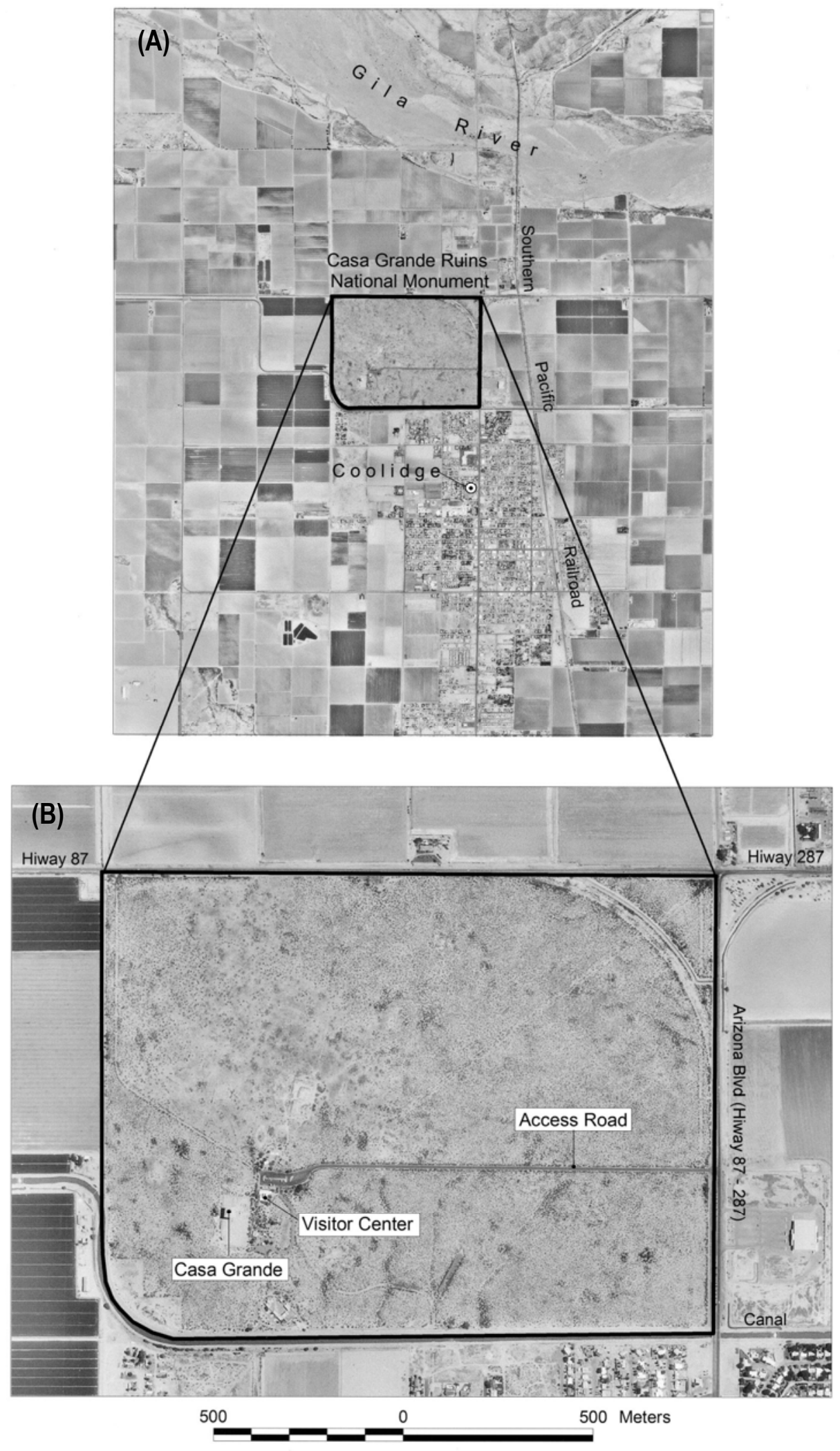

Figure 2.2. Aerial photograph of Casa Grande Ruins NM, showing it in a patchwork of commercial and residential development and agricultural fields (A) and a more detailed image of the monument's major features (B). 
(24.7 $\mathrm{cm}$ ) but considerably lower than average in $2002(12.2 \mathrm{~cm})$, which was one of the driest years on record (Fig. 2.3; WRRC 2004). In the fall of 2000 rainfall was above average (Fig. 2.3); this rain may have increased winter annual plant seed germination and growth prior to our 2001 spring plant surveys. Average annual temperatures during both years of our study were $0.9^{\circ} \mathrm{C}$ above the long-term mean of $20.8^{\circ} \mathrm{C}$.

\section{Vegetation}

\section{Current Conditions}

The relatively homogenous vegetation community at Casa Grande Ruins NM is characterized as Sonoran desertscrub dominated by creosote with scattered velvet mesquite, saltbush and annual grasses and forbs (Reichhardt 1992). Shrubs and trees in the vicinity of the visitor center are irrigated, and the many standing dead velvet mesquite trees in other areas of the monument reference a change from historic conditions.

\section{Historical Conditions}

Because the area in and around the monument has been intensely used for hundreds of years, it is difficult to determine the "natural" vegetation community of the area. Given the monument's close proximity to the Gila River, coupled with the topographic and soil conditions of the site, it is likely that the area was once a vast mesquite bosque, especially before colonization by the Hohokam. Even since the abandonment of the area by the Hohokam, many large mesquite trees dominated the area, as noted by late $19^{\text {th }}$ Century visitors (Clemensen 1992). Subsequent cattle grazing probably enabled the increase in woody shrubs such as creosote, catclaw acacia, and saltbush (Clemensen 1992). However, in the mid- to late-1930s, the large mesquites at the monument began to die off, apparently due to a drop in the groundwater level related to overpumping for agricultural irrigation (Judd et al. 1971, Clemensen 1992, Nickens 1996). The die-off of mesquites likely changed the water retention capacity of the soil, leading to the die-off of salt bush and catclaw acacia, thereby creating conditions favorable to proliferation of creosote, which now dominates at the monument.

\section{Historical Land Use of the Monument and} Surrounding Areas

Clemensen (1992) compiled a detailed history of Casa Grande Ruins NM and the following information comes from his work. Beginning in the 1870 s, settlers began grazing cattle in the area because of the abundant forage. Grazing continued until 1934 when the monument was fenced to exclude cattle. But it was agriculture that would become the dominant land use of the area outside the monument, and beginning in the 1880s settlers began in earnest to clear land in the vicinity of the monument. Water for irrigating crops (fruit trees, grapes, cereal grains, cotton, lettuce, and alfalfa) came first from direct diversion of flow from the Gila River, and later from above-ground storage with the construction of nearby Coolidge Dam in the mid 1920s and groundwater accessed by pumping. In 1925 the town of Coolidge was created and by 1932 the monument was surrounded by agricultural fields. However, by 1947, agricultural fields were being abandoned because of drought and a lowered water table, due in large part to over-pumping. Depth-to-water rebounded somewhat by the late 1990s, in part because of reduced groundwater pumping (Sprouse et al. 2002).

\section{Natural Resource Management Issues}

Casa Grande Ruins NM is an isolated patch of desert vegetation surrounded by intensively altered land; uses include agriculture, residential and commercial development, and roads. Although it is difficult to quantify the effect of these land uses, these (and other) influences inevitably affect the structure and composition of plant and animal communities of the monument.

\section{Agriculture}

Agricultural fields bordering the monument to the west and north are typical of the dominant land use in the surrounding area. These areas provide disturbed soils and only marginal space for other plants to grow, space that is typically occupied by non-native "weedy" plants including redstem stork's bill, red brome, Russian thistle, and 
Johnsongrass. In addition, the canals that border the monument are periodically dredged and the sediment (likely rich in non-native plant seed) is deposited along the edge of the monument boundary (Hubbard et al. 2003).

Farmers typically use pesticides and herbicides to maintain high agricultural yields, but because insects are the primary food for many animals (e.g., many species of birds rely on invertebrates during the breeding season; Ehrlich et al. 1988) the loss or contamination of this prey base can cause mortality, impaired health (e.g., decreased reproductive success or increased susceptibility to disease), and abandonment of the area in search of a viable prey base (Best 1992, Freemark and Boutin 1995, Boutin et al. 1999). Pesticides can also alter nutrient and energy flows and the chemical composition of plants (Pimentel and Edwards 1982). The overspray, or "drift" of herbicides to adjacent areas (such as the monument) following aerial application, can adversely affect non-target vegetation (Freemark and Boutin 1995), again lowering reproductive success and reducing fitness of plants and animals (Fletcher et al. 1993). Herbicides and fertilizers alter vegetation composition by favoring certain plants and killing others (Tietjen et al. 1967, Fagerstone et al. 1977). Agricultural byproducts (including sediment, fertilizers, pesticides, herbicides, and dust) can reduce air quality and contaminate surface water and groundwater (Freemark and Boutin 1995, Bohlke 2002).

Due to concern expressed by monument personnel, Currie (1998) conducted a review of pesticide and herbicide applications on lands adjacent to the monument. He found scant information on the type and extent of the aerial application of these chemicals and recommended steps for acquiring additional information. To our knowledge there has been no follow-through on his recommendations.

\section{Residential and Commercial Development}

Casa Grande Ruins NM is located within the City of Coolidge. The city's population $(7,786$ inhabitants in 2000) is increasing rapidly, leading to increased residential and commercial development (NPS 2003a, 2003b). Large-scale commercial developments (e.g., Wal-Mart ${ }^{\circledR}$ ) have been built along Highway 87 across from the monument. Residential development abuts the south boundary and is planned along the west boundary should the proposed monument boundary expansion not be approved. Impacts of these developments on the monument's natural resources may include: (1) an increase in nonnative plants (e.g., the first sighting of a common plant used in landscaping, crimson fountaingrass, was reported by Halvorson and Guertin [2003]); (2) increased trash and run-off of sediment and toxins from vehicles; (3) disruption of animal movement patterns; and (4) increased harassment and mortality of native animals by free-roaming feral pets (Clarke and Pacin 2002). The change in land use adjacent to the monument from agriculture to urban development likely has positive aspects as well, including reduction of pesticide/herbicide overspray (though the extent of the impacts on the monument has never been established).

\section{Roads}

Casa Grande Ruins NM is completely encircled by roads, most notably Highway 87 (Fig. 2.2), the primary highway in the area. Roads act as

Table 2.1. Average monthly climate data for Casa Grande Ruins NM, 1906-1916 and 1932-2003. Data summarized from WRCC (2004).

\begin{tabular}{lrrrrrrrrrrrrr}
\hline & \multicolumn{11}{c}{ Month } \\
\cline { 2 - 13 } Characteristic & Jan & Feb & Mar & Apr & May & Jun & Jul & Aug & Sep & Oct & Nov & Dec & Annual \\
\hline Maximum temperature $\left({ }^{\circ} \mathrm{C}\right)$ & 19.6 & 22.1 & 25.2 & 30.3 & 35.3 & 40.5 & 41.5 & 40.3 & 38.2 & 32.1 & 24.7 & 19.7 & 30.8 \\
Minimum temperature $\left({ }^{\circ} \mathrm{C}\right)$ & 1.2 & 2.7 & 5.1 & 8.3 & 12.6 & 17.6 & 23.3 & 22.7 & 18.7 & 11.4 & 4.6 & 1.4 & 10.8 \\
Total precipitation $(\mathrm{cm})$ & 2.2 & 2.1 & 2.3 & 0.9 & 0.4 & 0.3 & 2.8 & 3.1 & 2.0 & 1.8 & 1.9 & 2.9 & 22.8 \\
\hline
\end{tabular}



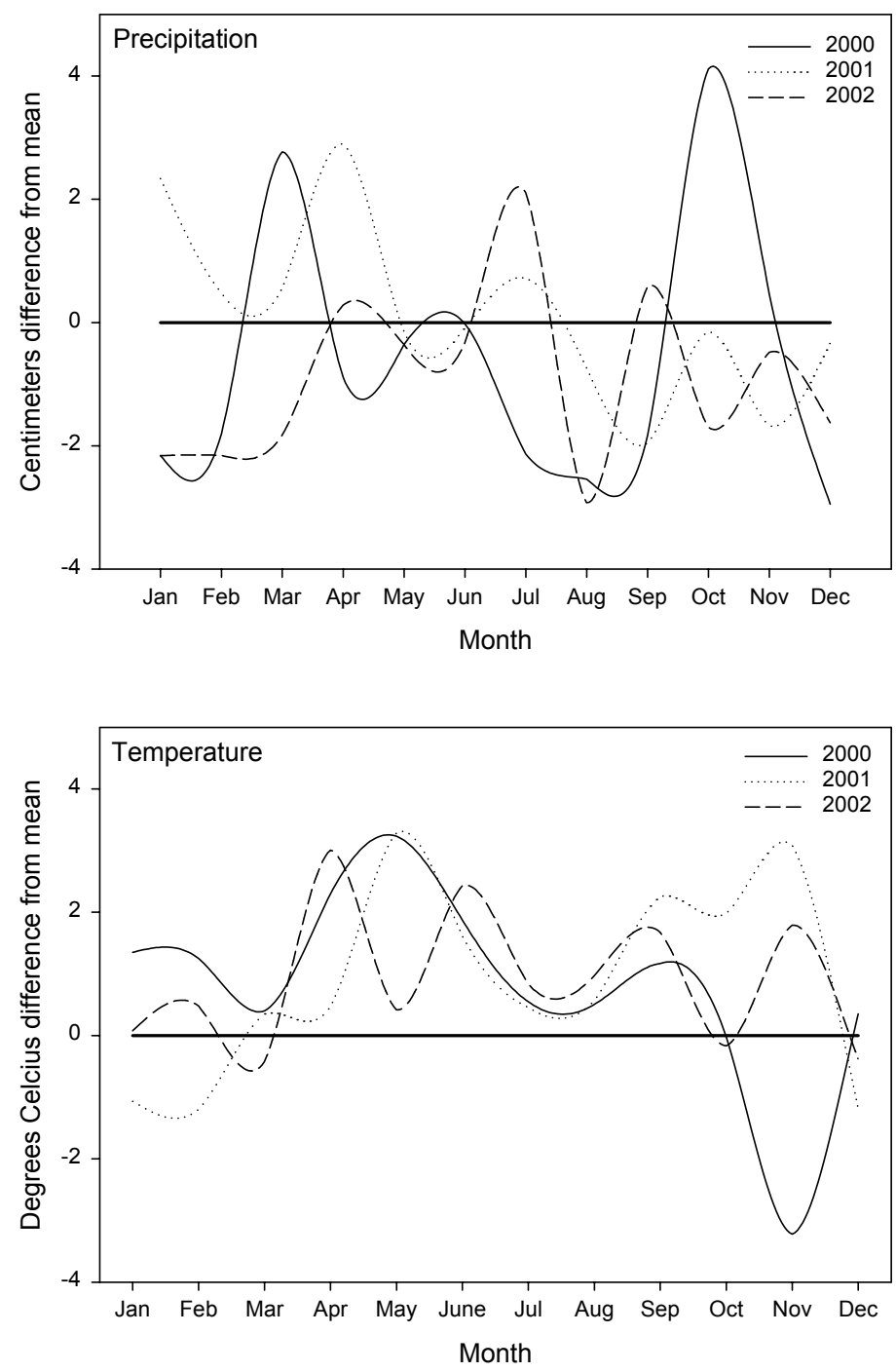

Figure 2.3. Comparison of monthly weather data during the time of the inventory (2001 and 2002) compared to the mean (1906-1916 and 1932-2003; thick, solid line in both figures; data from WRCC 2004), Casa Grande Ruins NM. Data from 2000 are included to show conditions prior to fieldwork.

dispersal corridors for non-native plant species, which often thrive in the adjacent disturbed soils. Roads surrounding the monument likely act as barriers to the flow of terrestrial wildlife because of direct mortality and modification of behavior (Trombulak and Frissell 2000, Clark et al. 2001, Tigas et al. 2002, Cain et al. 2003).

\section{Changes in Land-Use Type}

Each species responds in different ways to the mosaic of land-use types (roads, canals, agricultural fields, and development) that surround the monument. While this matrix may function as habitat for species such as the house cat and domestic dog, these human-altered landscapes create barriers to movement, threats to essential resources, and occasionally direct mortality of most native species. While it is beyond the scope of this project to delineate habitat requirements of species or determinants of species composition, existing research indicates that changes such as urban development, agriculture, and road construction have significant 
impact on presence, abundance, and life-history functions (e.g., ability to reproduce or forage) of native plants and animals. As agricultural fields give way to commercial and high- or moderate-density residential development, the repercussions of urbanization on the native plants and animals at Casa Grande NM will likely intensify.

\section{Groundwater Pumping}

The continued pumping of groundwater for agricultural, residential, and commercial use may threaten existing mesquites on the monument despite the recent (and likely temporary) rise in the level of the groundwater (Sprouse et al. 2002). Groundwater pumping can also lead to subsidence that threatens the Casa Grande structure itself (NPS 1998, Richardson 2002, Hubbard et al. 2003).

\section{Non-native and Pest Species}

Awareness of non-native species as a management issue has increased in recent years; ecologists have ranked this issue as one of the most significant causes of species endangerment (Brooks and Pyke 2001). Non-native plant species are a significant management issue at the monument because it is surrounded by roads, agricultural fields, and development, which generally provide ideal conditions for the dispersal and establishment of some non-native plants. Non-native plants are known to alter ecosystem function and processes (Naeem et al. 1996, D'Antonio and Vitousek 1992) and reduce abundance of native species, creating potentially permanent changes in species diversity and community composition (Bock et al. 1986, D'Antonio and Vitousek 1992, OTA 1993). The Casa Grande and associated structures provide habitat for many non-native birds such as house sparrow and European starling (Chapter 5), and the adjacent developments provide a source for free-roaming and feral cats and dogs (Chapter 6).

In its Integrated Pest Management Plan (IPM; NPS 1997), monument personnel identified a number of wildlife species that are causing significant damage to the archaeological ruins in the monument. The IPM plan, along with that by Swann et al. (1994) identified round-tailed ground squirrel, rock pigeon, and house finch as the most important pest species. 


\section{Chapter 3: Plant Inventory}

\section{Previous Research}

The earliest collecting effort at the monument was from 1939 to 1942 when Natt Dodge, the regional naturalist, and Francis Elmore, a park ranger, collected plants from throughout the monument. These specimens (43 species) are at the University of Arizona Herbarium (Appendix A).

Reichhardt (1992) conducted an inventory of plants at the monument in 1987. This work included a list of plants that she collected, classification of vegetation communities in the monument, creation of a checklist of nonornamental plants, establishment of vegetation plots and sampling results, mapping of mesquite trees, and establishment of "photo points" for use in describing qualitative changes in the vegetation community. Halvorson and Guertin (2003) mapped the distribution of select nonnative plant species in the monument from the fall of 1999 to the spring of 2001. Collections of plants from the monument made by additional observers have been accessioned to the herbarium at the University of Arizona and to the Western Archaeological Conservation Center in Tucson (Appendix A). Finally, we conducted vegetation sampling at plots associated with stations for VCP bird surveys (see Chapter 5 for methods and Appendix M for results).

The excellent work that preceded our effort reduced the field work required for the inventory. Below-average monsoon rains in 2002 further limited our efforts because most of the species that we hoped to record are annuals that germinate following good rains.

\section{Methods}

We used "general botanizing" surveys at the monument, during which observers walked throughout the monument and opportunistically collected and recorded plants. In addition to our own results, we present here the first synthesis of findings from past studies and collections. For simplicity, we refer to all subspecies and varieties $(n=5)$ as species.

\section{Spatial Sampling Design}

Our survey crews walked throughout most of the monument on each visit.

\section{General Botanizing}

\section{Field Methods}

Whenever possible we collected one representative specimen (with reproductive structures) for each plant species. We also maintained a list of species observed but not collected. This list, along with the list of collected species, comprise a "flora" for the monument (Appendix A). When we collected a specimen we recorded the flower color, associated dominant vegetation, date, collector name(s), and UTM coordinates. We pressed the specimens on site. Specimens remained pressed for 2-3 weeks and were frozen for 48 hours to prevent infestation by insects and pathogens. We then mounted the specimens and accessioned them into the University of Arizona Herbarium.

\section{Effort}

We made three day-long visits (typically with two observers) on 21 and 22 March 2001 and 24 September 2002.

\section{Analysis}

We present summary statistics regarding number of species found and number of non-native species.

\section{Results and Discussion}

We recorded 60 species during our three visits to the monument, including 21 species that had not been previously documented in the monument (Appendix A). We collected 12 non- 


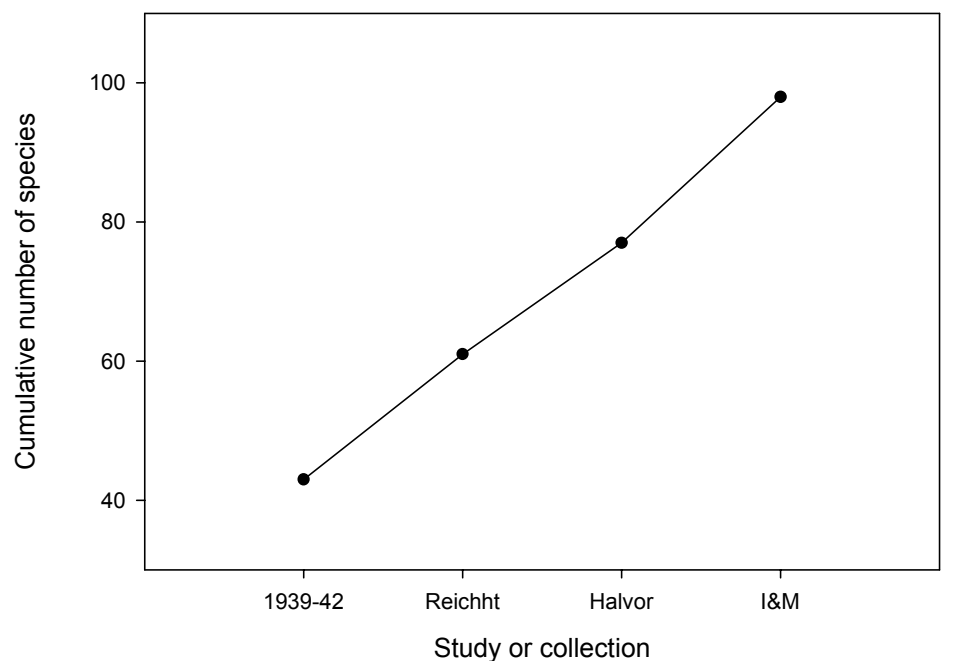

Figure 3.1. Cumulative number of new plant species found at Casa Grande Ruins NM by four separate studies or collections, from earliest collection to the most recent. "1939-42" = collection in University of Arizona Herbarium; "Reichht" = Reichhardt (1992); "Halvor" = Halvorson and Guertin (2003); "I\&" = this survey effort. (Figure should not be used as an estimate of the current species richness at the monument.)

native species, all of which had been previously recorded in the monument.

We summarized data from two previous studies (Reichhardt 1992, Halvorson and Guertin 2003) and from relevant records in the collections of two herbaria (University of Arizona and Western Archaeological Conservation Center) (Appendix A). Combining data from all studies and collections, including our own, there have been 127 species of plants recorded on or adjacent to the monument. This number includes cultivated trees, but not cultivated shrubs and succulents (e.g., ocotillo) around the visitor center (see Reichhardt [1992] for an explanation). There have been 31 species of non-native plants observed or documented at the monument (24\% of total flora), and of these, nearly $40 \%(n=12)$ are grasses (family Poaceae, Appendix A).

Reichhardt (1992) did not quantify effort associated with her surveys, but dated specimens indicate that she collected plants on four days in the winter and spring of 1987 (1 February,
1 and 17 March, and 9 June). Precipitation was below average for two years prior to Reichhardt's surveys (WRCC 2004), and this factor, in combination with greater search effort, may explain why the combined results of our inventory effort and surveys Halvorson and Guertin (2003) recorded a relatively high number of previously unrecorded species $(n=37$ species, 12 of which are non-native; Fig. 3.1).

Alternatively, these additional species may result from a marked change in the plant community that appears to have occurred over the last 15 years. ${ }^{1}$ Indeed, of the 22 non-native species that Halvorson and Guertin (2003) mapped, 16 were found only along roads and/or the irrigation canal, and an additional three species were found primarily along the monument's roads. New species were detected throughout their study. There were 52 species, including six non-natives, found by prior studies but not by our crews or by Halvorson and Guertin

${ }^{1}$ See Chapter 2 for additional information on temporal changes in the monument's vegetation community. 
(2003) (Appendix A), suggesting substantial shifts in vegetation composition and increased non-native occurrence during the last 60 years. The list of plants that have not been found since 1942 includes three species of shrubs (Alkali goldenbush, fairyduster, and eastern Mojave buckwheat).

Vehicles and roads may be enhancing the dispersal and establishment of new species, particularly non-native species (Seabloom et al. 2003). Increased precipitation runoff from roads may contribute to this apparent pattern (i.e., seeds are more likely to germinate in areas receiving more moisture), and soils along the monument boundary and roads are more likely to be disturbed (facilitating seed germination and plant establishment) than are soils in the monument interior.

\section{Inventory Completeness}

We believe that the combined effort of our study and previous studies and collections have recorded virtually all of the perennial plant species that occur at Casa Grande Ruins NM (excluding ornamentals around the visitor center). The list of annuals, however, is likely incomplete, due in part to the increasing number of nonnative plants that are becoming established in the monument (Halvorson and Guertin 2003). Each study at the monument, including ours, has recorded from 11 to 21 species that were not reported by any previous effort (Appendix A; Fig. 3.1). Because most of the new species for the monument are annual forbs and grasses, these numbers highlight the importance of surveying following periods of above-normal precipitation (as we did in 2001) and to survey repeatedly. 


\section{Chapter 4: Amphibian and Reptile Inventory}

\section{Previous Research}

To our knowledge, there has been no inventory and there is scant research related to amphibians and reptiles ("herpetofauna") at Casa Grande Ruins NM, though we located three specimens collected from the monument (Appendix H) and know of several others collected in the area or region (Appendices E, J). Charles Conner, a biologist at Organ Pipe Cactus National Monument, has surveyed diurnal lizard populations at CAGR for several years, but to date only a species list has been produced (Charles Conner, pers. comm.).

\section{Methods}

We surveyed for herpetofauna in 2001 and 2002 using four methods representing plot-based and more flexible non-plot-based methods (Table 4.1). Plot-based methods are constrained by time and area, and thus provide data for estimates of relative abundance that should be unbiased by these factors. Random location of these surveys also allows inference out to the current monument boundaries. Non-plot-based surveys allow observers more flexibility in adjusting their search time, intensity, and location, and this flexibility is important for detecting rare, elusive, or ephemeral species more likely to be missed using plot-based surveys. We used both diurnal and nocturnal surveys in an effort to detect species with restricted periods of activity (see Ivanyi et al. 2000, Stebbins 2003). We considered amphibians and reptiles together in this chapter as we used the same search methods for both groups.

\section{Spatial Sampling Designs}

For all methods except intensive surveys, we surveyed for herpetofauna in non-random sites because our primary goal was detection of the maximum number of species. To assign locations for intensive survey plots, we used ArcView software to divide the monument into 48 4-ha $(200 \mathrm{~m} \times 200 \mathrm{~m})$ plots, arranged into eight rows (east-west) and six columns (north-south). We surveyed a randomly selected subset of these plots (Fig. 4.1).

\section{Intensive Surveys}

In 2001 and 2002 we conducted searches that were constrained by both time and area to provide the most standardized survey method possible. These were visual encounter surveys (Crump and Scott 1994), limited in duration (1.5 hours) and area (4 ha).

\section{Field Methods}

We navigated to the predetermined plot corners using Garmin eMap GPS units. Vegetation and soil characteristics of the area were then described. Before and after each survey we

Table 4.1. Amphibian and reptile survey effort by method, Casa Grande Ruins NM, 2001 and 2002.

\begin{tabular}{|c|c|c|c|c|c|}
\hline \multirow[b]{2}{*}{ Survey type } & \multicolumn{2}{|c|}{2001} & \multicolumn{2}{|c|}{2002} & \multirow[b]{2}{*}{$\begin{array}{c}\text { Total survey } \\
\text { hours }\end{array}$} \\
\hline & $\begin{array}{c}\text { \# Survey } \\
\text { units }^{\mathrm{a}}\end{array}$ & Survey hours & $\begin{array}{c}\text { \# Survey } \\
\text { units }^{\mathrm{a}}\end{array}$ & $\begin{array}{l}\text { Survey } \\
\text { hours }\end{array}$ & \\
\hline Intensive survey - morning & 24 & 36.0 & 6 & 9.0 & 44.8 \\
\hline Intensive survey - evening & 5 & 2.5 & 0 & 0 & 2.5 \\
\hline Extensive survey - evening ${ }^{b}$ & 18 & 47.3 & 3 & 5.5 & 52.9 \\
\hline Pitfall trap & 18 & 234.5 & 7 & 80.2 & 314.7 \\
\hline Road & 1 & 0.6 & 1 & 0.7 & 1.3 \\
\hline
\end{tabular}

${ }^{a}$ Number of plots for intensive surveys, survey routes for extensive surveys, road surveys, or trapping sessions for pitfall traps. See text for number of visits.

${ }^{b}$ Extensive surveys were in the evening (including crepuscular period) only. 


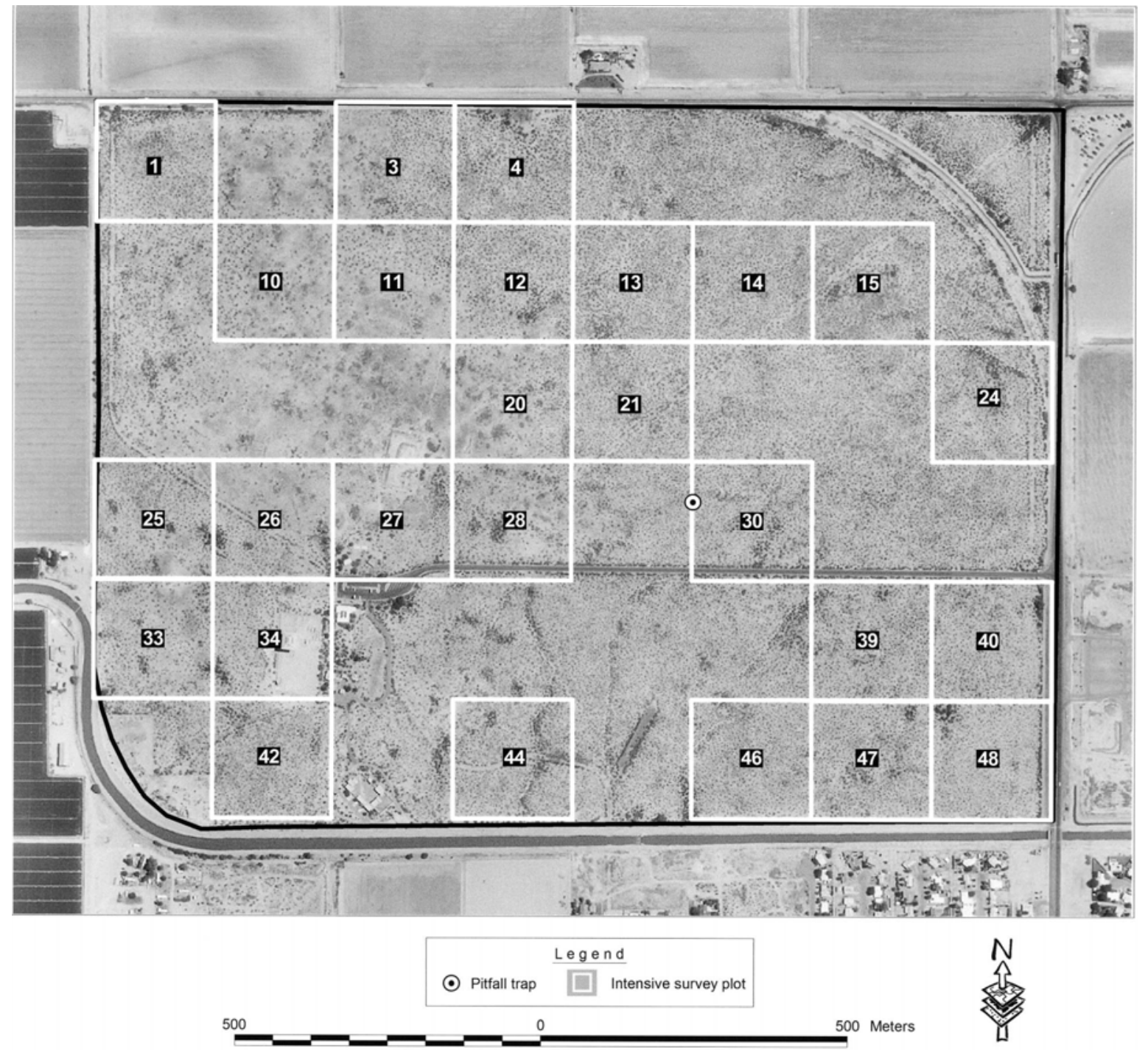

Figure 4.1. Location of intensive survey plots and pitfall-trap array for amphibians and reptiles, Casa Grande Ruins NM, 2001 and 2002.

recorded weather information: temperature $\left({ }^{\circ} \mathrm{C}\right)$, relative humidity (\%), cloud cover (\%), and wind speed $(\mathrm{km} / \mathrm{h})$. During surveys we used Garmin eMap GPS units to ensure that we stayed within the plot and each survey was systematic and nonoverlapping so that animals were not counted more than once. At each detection we recorded species, sex, and age class - adult or juvenile (if known). We finished morning surveys between 9:00 a.m.. and 12:30 p.m. during the spring (April and May), and between 8:00 a.m. and 10:00 a.m. in the summer (July and August) because lizard activity declined with higher temperatures later in the day. Evening surveys were initiated between 6:30 p.m. and 7:30 p.m.

\section{Effort}

In April and May 2001 we completed morning visits to 17 plots, and we returned in August to complete six morning visits and five evening visits. We completed an additional six morning visits in July 2002. In total, we visited: 18 plots once each in the morning, three plots once each in the morning and evening, two plots twice in the 
morning, and two plots twice in the morning and once in the evening. Each survey was completed by a single observer. For this report we express effort as number of surveys because all surveys were for the same length of time.

\section{Analysis}

We calculated relative abundance as the mean number of individuals detected per survey across all surveys. We calculated species richness as the number of species observed in each year, across all surveys.

\section{Extensive Surveys}

Extensive surveys, a type of visual-encounter survey (Crump and Scott 1994), differed from intensive surveys in that they were not constrained by area or time. We used extensive surveys to search areas that were larger than intensive survey plots, and to provide the flexibility to spend a variable amount of time searching areas of interest (e.g., shallow depressions that may form temporary pools after rains). We completed these surveys during the cooler evening and nighttime periods to maximize our chances of encountering snakes and amphibians that would be active during these times (Ivanyi et al. 2000).

\section{Field Methods}

These surveys began after 5:00 p.m., typically including the crepuscular period. Search times for each extensive survey varied from approximately 15 minutes to five hours (mean $=2.4$ hours, $\mathrm{SD}=1.4$ ) depending on conditions and logistical constraints. Before and after each survey we recorded weather information: temperature $\left({ }^{\circ} \mathrm{C}\right)$, relative humidity $(\%)$, cloud cover $(\%)$, wind speed $(\mathrm{km} / \mathrm{h})$, and an overall description of the conditions. For each animal observed, we recorded species, and sex, and age class (if known). During surveys we periodically recorded UTM coordinates (using Garmin eMap units) to define the boundaries of our search area or the path that we followed.
Effort

We spent 53 hours on 22 extensive surveys in April and August 2001, and in July 2002 (Table 4.1). All but two surveys were completed by a single observer; on these two surveys an inexperienced volunteer accompanied the crew member. Units of effort represent hours of surveying, all but two surveys of which were person-hours.

\section{$\underline{\text { Analysis }}$}

We calculated relative abundance as the mean number of individuals detected per person-hour across all surveys. We calculated species richness as the number of species observed in each year, across all surveys.

\section{Pitfall-trap Array}

Pitfall traps are a live-trap, passive sampling technique useful in detecting species that would be difficult to observe because of rarity, limited activity periods, or inconspicuous behavior (Corn 1994).

\section{Field Methods}

We constructed a pitfall trap array by placing three 19-L buckets roughly $8 \mathrm{~m}$ away and at angles of approximately 120 degrees each from a central bucket (Gibbons and Semlitsch 1981). We dug shallow trenches between buckets in which we placed drift fences (7.6-m long, 0.5-m tall aluminum flashing supported with rebar) that connected each of the three outside buckets to the central bucket. Buckets were buried so that the lip was at ground level. We placed cover boards (50 x $50 \mathrm{~cm}$ pieces of plywood) over the buckets to keep the animals cool during the day, minimize mortality, and attract additional animals (Corn 1994).

In an attempt to capture large snakes and other animals that are able to escape from pitfall trap buckets (Corn 1994), we placed one wiremesh funnel trap (tubes with inwardly-directed cones at each end) at the midpoint along each side of the drift fences (total of six funnel traps). Animals entering via the funnels would fall to 
the bottom of the tube and be unable to escape. We typically opened the pitfall and funnel traps around sunset, then checked and closed the traps the next morning. For each animal captured, we recorded species, sex, and age class (if known).

\section{Effort}

We established one pitfall trap array (with four pitfall traps and six funnel traps) north of the entrance road (Fig. 4.1). We operated the array for a total of 315 hours from July to September 2001, and in July 2002 (Table 4.1).

\section{Analysis}

We report the number of animals captured per 100 hours of pitfall array operation.

\section{Road Surveys}

Driving slowly on roads at night is recognized as an excellent method for surveying some groups of reptiles, particularly nocturnal snakes (e.g., Rosen and Lowe 1994). Before and after each survey we recorded weather information: temperature $\left({ }^{\circ} \mathrm{C}\right)$, relative humidity $(\%)$, cloud cover $(\%)$, and wind speed $(\mathrm{km} / \mathrm{h})$. For each amphibian and reptile observed, we recorded species, sex and age class (if known), the mileage from the start point of the survey, and whether the animal was alive or dead. We surveyed the entrance road and dirt roads along the south and west monument boundaries with this method.

\section{Effort}

We completed two surveys (one each year) totaling 1.3 hours of effort (Table 4.1).

\section{Analysis}

We report the number of animals seen during both surveys.

\section{Coverboards}

To increase the odds of finding animals, we placed 10 "cover boards" $(0.5 \times 0.5 \mathrm{~m}$ plywood squares which could be used as cover by animals; Fellers and Drost 1994) on both the north- and south-side of the main entrance road, east of the visitor center. We set out the cover boards in April 2001 and collected them at the end of the field season in 2002. We checked underneath cover boards occasionally during extensive surveys.

\section{Incidental Observations}

When we encountered amphibians and reptiles outside of formal surveys, we recorded the species, sex and age class (if known), time of observation, UTM coordinates, and route we were following.

\section{Results}

We recorded three amphibian and 11 reptile species at Casa Grande Ruins NM (Appendix B). Common side-blotched and western whiptail lizard were the two most abundant species, and together they represented $>75 \%(n=670$ of 877 ) of all detections across all survey methods (Tables 4.2-4.4).

\section{Intensive Surveys}

We recorded seven species of reptiles during intensive surveys (Table 4.2). The common sideblotched and western whiptail lizards were the most abundant diurnal lizards in both years, and the common side-blotched was the only lizard recorded on nocturnal intensive surveys. We encountered few snakes during these surveys (3 species), and only the gopher snake was recorded on more than one occasion (Table 4.2). We did not record any amphibians during intensive surveys.

\section{Extensive Surveys}

During extensive surveys we recorded 13 species, which included all but one of the species (Great Plains toad, detected during road surveys) that we detected with all methods combined (Tables 4.24.4). The western banded gecko and the common side-blotched lizard were the most abundant reptile species found during extensive surveys, though the long-nosed snake was similarly 
Table 4.2. Total number of observations $(n)$ and relative abundance (mean and SE) of reptiles ${ }^{\mathrm{a}}$ recorded during intensive surveys, Casa Grande Ruins NM, 2001 and 2002.

\begin{tabular}{|c|c|c|c|c|c|c|c|}
\hline \multirow[b]{3}{*}{ Common name } & \multirow[b]{3}{*}{$n$} & \multicolumn{4}{|c|}{2001} & \multicolumn{2}{|c|}{2002} \\
\hline & & \multicolumn{2}{|c|}{ Morning } & \multicolumn{2}{|c|}{ Evening } & \multicolumn{2}{|c|}{ Evening } \\
\hline & & Mean & SE & Mean & SE & Mean & SE \\
\hline desert spiny lizard & 5 & 0.1 & 0.07 & \multirow{5}{*}{0.4} & \multirow{3}{*}{0.24} & 0.3 & 0.33 \\
\hline common side-blotched lizard & 252 & 8.6 & 1.51 & & & 8.7 & 2.69 \\
\hline long-tailed brush lizard & 19 & 0.7 & 0.20 & & & 0.5 & 0.50 \\
\hline western (tiger) whiptail & 330 & 7.7 & 1.52 & & & 25.3 & 6.01 \\
\hline gopher snake & 2 & $<0.1$ & 0.06 & & & & \\
\hline long-nosed snake & 1 & \multirow{4}{*}{$\begin{array}{l}<0.1 \\
<0.1 \\
2.2 \\
\end{array}$} & & \multirow[t]{4}{*}{0.2} & 0.20 & \multirow{4}{*}{$\begin{array}{l}0.2 \\
1.5\end{array}$} & \\
\hline Mojave rattlesnake & 1 & & 0.04 & & & & \\
\hline unknown snake & 1 & & 0.04 & & & & 0.17 \\
\hline unknown lizard & 59 & & 0.45 & & & & 0.76 \\
\hline Species richness & 7 & \multicolumn{2}{|c|}{6} & \multicolumn{2}{|c|}{2} & \multicolumn{2}{|c|}{1} \\
\hline Total no. detections & 671 & \multicolumn{2}{|c|}{449} & \multicolumn{2}{|c|}{3} & \multicolumn{2}{|c|}{219} \\
\hline
\end{tabular}

${ }^{a}$ No amphibians were recorded during intensive surveys.

${ }^{\mathrm{b}}$ Glimpsed before identification could be made.

Table 4.3. Total number of observations ( $n$ ) and relative abundance (mean and SE) of reptiles $^{\mathrm{a}}$ recorded during intensive surveys, Casa Grande Ruins NM, 2001 and 2002.

\begin{tabular}{|c|c|c|c|c|c|c|c|}
\hline \multirow[b]{3}{*}{ Common name } & \multirow[b]{3}{*}{$n$} & \multicolumn{4}{|c|}{2001} & \multicolumn{2}{|c|}{2002} \\
\hline & & \multicolumn{2}{|c|}{ Morning } & \multicolumn{2}{|c|}{ Evening } & \multicolumn{2}{|c|}{ Evening } \\
\hline & & Mean & SE & Mean & SE & Mean & $\mathrm{SE}$ \\
\hline desert spiny lizard & 5 & 0.1 & 0.07 & & & 0.3 & 0.33 \\
\hline common side-blotched lizard & 252 & 8.6 & 1.51 & 0.4 & 0.24 & 8.7 & 2.69 \\
\hline long-tailed brush lizard & 19 & 0.7 & 0.20 & \multirow{7}{*}{0.2} & & \multirow{4}{*}{$\begin{array}{c}0.5 \\
25.3\end{array}$} & 0.50 \\
\hline western (tiger) whiptail & 330 & 7.7 & 1.52 & & & & 6.01 \\
\hline gopher snake & 2 & \multirow[t]{2}{*}{$<0.1$} & 0.06 & & & & \\
\hline long-nosed snake & 1 & & & & 0.20 & & \\
\hline Mojave rattlesnake & 1 & $<0.1$ & 0.04 & & & \multirow{3}{*}{$\begin{array}{l}0.2 \\
1.5\end{array}$} & \\
\hline unknown snake & 1 & $<0.1$ & 0.04 & & & & 0.17 \\
\hline unknown lizard ${ }^{b}$ & 59 & 2.2 & 0.45 & & & & 0.76 \\
\hline Species richness & 7 & \multicolumn{2}{|c|}{6} & \multicolumn{2}{|c|}{2} & \multicolumn{2}{|c|}{4} \\
\hline Total no. detections & 671 & \multicolumn{2}{|c|}{449} & \multicolumn{2}{|c|}{3} & \multicolumn{2}{|c|}{219} \\
\hline
\end{tabular}

${ }^{a}$ No amphibians were recorded during intensive surveys.

${ }^{b}$ Glimpsed before identification could be made.

Table 4.4. Total number of observations $(n)$ and relative abundance (mean and SE) of reptiles and amphibians recorded during extensive surveys, Casa Grande Ruins NM, 2001 and 2002.

\begin{tabular}{|c|c|c|c|c|c|c|}
\hline \multirow[b]{2}{*}{ Group } & \multirow[b]{2}{*}{ Common name } & \multirow[b]{2}{*}{$n$} & \multicolumn{2}{|c|}{2001} & \multicolumn{2}{|c|}{2002} \\
\hline & & & Mean & SE & Mean & SE \\
\hline \multirow[t]{2}{*}{ Amphibian } & Couch's spadefoot & 30 & & & 10.0 & 4.73 \\
\hline & Sonoran desert toad & 14 & 0.6 & 0.25 & 1.0 & 0.58 \\
\hline \multirow[t]{12}{*}{ Reptile } & western banded gecko & 22 & 1.0 & 0.52 & 1.0 & 0.58 \\
\hline & desert spiny lizard & 4 & 0.2 & 0.12 & 0.3 & 0.33 \\
\hline & common side-blotched lizard & 57 & 2.7 & 1.70 & 2.0 & 2.00 \\
\hline & long-tailed brush lizard & 2 & 0.1 & 0.11 & & \\
\hline & western whiptail & 14 & 0.7 & 0.44 & & \\
\hline & coachwhip & 2 & & & 0.7 & 0.67 \\
\hline & gopher snake & 2 & $<0.1$ & 0.05 & 0.3 & 0.33 \\
\hline & common kingsnake & 1 & $<0.1$ & 0.05 & & \\
\hline & long-nosed snake & 21 & 1.0 & 0.24 & 0.7 & 0.67 \\
\hline & western diamond-backed rattlesnake & 1 & $<0.1$ & 0.05 & & \\
\hline & Mojave rattlesnake & 4 & 0.2 & 0.09 & 0.3 & 0.33 \\
\hline & unknown lizard & 4 & 0.1 & 0.11 & 0.7 & 0.67 \\
\hline \multicolumn{2}{|c|}{ Species richness } & (178) & \multicolumn{2}{|c|}{11} & \multicolumn{2}{|c|}{10} \\
\hline
\end{tabular}


abundant in 2001 (Table 4.3). We recorded more Couch's spadefoot toads than any other species in 2002, though this was clearly associated with monsoon rains; all but one of the Couch's spadefoot toads were recorded during one postrain survey in July.

\section{Road Surveys, Pitfall Traps, Incidental Observations, and Coverboards}

We added one new species to the monument list with the road survey method (Great Plains toad; Tables 4.2-4.4); in fact we observed all three of the amphibian species recorded by our inventory during one night of road survey in 2002. Although the pitfall trap did not contribute additional species to our monument list, results from the trap were consistent with other methods and suggest that common side-blotched and western whiptails are among the most common lizards at the monument (Table 4.4). Incidental detections did not add any species to our lists, but this method did add records for species that were seldom detected by other methods, notably
Couch's spadefoot, coachwhip, and common kingsnake. We found no animals underneath coverboards.

\section{Inventory Completeness}

It is seems unlikely that we missed several conspicuous species that we would expect to find at the monument: zebra-tailed lizard, desert iguana, long-nosed leopard lizard, and sidewinder. Rosen (Appendix J) attributes the lack of recent records for these species to habitat fragmentation and altered vegetation. Species likely present in the monument that we did not detect include snakes that are nocturnal and inconspicuous (and in some cases, fossorial) such as: western blind snake, spotted leaf-nosed snake, saddled leaf-nosed snake, glossy snake, western ground snake, western shovel-nosed snake, and night snake (Appendix E, J; Stebbins 2003). We received an unconfirmed report of a western shovel-nosed snake (Karen Monroe, pers. comm.). This highlights that confirming

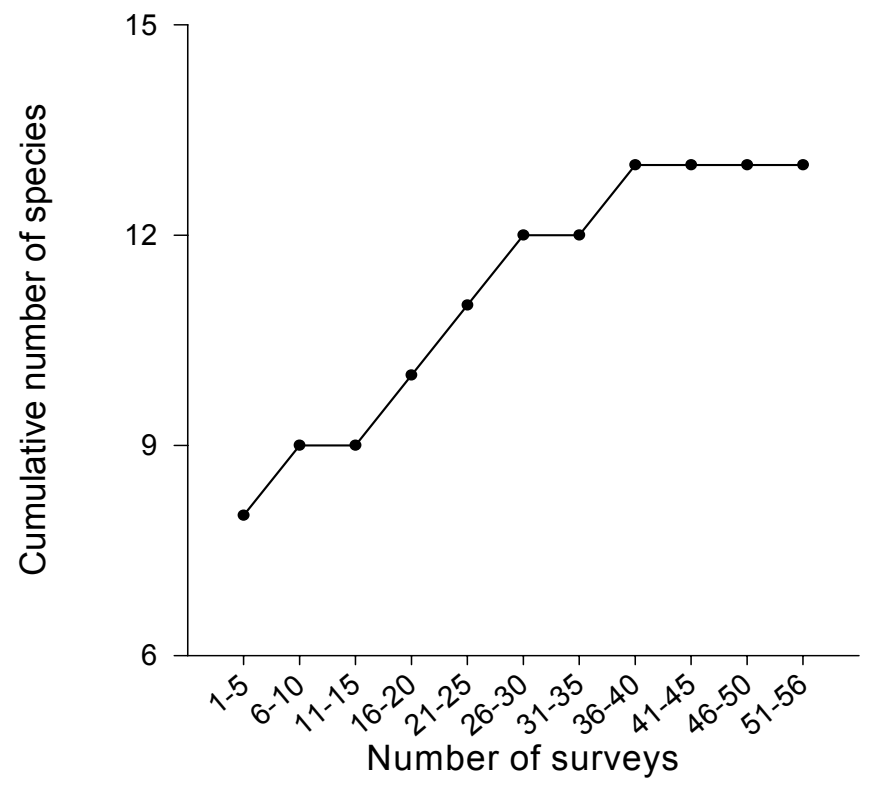

Figure 4.2. Species accumulation curve for intensive and extensive amphibian and reptile surveys, Case Grande Ruins NM, 2001 and 2002. Survey order was randomized to account for differences in animal activity patterns. 
the potential presence of these inconspicuous species may require substantial field effort by experienced personnel or documentation (voucher by collection or photograph) by other observers.

We believe that our inventory detected fewer than $90 \%$ of the amphibians and reptiles present simply because reaching this goal would only require finding one more amphibian or two more reptile species. A species accumulation curve for intensive and extensive surveys appears to show that the number of new species reaches an asymptote after our 56 surveys (Fig. 4.2), and indicates that we recorded most of the species likely to be observed with these methods, at least under the environmental conditions (e.g., belowaverage precipitation) during our study. Note also the dominance of the most common species at the monument; $>60 \%$ of the species $(n=8$ of 13 species) that we recorded with these surveys were detected within the first five surveys ${ }^{1}$ and only one new species was detected in the last 26 surveys (Fig. 4.2).

\section{Discussion}

The amphibian and reptile communities at Casa Grande Ruins NM comprise relatively few species in comparison to what was likely present historically (Appendix J) or in comparison to what has been documented in the course of other recent herpetofauna inventories in management units of similar size in southern Arizona (e.g., Rosen and Mauz 2001, Powell et al. 2002, Powell et al. 2003, Powell et al. 2004). This low species richness likely results from the land uses in the vicinity of the monument (see Chapter 2) and degradation of the nearby Gila River (i.e., loss of aquatic and riparian resources; McNamee 1994, Ingram 2000).

The common side-blotched lizard and western whiptail lizard were the most abundant species we detected in the monument (Tables 4.2-4.4), though the number of animals and species recorded appears to differ with activity period. This pattern is most evident in the results

\footnotetext{
${ }^{1}$ See Chapter 1 ; note that surveys are not plotted in
} chronological order. from intensive surveys, which are the most appropriate method for inferring abundance due to their random placement. Observations of western whiptail and common side-blotched lizards decreased in the cooler evening and nighttime periods while observations of western banded geckos increased, a pattern that is consistent with the known behavioral characteristics of these species (Ivanyi et al. 2000, Stebbins 2003). Several species of snakes and toads contribute to a nocturnally active community that is more diverse than the diurnally active community (Tables 4.2-4.4). Although our primary active survey methods for diurnal species (intensive surveys) and nocturnal species (extensive surveys) are not directly comparable because of differences in methodology, the general patterns we observed were substantiated by results from other methods (pitfalls, road, and nocturnal intensive surveys) and life-history characteristics.

Species observed in this study would be expected to occur on the monument due to the environmental characteristics present in the area. Lizards in this area are associated with creosote flats and/or sparse vegetation, and the snakes are primarily generalists (Ivanyi et al. 2000, Stebbins 2003). The common lizards, in particular, are characteristic of the Lower Colorado Valley, while the generalist snakes represent those found abundantly in both the Lower Colorado Valley and Arizona Upland (Mojave rattlesnake and gopher snake) and those that are generally more abundant in the Arizona Upland province of the Sonoran Desert (long-nosed snake and western diamond-backed rattlesnake); however, characteristic Lower Colorado Valley forms, such as the western shovel-nosed snake, spotted night snake, and sidewinder were not observed (Appendix J).

Historically, the area around the monument was biologically diverse because it is situated at the edge of the Lower Colorado Valley province in the mesic transition towards Arizona Uplands, with the Gila River (and pre-historic network of canals) nearby (Appendix J). Over the last century, however, this area has undergone dramatic change including elimination of perennial flow in the adjacent Gila River; 
associated cienegas and riparian vegetation have disappeared as a result (McNamee 1994, Ingram 2000). Other changes include agriculture, urban development, and road construction, and associated effects (see Chapter 2).

In a review of specimen records from the lowland desert flats around Casa Grande Ruins NM (roughly bounded by the communities of Maricopa, Queen Creek, Florence Junction, Florence, and Casa Grande), Rosen lists 40 species that have been documented and an additional ten species that are possible in the area (Appendix E). Rosen (2004) suggested that (1) because many of these species are associated with riparian conditions, they may have been extirpated when the Gila River flows were reduced and (2) additional species associated with Arizona Uplands (saddled leafnosed snake, variable sand snake, southwestern black-headed snake, regal horned lizard, and ornate tree lizard) were likely present in the area of Casa Grande Ruins NM, primarily due to proximity of Arizona Uplands, and so may also have been extirpated from the area. While species that are associated with riparian areas are not likely remaining in the monument, it should be noted that the current system of irrigation canals adjacent to the monument might provide connectivity with surrounding areas. Although the canal water moves too quickly to support most aquatic species (e.g., Sonoran mud turtle), some large snakes (e.g., western diamond-backed rattlesnake) are known to swim (Degenhardt et al. 1996) and may use the canals to move across the landscape. In the absence of this "corridor" these species might not persist (or might be less abundant) in the monument. In Phoenix and near Picacho, Sonoran mud turtles, ranid frogs, and checkered garter snakes are known to use irrigation and other canals. In relatively small xeroriparian patches associated with major canals in Florence, the banded sand snake, southwestern black-headed snake, and tree lizard were all abundant at least into the mid-1990s, and probably still persist today (Rosen, pers. comm.).

\section{Notes on Venomous Reptiles}

It should be noted that although we recorded two species of poisonous snake at Casa Grande Ruins NM (for the total of six rattlesnake observations, many of which may have been the same individuals), these were the result of over 100 hours of searching by trained herpetologists. Therefore, these snakes are sufficiently rare to pose a limited threat to visitors. Furthermore, the majority of reptile bites reported to Tucson's Arizona Poison and Drug Information Center were provoked by the victim (e.g., harassment or attempt to handle) and even then, chances of death following a reptile bite are less than one percent (APDIC 2003). 


\section{Chapter 5: Bird Inventory}

\section{Previous Research}

To our knowledge scant bird research has taken place at Casa Grande Ruins NM since a limited-scope banding study in the 1930s (Fast 1936). Barry (1987) created a checklist for the monument, but no source material exists and so we do not consider it here. There are two Breeding Bird Survey routes located approximately 5 and $10 \mathrm{~km}$ west of the monument (Sauer et al. 2004): "Cactus Forest" was surveyed in 1991, 1993, and 1996-2002; "Coolidge" transect was surveyed 1974-1985. We found no records of specimens collected from the monument (Appendix H).

\section{Methods}

We surveyed for birds in the monument in 2001 and 2002. We used four field methods: variable circular-plot counts for diurnal breeding birds, nocturnal surveys for owls and nightjars, line transects for over-wintering birds, and incidental observations for all birds in all seasons. Although winter bird surveys were not included in the original study proposal (Davis and Halvorson 2000), we felt they were important in our effort to inventory birds at the monument because many species that use the area during the fall and winter may not be present during spring and summer (breeding season) surveys. We concentrated our primary survey effort during the breeding season because bird distribution is relatively uniform at this time (due to territoriality among most landbird species; Bibby et al. 2002), which increased our precision in estimating relative abundance and also enabled us to document breeding activity. Our survey period included peak spring migration times for most species, which added many migratory species to our list.

We also sampled vegetation around VCP survey stations. Vegetation structure and plant species composition are important predictors of bird species richness or the presence of particular species (MacArthur and MacArthur 1961, Rice et al. 1984, Strong and Bock 1990, Powell and Steidl 2000).

\section{Spatial Sampling Designs}

We subjectively located all survey stations and transect sections, but because of the monument's small size and relatively homogenous vegetation, our sampling achieved nearly complete coverage of the monument (Fig. 5.1).

\section{VCP Surveys: Breeding Season}

\section{Field Methods}

We used the variable circular-plot method to survey for diurnally active birds during the breeding season (VCP; Reynolds et al. 1980, Buckland et al. 2001). Conceptually, these surveys are similar to traditional "point counts" (Ralph et. al 1995) during which an observer spends a standardized length of time at one location (i.e., station) and records all birds seen or heard and the distance to each bird or group of birds.

We established one transect in 2001 that consisted of 12 stations, but reduced the number of stations to eight in 2002 because of the difficulty in surveying 12 stations in a single morning. Stations along each transect were located a minimum of $250 \mathrm{~m}$ apart to maintain independence among observations at each station. Each year we surveyed from mid April through mid June, the period of peak breeding activity for most species in southern Arizona. We visited each station at least four times per season. On each visit we alternated observers and the order in which we surveyed stations (along a transect) to minimize bias by observer, time of day, and direction of travel. We began bird surveys approximately 30 minutes before sunrise and concluded no later than four hours after sunrise, or when bird activity decreased markedly. We did not survey when wind exceeded $15 \mathrm{~km} / \mathrm{h}$ or when precipitation exceeded an intermittent drizzle. 


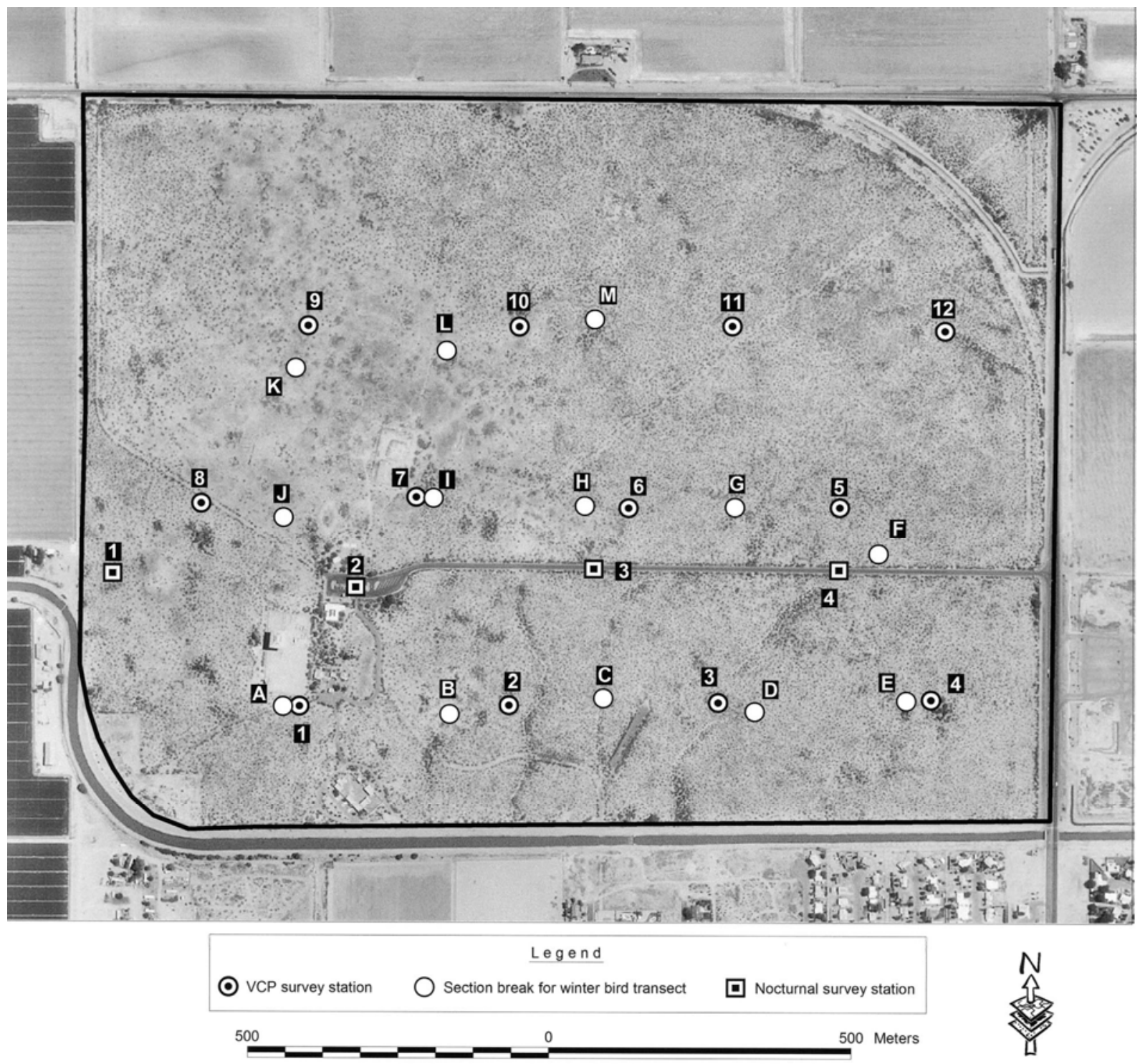

Figure 5.1. Location of VCP survey stations and line-transect sections (winter bird transect) for birds, CasaGrande Ruins NM, 2001 and 2002.

We recorded a number of environmental variables at the beginning of each transect: wind speed (Beaufort scale), presence and severity of rain (qualitative assessment), air temperature $\left({ }^{\circ} \mathrm{F}\right)$, relative humidity (\%), and cloud cover (\%). After arriving at a station, we waited one minute before beginning the count to allow birds to resume their normal activities. We identified to species all birds seen or heard during an eight-minute "active" period. For each detection we recorded distance in meters from the observer (measured with laser range finder when possible), time of detection (measured in one-minute intervals beginning at the start of the active period), and the sex and/or age class (adult or juvenile), if known. We did not measure distances to birds that were flying overhead nor did we use techniques to attract birds (e.g., "pishing"). We made an effort to avoid double-counting individuals that had been recorded at previous stations. If we observed a species during the "passive" count period (between the eight-minute 
counts), which had not been recorded previously at a station on that visit, we recorded its distance to the nearest station.

\section{Effort}

We visited all 12 survey stations four times each in 2001. In 2002 we reduced the number of stations to 8 (station numbers 1, 2, and 6-11) and surveyed each of them four times. Each station was visited for 8 minutes.

\section{Analyses}

We calculated relative abundance of each species as the number of detections at all stations and visits (including zero values), divided by effort (total number of visits multiplied by total number of stations). We reduced our full collection of observations $(N=1,032)$ to a subset of data $(n=200)$ that was more appropriate for estimating relative abundance. We used only those detections that occurred $\leq 75 \mathrm{~m}$ from count stations (thereby excluding 381 observations) because detectability is influenced by conspicuousness of birds (i.e., loud, large, or colorful species are more detectable than others) and environmental conditions (dense vegetation can reduce likelihood of some detections). Truncating detections may reduce the influence of these factors (Verner and Ritter 1983; for a review of factors influencing detectability see Anderson 2001, Farnsworth et al. 2002). We also excluded observations of birds that were flying over the station (415 observations), birds observed outside of the eight-minute count period (63 observations), and unknown species (18 observations). Some observations met more than one of these criteria for exclusion from analysis.

We include relative abundance estimates for birds seen $\leq 75 \mathrm{~m}$ from stations to allow for the most meaningful comparisons among species, and (to some degree) among parks surveyed by this project (see Powell et al. 2005). However, Casa Grande Ruins NM is somewhat unique among Sonoran Desert Network parks in that observers are able to see most birds that are either flying over the monument or are perched (on either the dead mesquite trees or on nearby poles and wires that surround the monument). This unobscured view explains why $40 \%$ of the observations were flyovers and $37 \%$ of the observations were $>75 \mathrm{~m}$ from count stations. Because of the overall low density of birds (reflected in the low number of detections $\leq 75$ $\mathrm{m}$ from stations), we feel that our estimates of relative abundance convey important information about the birds at each station, but they do not convey sufficient information about the monument's bird community as a whole or put the community in the context of the surrounding landscape. For example, eliminating flyover observations means that we do not report on the hundreds of great-tailed grackles and red-winged blackbirds that fly over the monument en route to adjacent areas.

To account for this bias we calculate frequency of detections, which includes birds observed flying over the monument and those at unlimited distances from stations. Frequency of detections differs from relative abundance in that it is clearly biased toward those species that are highly visible. Therefore, it can be thought of as an index of the number of birds that we saw and heard at typical stations on the transect (i.e., most similar to an observer's "experience"). Unlike relative abundance, which allows for some comparison among species, relative frequency of detection should not be compared among species. To calculate both relative abundance and relative frequency of detection, we grouped data from all stations because of the homogeneity of vegetation in the monument.

\section{Line-transect Surveys: Non-breeding Season}

\section{Field Methods}

We used a modified line-transect method (Bibby et al. 2002) to survey for birds from October to December 2002. Line transects differ from station transects (such as those used in our VCP surveys) in that an observer records birds seen or heard while the observer walks a line, rather than stands at a series of stations. The transect method is more effective during the non-breeding season because bird vocalizations are less conspicuous and frequent, and therefore birds tend to be more difficult to detect (Bibby et al. 2002).

We established one transect at the monument. The transect was broken into sections, 
with the start and finish points corresponding to the VCP stations (Fig. 5.1). Each section was approximately $250 \mathrm{~m}$ in length. As with other survey methods, we alternated observers and direction of travel along transects to reduce biases, and did not survey during periods of excessive rain or wind (see VCP survey methods for details). We began surveys about 30 minutes after sunrise and continued until we completed the transect. As with VCP surveys, we recorded weather conditions at the beginning and end of each survey. Prior to beginning a section, we recorded the section name (e.g., "A-B") and the start time.

We timed our travel so that we traversed each section in ten minutes, during which time we assigned all birds seen and/or heard into one of the following distance categories: $\leq 100 \mathrm{~m},>$ $100 \mathrm{~m}$, or "flyover." When possible, we noted the sex and age class of birds. We recorded birds observed before or after surveys as "incidentals" (see section below), and we did not use techniques to attract birds (e.g., "pishing").

\section{Effort}

We visited all 12 sections four times in 2002 ( $n$ $=48$ ): 24 October, 8 and 25 November, and 19 December. The total time spent on each section was 10 minutes.

\section{Analysis}

Due to the low number of observations $(n=125)$ within $100 \mathrm{~m}$ of the transect lines, we used all observations $(n=173)$ except unknown species to estimate relative frequency of detections (see Methods section of VCP surveys for more details).

\section{Nocturnal Surveys}

\section{Field Methods}

To survey for owls we broadcasted commercially available vocalizations (Colver et al. 1999) using a compact disc player and broadcaster (Bibby et al. 2002), and recorded other nocturnal species (nighthawks and poorwills) when observed. We established one nocturnal survey transect that bisected the monument along the main entrance road (Fig. 5.1). The transect had four stations that were a minimum of $300 \mathrm{~m}$ apart. As with other survey methods, we varied observers and direction of travel along transects and did not survey during periods of excessive rain or wind to reduce bias. We began surveys approximately 45 minutes after sunset.

We began surveys at each station with a three-minute "passive" listening period during which time we broadcast no calls. We then broadcast vocalizations for a series of two-minute "active" periods. We used vocalizations of species that we suspected, based on habitat and range, might be present: elf, western screech, burrowing, and barn owls. We excluded the great horned owl from the broadcast sequence because of their aggressive behavior toward other owls. We also did not survey for cactus-ferruginous pygmy owls (Glaucidium brasilianum cactorum) at the monument because (1) we believe that habitat does not exist for this species and (2) targeted surveys for threatened or endangered species were not included in the study. We broadcast recordings of owls in sequence from smallest to largest size species so that smaller species would not be inhibited by the "presence" of larger predators or competitors (Fuller and Mosher 1987). During active periods, we broadcasted owl vocalizations for 30 seconds followed by a 30 -second listening period. This pattern was repeated two times for each species.

During the count period we used a flashlight to scan nearby vegetation and structures for visual detections. If we observed a bird during the three-minute passive period, we recorded the minute of the passive period in which the bird was first observed, the type of detection (aural, visual or both), and the distance to the bird. If a bird was observed during any of the two-minute active periods, we recorded in which interval(s) it was detected and the type of detection (aural, visual, or both). As with other survey types, we attempted to avoid double-counting individuals recorded at previous stations. We also used multiple observers, alternated direction of travel along transects, and did not survey during inclement weather. 
Effort

We visited each of the four nocturnal survey stations three times each in 2001 and twice each in 2002 ( $n=20$ surveys).

\section{Analysis}

We report the total number of detections for both years combined; sample sizes were inadequate for calculating meaningful estimates of relative abundance.

\section{Incidental and Breeding Observations}

\section{Field Methods}

When we were not conducting formal surveys and encountered a rare species, a species in an unusual location, or an individual engaged in a breeding behavior, we recorded UTM coordinates, time of detection, and (if known) the sex and age class of the bird. We recorded all breeding behavior observations using the standardized classification system (developed by the North American Ornithological Atlas Committee; NAOAC 1990). This system classifies breeding behavior into one of nine categories: adult carrying nesting material, nest building, adult performing distraction display, used nest, fledged young, occupied nest, adult carrying food, adult feeding young, or adult carrying a fecal sac. We made breeding observations during both standardized surveys and incidental observations.

\section{Analysis}

We report frequency counts of incidental and breeding observations; we cannot calculate relative abundance (as for VCP surveys) because we did not standardize survey effort.

\section{Vegetation Sampling at VCP Stations}

We sampled vegetation near each VCP survey station to characterize community composition and structure. These data could be used to help determine habitat associations for bird species and identify important features of species-rich communities at the monument. We sampled vegetation at five plots located at a modified- random direction and distance from each station. Each plot was located within a $72^{\circ}$ range of the compass from the station (e.g., Plot 3 was located from $145^{\circ}$ to $216^{\circ}$ ) to reduce clustering of plots. We randomly placed plots from 0 to $75 \mathrm{~m}$ from each station to correspond with truncation of bird data used in estimating relative abundance.

At each plot we used the point-quarter method (Krebs 1998) to sample vegetation by dividing the plot into four quadrants along cardinal directions. We applied this method to plants in four size categories: sub-shrubs $(0.5-1.0 \mathrm{~m})$, shrubs $(>1.0-2.0 \mathrm{~m})$, trees $(>2.0$ $\mathrm{m})$, and potential cavity-bearing vegetation ( $>$ $20 \mathrm{~cm}$ diameter at breast height). If there was no vegetation in a given category within $25 \mathrm{~m}$ of the plot center, we indicated this in the species column. For each individual plant we recorded distance from the plot center, species, height, and maximum canopy diameter (excluding errant branches). Association of a plant to a quadrant was determined by the location of its trunk, regardless of which quadrant contained the majority of the plant; no plant was recorded in $>1$ quadrant. Standing dead vegetation was only attributed to the "potential cavity-bearing tree" category. On rare occasions when plots overlapped we repeated the selection process for the second plot.

Within a 5-m radius around the center of each plot, we visually estimated (1) percent ground cover by type (bare ground, litter, or rock [loose rocks or stones]) and (2) percent aerial cover of vegetation in each quadrant using three height categories: $0-0.5 \mathrm{~m},>0.5-2 \mathrm{~m}$, and $>2 \mathrm{~m}$.

\section{Analysis}

Using point-quarter data, we calculated mean density (number of stems/ha) for all species in each of the four height/size categories using the computer program "Krebs" (Krebs 1998). We collected these data to characterize gross vegetation characteristics around some survey stations. In the event that future bird surveys detect marked changes in species or communities, the vegetation data reported in Appendix M will provide a baseline for measurement and comparison of potential explanatory variables. 


\section{Results}

We recorded 82 bird species during the two years of the study (Appendix C). Seventy one percent $(n=58)$ of the species that we observed were neotropical migrants. We observed a number of species of conservation concern: loggerhead shrike, burrowing owl, peregrine falcon, and ferruginous hawk, all of which are considered "Species of Concern" by the U.S. Fish and Wildlife Service (see Appendix C for other conservation designations). We recorded three non-native species: rock pigeon, European starling, and house sparrow.

\section{VCP Surveys}

We recorded 63 species during VCP surveys at the monument (Appendix C). Of these, we were able to estimate relative abundance for 29 species (Table 5.1). Excluding the Brewer's sparrow (for which $80 \%$ of observations were from a single day), the mourning dove was the most abundant species during this study (Table 5.1). The Gambel's quail and house sparrow were also common. By including birds that were seen flying over the monument and those seen or heard at unlimited distances from stations (see methods section), the frequency of detections for each species provides additional information on the bird community at the monument: cliff swallow and mourning dove had the highest number of detections (Table 5.2). Four commonly detected species (most often seen flying over the monument) were the rock pigeon, red-winged blackbird, great-tailed grackle, and house finch (Table 5.2).

The most widespread species, based on their presence at all 12 survey stations, were the

Table 5.1. Number of observations $(n)$ and relative abundance of birds recorded within $75 \mathrm{~m}$ of count stations from VCP surveys, Casa Grande Ruins NM, 2001 and 2002. See Methods section for details on estimation of relative abundance and effort.

\begin{tabular}{|c|c|c|c|}
\hline \multirow[b]{2}{*}{ Species } & \multirow[b]{2}{*}{$n$} & \multicolumn{2}{|c|}{ Relative abundance } \\
\hline & & Mean & SE \\
\hline Gambel's quail & 30 & 0.35 & 0.061 \\
\hline American kestrel & 1 & 0.01 & 0.012 \\
\hline mourning dove & 57 & 0.66 & 0.080 \\
\hline Inca dove & 2 & 0.02 & 0.023 \\
\hline burrowing owl & 3 & 0.03 & 0.020 \\
\hline lesser nighthawk & 5 & 0.06 & 0.030 \\
\hline black-chinned hummingbird & 9 & 0.10 & 0.044 \\
\hline Anna's hummingbird & 10 & 0.12 & 0.035 \\
\hline Costa's hummingbird & 2 & 0.02 & 0.016 \\
\hline Gila woodpecker & 2 & 0.02 & 0.016 \\
\hline gilded flicker & 4 & 0.05 & 0.028 \\
\hline western wood-pewee & 1 & 0.01 & 0.012 \\
\hline ash-throated flycatcher & 5 & 0.06 & 0.025 \\
\hline horned lark & 13 & 0.15 & 0.088 \\
\hline verdin & 11 & 0.13 & 0.036 \\
\hline cactus wren & 5 & 0.06 & 0.025 \\
\hline European starling & 1 & 0.01 & 0.012 \\
\hline yellow warbler & 1 & 0.01 & 0.012 \\
\hline MacGillivray's warbler & 1 & 0.01 & 0.012 \\
\hline Wilson's warbler & 1 & 0.01 & 0.012 \\
\hline western tanager & 1 & 0.01 & 0.012 \\
\hline chipping sparrow & 2 & 0.02 & 0.023 \\
\hline Brewer's sparrow & $87^{a}$ & 1.01 & 0.474 \\
\hline vesper sparrow & 1 & 0.01 & 0.012 \\
\hline lark sparrow & 2 & 0.02 & 0.023 \\
\hline great-tailed grackle & 1 & 0.01 & 0.012 \\
\hline Bullock's oriole & 1 & 0.01 & 0.012 \\
\hline house finch & 16 & 0.19 & 0.056 \\
\hline house sparrow & 20 & 0.23 & 0.065 \\
\hline
\end{tabular}

a Seventy observations were on a single day. 
Table 5.2. Number of observations $(n)$ and frequency of detection of all birds seen or heard during eight-minute counts from VCP surveys, Casa Grande Ruins NM, 2001 and 2002. See Methods section for details on estimation of frequency of detection.

\begin{tabular}{|c|c|c|c|}
\hline \multirow[b]{2}{*}{ Species } & \multirow[b]{2}{*}{$n$} & \multicolumn{2}{|c|}{$\begin{array}{c}\text { Frequency of } \\
\text { detection }\end{array}$} \\
\hline & & Mean & SE \\
\hline Gambel's quail & 65 & 0.76 & 0.057 \\
\hline Swainson's hawk & 1 & 0.01 & 0.012 \\
\hline red-tailed hawk & 1 & 0.01 & 0.012 \\
\hline American kestrel & 11 & 0.13 & 0.049 \\
\hline prairie falcon & 2 & 0.02 & 0.016 \\
\hline sandhill crane & 12 & 0.14 & 0.140 \\
\hline killdeer & 1 & 0.01 & 0.012 \\
\hline black-necked stilt & 2 & 0.02 & 0.023 \\
\hline rock pigeon & 93 & 1.08 & 0.704 \\
\hline white-winged dove & 19 & 0.22 & 0.067 \\
\hline mourning dove & 155 & 1.80 & 0.136 \\
\hline Inca dove & 2 & 0.02 & 0.023 \\
\hline burrowing owl & 12 & 0.14 & 0.038 \\
\hline lesser nighthawk & 7 & 0.08 & 0.034 \\
\hline black-chinned hummingbird & 10 & 0.12 & 0.048 \\
\hline Anna's hummingbird & 16 & 0.19 & 0.045 \\
\hline Costa's hummingbird & 2 & 0.02 & 0.016 \\
\hline Gila woodpecker & 23 & 0.27 & 0.051 \\
\hline ladder-backed woodpecker & 1 & 0.01 & 0.012 \\
\hline gilded flicker & 20 & 0.23 & 0.071 \\
\hline western wood-pewee & 2 & 0.02 & 0.016 \\
\hline Say's phoebe & 1 & 0.01 & 0.012 \\
\hline ash-throated flycatcher & 18 & 0.21 & 0.044 \\
\hline western kingbird & 8 & 0.09 & 0.036 \\
\hline loggerhead shrike & 4 & 0.05 & 0.023 \\
\hline common raven & 5 & 0.06 & 0.025 \\
\hline horned lark & 14 & 0.16 & 0.074 \\
\hline cliff swallow & 185 & 2.15 & 0.988 \\
\hline verdin & 15 & 0.17 & 0.041 \\
\hline cactus wren & 16 & 0.19 & 0.042 \\
\hline northern mockingbird & 23 & 0.27 & 0.048 \\
\hline curve-billed thrasher & 1 & 0.01 & 0.012 \\
\hline European starling & 49 & 0.57 & 0.173 \\
\hline American pipit & 1 & 0.01 & 0.012 \\
\hline yellow warbler & 1 & 0.01 & 0.012 \\
\hline MacGillivray's warbler & 1 & 0.01 & 0.012 \\
\hline Wilson's warbler & 1 & 0.01 & 0.012 \\
\hline western tanager & 1 & 0.01 & 0.012 \\
\hline chipping sparrow & 2 & 0.02 & 0.023 \\
\hline Brewer's sparrow & 114 & 1.33 & 0.497 \\
\hline vesper sparrow & 1 & 0.01 & 0.012 \\
\hline lark sparrow & 2 & 0.02 & 0.023 \\
\hline lark bunting & 27 & 0.31 & 0.222 \\
\hline red-winged blackbird & 74 & 0.86 & 0.345 \\
\hline great-tailed grackle & 59 & 0.69 & 0.085 \\
\hline brown-headed cowbird & 4 & 0.05 & 0.028 \\
\hline Bullock's oriole & 1 & 0.01 & 0.012 \\
\hline house finch & 92 & 1.07 & 0.160 \\
\hline lesser goldfinch & 3 & 0.03 & 0.026 \\
\hline house sparrow & 68 & 0.79 & 0.128 \\
\hline
\end{tabular}

Table 5.3. Total number of observations $(n)$ and relative frequency of detection of birds recorded during linetransect surveys, Casa Grande Ruins NM, 2002. See Methods section for details on estimation of frequency of detection.

\begin{tabular}{|c|c|c|c|}
\hline \multirow[b]{2}{*}{ Common name } & \multirow[b]{2}{*}{$n$} & \multicolumn{2}{|c|}{ Frequency of detection } \\
\hline & & Mean & SE \\
\hline Gambel's quail & 1 & 0.02 & 0.021 \\
\hline great blue heron & 1 & 0.02 & 0.021 \\
\hline great egret & 1 & 0.02 & 0.021 \\
\hline northern harrier & 2 & 0.04 & 0.030 \\
\hline Cooper's hawk & 2 & 0.04 & 0.030 \\
\hline red-tailed hawk & 2 & 0.04 & 0.030 \\
\hline American kestrel & 1 & 0.02 & 0.021 \\
\hline merlin & 1 & 0.02 & 0.021 \\
\hline peregrine falcon & 1 & 0.02 & 0.021 \\
\hline killdeer & 1 & 0.02 & 0.021 \\
\hline rock pigeon & 28 & 0.60 & 0.574 \\
\hline mourning dove & 89 & 1.89 & 0.821 \\
\hline burrowing owl & 2 & 0.04 & 0.030 \\
\hline black-chinned hummingbird & 1 & 0.02 & 0.021 \\
\hline Anna's hummingbird & 19 & 0.40 & 0.099 \\
\hline Costa's hummingbird & 2 & 0.04 & 0.030 \\
\hline northern flicker & 1 & 0.02 & 0.021 \\
\hline gilded flicker & 10 & 0.21 & 0.080 \\
\hline Say's phoebe & 6 & 0.13 & 0.058 \\
\hline loggerhead shrike & 7 & 0.15 & 0.052 \\
\hline common raven & 2 & 0.04 & 0.043 \\
\hline verdin & 2 & 0.04 & 0.030 \\
\hline rock wren & 4 & 0.09 & 0.041 \\
\hline blue-gray gnatcatcher & 7 & 0.15 & 0.080 \\
\hline northern mockingbird & 1 & 0.02 & 0.021 \\
\hline European starling & 1 & 0.02 & 0.021 \\
\hline American pipit & 2 & 0.04 & 0.030 \\
\hline yellow-rumped warbler & 26 & 0.55 & 0.208 \\
\hline white-crowned sparrow & 46 & 0.98 & 0.300 \\
\hline great-tailed grackle & 75 & 1.60 & 0.891 \\
\hline house finch & 19 & 0.40 & 0.151 \\
\hline house sparrow & 4 & 0.09 & 0.051 \\
\hline
\end{tabular}


mourning dove, great-tailed grackle, and house finch (Appendix K). Conversely, 16 species were recorded at only one station. Of the most widespread species, the relative frequency of detections differed most among points for the house finch and least among points for the greattailed grackle.

There were (qualitatively) significant within-season changes in the bird community across four surveys periods (both years combined): 19 species were recorded in all four two-week periods, whereas 32 species were recorded in only one two-week period (the majority during April 15-31; Appendix L). These observations suggest that up to $40 \%$ of species recorded during VCP surveys were likely migrants, which underscores the importance of the monument to species that might only be present in the area for a brief period of time (for a review of the life history and conservation of neotropical migrants, see Rappole [1995]).

\section{Line-transect Surveys}

We observed 32 species during four surveys in the fall of 2002 (Table 5.3). The mourning dove and great-tailed grackle were the most frequently detected species (due to the low number of individuals detected on winter surveys we did not truncate detections by distance from point), and we recorded 19 species that were represented by only one or two individuals. We recorded eight species during line-transect surveys that we did not find during VCP surveys (Appendix C). The bird community was apparently dominated by a few abundant species during this time period (eight species comprised $85 \%$ of all detections) though this may be, to some extent, an artifact of the lower detectability of some species during the non-breeding season (Bibby et al. 2002) or at further distances from the observer.

\section{Nocturnal Surveys}

We recorded four species during nocturnal surveys: lesser nighthawk ( $n=11$ observations), great horned owl $(n=5)$, burrowing owl $(n=4)$, and barn owl $(n=2)$.

\section{Incidental and Breeding Observations}

We recorded 57 observations of 36 species outside of formal surveys, including eight observations for species that we did not find with any other survey type (Appendix C). We observed evidence of breeding activity for 11 species, most commonly mourning doves (Table 5.4). One notable observation for Gambel's quail in 2002 included active predation of a nest by a gopher snake

Table 5.4. Number of observations for each breeding behavior for birds, Casa Grande Ruins NM, 2001 and 2002. Breeding behaviors follow standards set by NAOAC (1990).

\begin{tabular}{|c|c|c|c|c|c|c|c|}
\hline \multirow[b]{2}{*}{ Common name } & \multicolumn{7}{|c|}{ Breeding behavior } \\
\hline & $\begin{array}{c}\text { Nest } \\
\text { building }\end{array}$ & $\begin{array}{c}\text { Nest with } \\
\text { eggs }\end{array}$ & $\begin{array}{l}\text { Nest with young } \\
\text { seen or heard }\end{array}$ & $\begin{array}{c}\text { Occupied } \\
\text { nest }\end{array}$ & $\begin{array}{c}\text { Adults carrying } \\
\text { food }\end{array}$ & $\begin{array}{c}\text { Distraction } \\
\text { displays }\end{array}$ & $\begin{array}{c}\text { Recently } \\
\text { fledged young }\end{array}$ \\
\hline Gambel's quail & & & & 1 & & & \\
\hline mourning dove & 1 & 2 & & 1 & & & \\
\hline Inca dove & 1 & & & & & & \\
\hline lesser nighthawk & & 1 & & & & & 1 \\
\hline common poorwill & & & & & & & 1 \\
\hline Anna's hummingbird & & & & & & 1 & \\
\hline gilded flicker & & & 1 & & & & 2 \\
\hline cliff swallow & & & & & & & 1 \\
\hline verdin & & & 1 & & 1 & & \\
\hline cactus wren & & & & 1 & & & \\
\hline European starling & & & 1 & & 1 & & \\
\hline
\end{tabular}




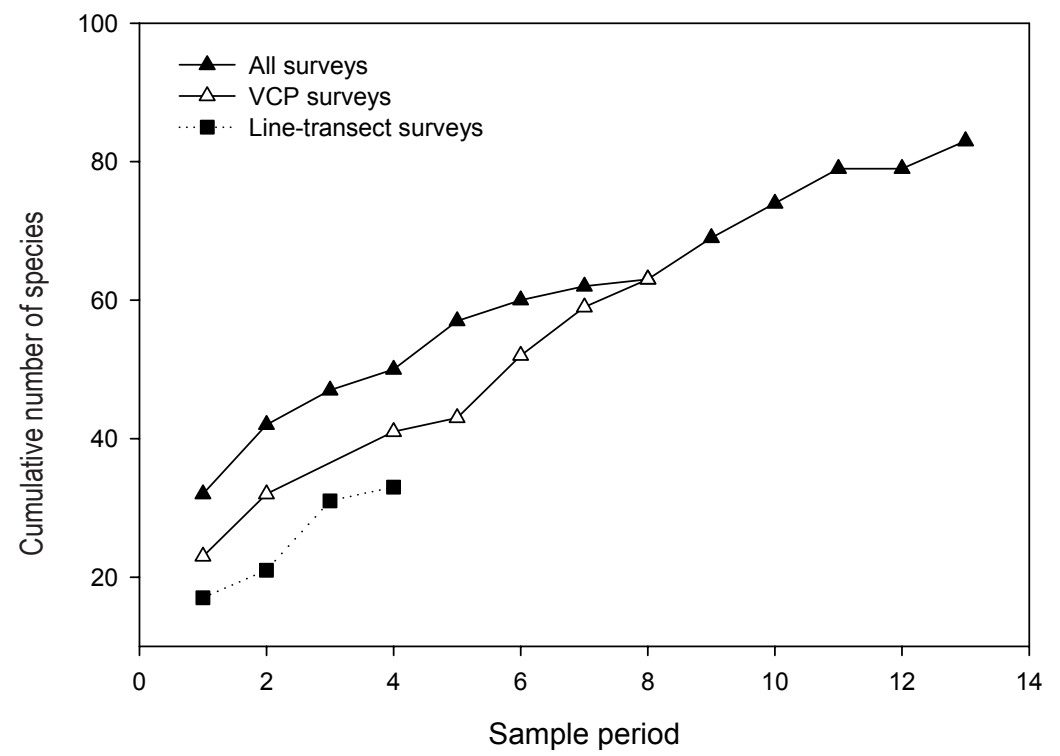

Figure 5.2. Species accumulation curves for detections from all bird surveys combined, Casa Grande Ruins NM, 2001 and 2002. Sample period for VCP and line-transect surveys represent one survey day and sample period for "all surveys" is a completely randomized combination of the four survey types, in which each period represents 100 observations. Sample curves for VCP and line transect surveys are randomized.

\section{Vegetation Characteristics}

Based on a qualitative assessment of our field data, vegetation was relatively uniform among stations. Creosote dominated the sparse shrub and subshrub layers and a few large mesquite trees provided overstory vegetation structure (Appendix M). The soil surface was predominately mineral soil.

\section{Inventory Completeness}

Based on our complete coverage of the monument for two breeding seasons, we believe that we recorded all of the species that permanently resided or bred in the monument. However, a species-accumulation curve (Fig. 5.2) suggests that we would record additional species with further effort. This is particularly true for migrant species. Because of their high mobility, it is not possible to determine exactly how many species of birds might occur at Casa Grande Ruins NM, but we believe that there are 62 species that are likely additions to the monument's species list (Appendix F).

\section{Discussion}

We recorded a surprising number of species of raptors; 10 species of diurnal raptors including all four species of falcons that are likely to occur in the area. Two of the 10 species, ferruginous hawk and peregrine falcon, are "Wildlife of Special Concern" in the state of Arizona (Appendix C). Although we did not investigate habitat use (i.e., identify or quantify resource use of birds), it is possible that these raptors were drawn to the abundant small mammal (i.e., roundtailed ground squirrel) and rabbit populations in the monument, particularly in contrast to the surrounding (primarily urban and agricultural) lands. Despite the high number of species that we detected, the number of detections for 
regionally rare or uncommon species (e.g., most falcons and migrating warblers) was low and may indicate that there might be just enough habitat to draw in a few individuals, but not enough to entice them to stay for long periods of time (i.e., it is a small "stopover" habitat). This would be particularly true for wide-ranging species such as raptors.

We recorded nine species of migrating warblers, most of which were represented by a few individuals (Appendix C). Casa Grande Ruins NM cannot support a large number of migratory birds because of its small size and lack of vegetation structure (see review in Skagen et al. 1998), but as development increases on the lands surrounding the monument, maintaining suitable habitat for species to use briefly during migration may become even more important.

\section{Abundance of Generalist Species}

All of the most abundant species at Casa Grande Ruins NM are considered human-adapted generalist species in southern Arizona. These species reach high densities in human-dominated landscapes; Mills et al. 1989, Germaine et al. 1998): mourning dove, rock pigeon, Gila woodpecker, cliff swallow, European starling, red-winged blackbird, great-tailed grackle, house finch, and house sparrow (Tables 5.1-5.3). Rock pigeon, house finch, and house sparrow regularly use the Casa Grande structure and therefore cause damage to the structure through roosting and nesting (Swann et al. 1994, NPS 1997). Although we observed the rock pigeon near the Casa Grande during incidental observations, we did not record them during VCP surveys at the station near the structure (Station 1, Fig. 5.1; Appendix K). They were probably roosting on the structure, but because the observer was stationary, the birds may not have been visible. The European starling is not considered a pest species at the monument, but we recorded them in high numbers around and on the Casa Grande structure (Brian Powell, pers. obs.).

Studies of bird communities in Tucson and Phoenix provide a useful comparison for evaluating the bird community at Casa Grande Ruins NM. Bird species richness in Phoenix was negatively correlated with a variety of urbanization-related factors that also affect Casa Grande Ruins NM area: bank stabilization, house and road density, and exotic plants (Green and Baker 2003). Most researchers studying urban/ suburban bird communities in the southwest stress the importance of maintaining (1) native vegetation in landscaping; and (2) a patchwork of native desert areas (Mills et al. 1989, Germaine et al. 1998). The latter does not exist in the immediate vicinity of the monument, and therefore we would expect the generalist species currently present at the monument to continue dominating the bird community and perhaps increase in abundance.

\section{Historical Changes in the Bird Community}

Because no quantitatively based studies had taken place prior to ours, it is difficult to place our findings in an historical context. Yet anecdotal information about the plant community at the monument is available, and plant communities are good predictors of bird species richness and presence (MacArthur and MacArthur 1961, Rice et al. 1984, Strong and Bock 1990). Before the drop in the groundwater table and subsequent loss of larger mesquite trees (see Chapter 2), Casa Grande Ruins NM hosted a number of bird species that are no longer found, most notably Crissal thrasher and northern cardinal (Fast 1936). Both of these species require a higher density of trees and shrubs than is currently present at the monument (Cody 1999, Powell and Steidl 2002). It is possible, given the monument's close proximity to the Gila River, that the area once had an extensive forest of large mesquites and a dense shrub layer, similar to what is currently found adjacent to some sections of the Santa Cruz and San Pedro rivers. Species that would nest in these vegetation types include Bell's vireo (Vireo bellii), Lucy's warbler (Vermivora luciae), yellow-breasted chat (Icteria virens), Abert's towhee (Pipilo aberti), and varied bunting (Passerina versicolor) (Powell et al. 2004). It is possible that habitat also existed for the cactus ferruginous pygmy owl [Glaucidium brasilianum (nanum)]. 


\section{Burrowing Owls}

We found burrowing owls during all survey types, in all seasons (Appendix C), and at VCP stations throughout the monument (Appendix $\mathrm{K})$. Burrowing owls are considered a Sensitive Species by the Bureau of Land Management (HDMS 2004) and in Arizona only small populations exist in areas dominated by agricultural, urban, and desert areas (Brown and Mannan 2002). Conway and Ellis (2004) completed an extensive survey of burrowing owls in the area in 2003; these researchers found 11 nest sites at the monument and 126 nests in the surrounding area. They also documented higher nest success at the monument (69\%) than in surrounding lands (55\%); additional research would be needed to determine if these differences are continuous over time. That study underscores a significant strength of singlespecies surveys: one could not have used data generated from our surveys to estimate density of owl burrows on the monument. 


\section{Chapter 6: Mammal Inventory}

\section{Previous and Ongoing Research}

Karen Monroe, a graduate student at the University of Arizona (School of Natural Resources), studied the movement patterns and life history of round-tailed ground squirrels (Koprowski and Monroe 2003). Swann et al. (1994) assessed the damage to cultural resources by birds and small mammals. We also located three mammal specimens collected from the monument (Appendix H).

\section{Methods}

We surveyed for mammals using three field methods: trapping for rodents and ground squirrels (primarily nocturnal; herein referred to collectively as small mammals), infraredtriggered photography for medium and large mammals, and incidental observations for all mammals. We did not net for bats because doing so without standing water would likely not have been productive (Ronnie Sidner, pers. comm.).

\section{Spatial Sampling Design}

We selectively placed 8 small-mammal trapping sites in areas of the monument that we felt represented slight variations in vegetation community and structure (Fig. 6.1). We avoided the vicinity of the picnic grounds because of the high density of round-tailed ground squirrels in that area and we prioritized the likelihood of documenting additional species in other areas. We subjectively placed infrared-triggered cameras in area of dense cover near animal trails.

\section{Small Mammals}

\section{Field Methods}

We trapped small mammals once in the spring and twice in the fall of 2002. We used Sherman ${ }^{\circledR}$ live traps (large, folding aluminum or steel, 3 x 3.5 x 9"; H. B. Sherman, Inc., Tallahassee,
FL) set in grids, with 12.5 -m or 15 -m spacing among traps arranged in configurations of five rows and five columns (eight plots) or 10 rows and five columns (one plot). On one plot (07) we placed five traps in a single row. We opened and baited (one tablespoon: 16 parts dried oatmeal to one part peanut butter) traps in the evening, then checked and closed traps the following morning. We placed a small amount of polyester batting in each trap to prevent trap deaths due to cold nighttime temperatures. We marked each captured animal with a permanent marker to facilitate recognition; these "batch marks" appeared to last for the duration of the sampling period. For each animal we recorded species, sex, age class (adult, subadult, or juvenile), reproductive condition, weight, and measurements for right-hind foot, tail, ear, and head, and body. For males we recorded reproductive condition as either scrotal or non-reproductive; for females we recorded reproductive condition as one or more of the following: non-reproducing, open pubis, closed pubis, enlarged nipples, small or non-present nipples, lactating, post-lactating, or non-lactating.

\section{Effort}

We trapped small mammals at eight sites (nine plots). The number of trap nights at each plot ranged from 1 to 3 and the number of traps set each night for each plot was 5 (plot 7), 25 (plots $1-6$, and 8 ), or 50 (plot 9). On one site (number 4) we trapped for only one night because ants were causing trap mortality. We placed two plots (1 and 8) at the same site on the first and last sampling period to quantify inter-seasonal changes in relative abundance.

\section{$\underline{\text { Analysis }}$}

We calculated relative abundance for species by dividing the number of captures by the number of trap nights (number of traps multiplied by number of nights they were open) after accounting for sprung traps (misfired or occupied; Beauvais and Buskirk 1999). Sprung traps reduce trap effort because they are no longer "available" to capture 

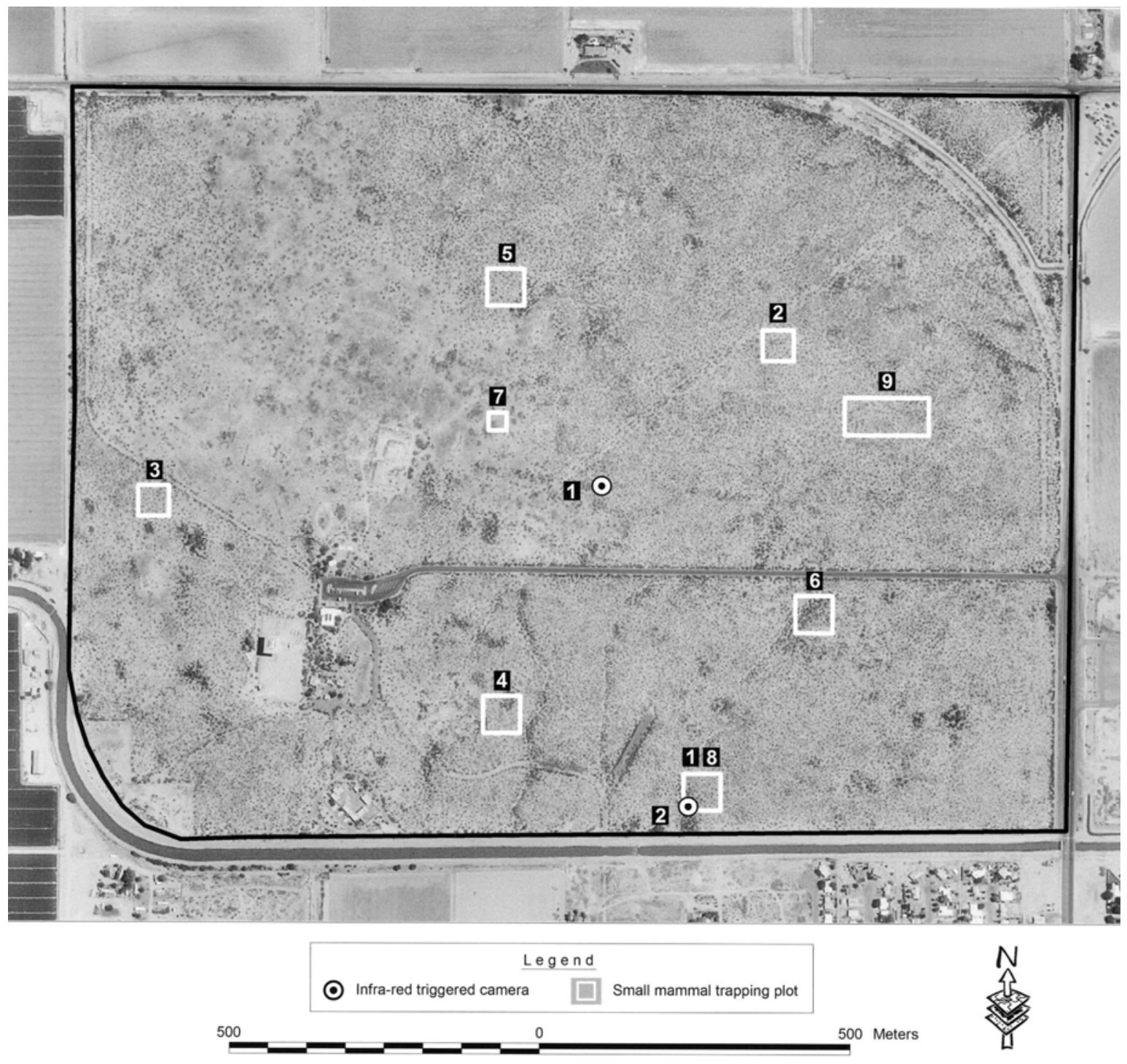

Figure 6.1. Location of small-mammal trapping plots and infrared-triggered cameras, Casa Grande Ruins NM, 2001 and 2002.

animals; we account for this by multiplying the number of sprung traps by 0.5 (lacking specific information, we estimate sprung traps were available for half of the night; Nelson and Clark 1973).

\section{Medium and Large Mammals}

\section{Field Methods}

We used infrared-triggered cameras (herein referred to as "Trailmaster"; Trailmaster ${ }^{\circledR}$; model 1500, Goodman and Associates, Inc, Lenexa, KS;
Kucera and Barrett 1993) to record the presence of medium and large mammals. Trailmasters have three components: receiver, transmitter, and camera (Fig. 6.2). The transmitter sends an infrared beam to the receiver at a specified rate ( 5 times per second for this study). The receiver then sends a signal (via cable) to a camera mounted on a tripod 6-8 m away. When an animal blocks the infrared beam, the camera takes a picture.

We set the receiver and transmitter approximately $8 \mathrm{~m}$ apart and $20 \mathrm{~cm}$ above the 


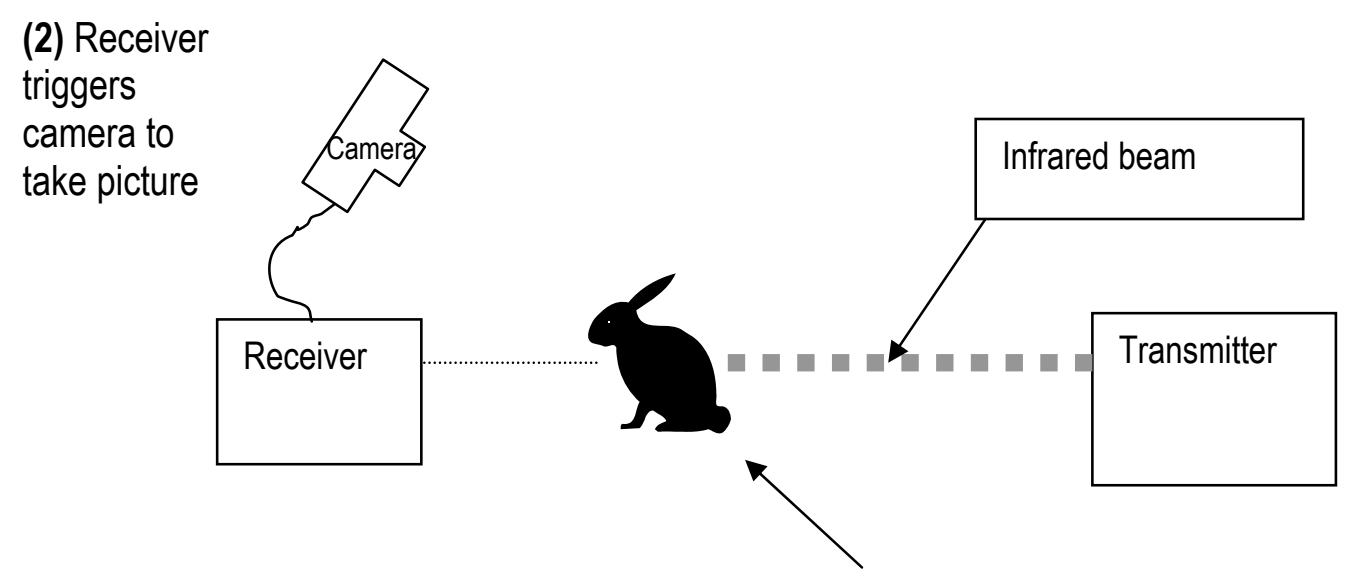

(1) Animal blocks infrared beam from getting to receiver

Figure 6.2. Diagram of Trailmaster camera set-up. Image based on Swann et al. (2004).

ground so that medium and large mammals were captured on film but smaller animals such as rodents and birds were not. We set cameras to take no more than one photograph every five minutes to reduce the chances of recording the same individual more than once on the same occasion. We placed cameras in two areas of the monument (Fig. 6.1) that we thought would record the highest number of species; typically these were in areas of dense vegetation. We baited camera sites with a commercial scent lure (ingredients included synthetic catnip oil, bobcat musk, beaver castorium, and propylene glycol as a preservative) or canned cat food. We checked cameras approximately every two weeks to change film and batteries and to ensure their proper function. We photographed a placard documenting the date and camera location on the first exposure of every new roll of film.

Effort

We operated Trailmaster cameras in the spring and summer of 2002 for a total of 134 days.

\section{Analysis}

Trailmaster cameras are the most cost-effective method for recording the presence of medium and large mammal species (Kucera and Barrett 1993, Cutler and Swann 1999). However, one drawback to this method is an inability to differentiate individuals, which precludes any estimates of abundance (i.e., one must be able to determine whether one animal has been photographed repeatedly or whether more than one individual has been photographed). In some cases, size or physical abnormality may differentiate individuals of any species, but this was not evident in our photographs. Also, each species is more or less likely to be attracted to the camera area. Therefore, we report the number of times a species was photographed to indicate species that may be common, based on the number of photographs.

\section{Incidental Observations and Sign}

As with other taxa, we recorded UTM coordinates of mammal sightings made outside of formal surveys. Observers from all field crews (e.g., bird crew) recorded mammal sightings. Because of the low number of observations by our crews, we also report observations by monument staff. Finally, we repeatedly checked the Casa Grande and roof structure for bats. 


\section{Results}

\section{Small Mammals}

Excluding recaptures, we trapped 154 individuals representing 7 species on a total of 470 trap nights (Table 6.1). The number of species trapped at sites ranged from 2 to 6 species (mean $=3.4 \pm 0.48$ ). After accounting for differences in trapping effort among sites, Merriam's kangaroo rat was the most widespread and abundant, though the Sonoran Desert pocket mouse was found on all but one grid and was almost as abundant. Combined relative abundance of the other five species was $18 \%$ of that for both Merriam's kangaroo rat and Sonoran Desert pocket mouse combined.

We placed two plots in the same location (plots 1 and 8; Fig. 6.1) for the first and last sampling periods (April and December, respectively), and we observed considerable differences in the structure of the small-mammal community between those sampling events. Species richness changed from 6 to 2 species, the number of individuals trapped increased from 11 to 19, and Merriam's kangaroo rat was the only species trapped in both sampling periods (Table 6.1).

\section{Medium and Large Mammals}

Trailmaster cameras took 30 photographs of animals. The most photographed species was the cottontail (Table 6.2). These animals were most likely desert cottontails; eastern cottontail (Sylvilagus floridanus) is difficult to differentiate in photographs, but is unlikely to be present in the area near the monument (Hoffmeister 1986).

Table 6.1. Total number of small mammals trapped ( $\mathrm{n}$ ) and percent relative abundance (PRA), excluding recaptures, Casa Grande Ruins NM, 2002.

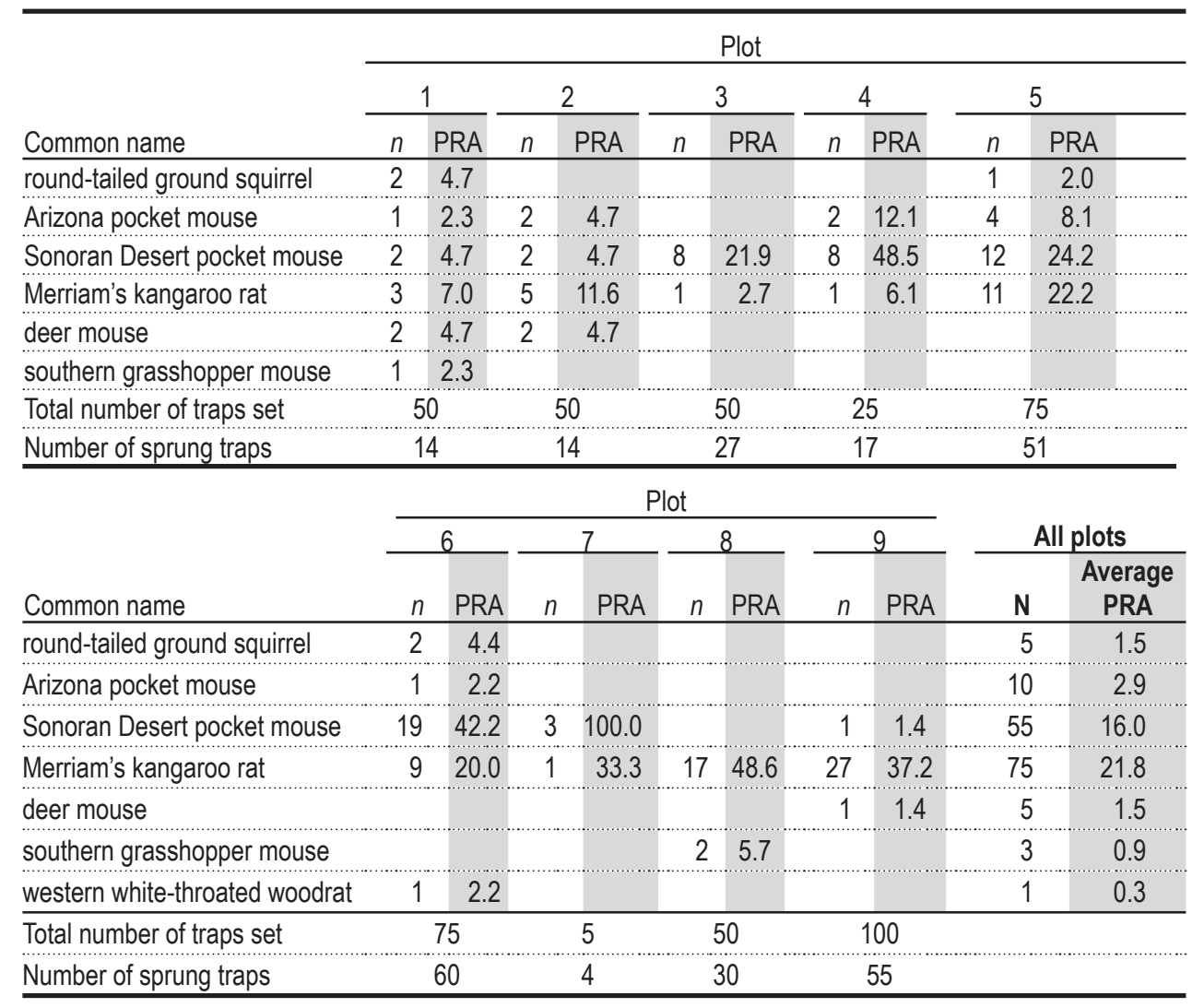


Table 6.2. Results of Trailmaster camera, incidental collection of sign, and incidental observations by University of Arizona inventory personnel and monument staff, Casa Grande Ruins NM.

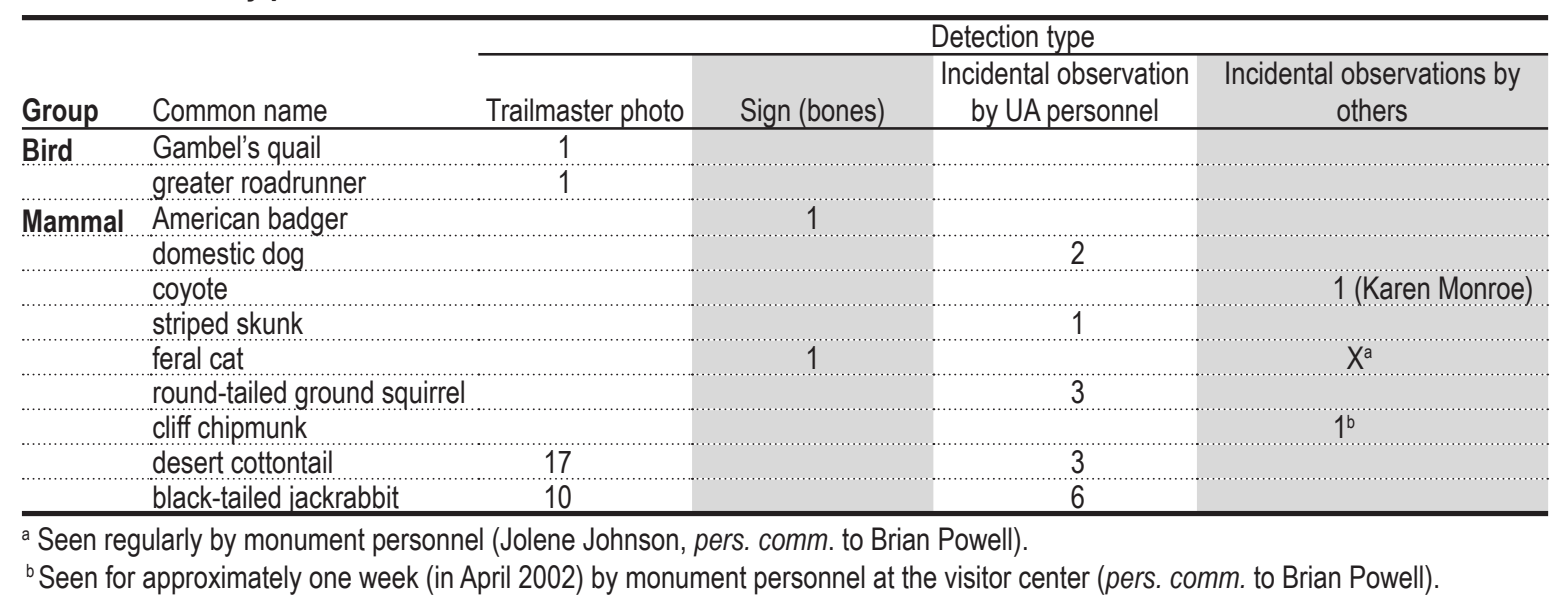

Cameras took 10 photographs of black-tailed jackrabbits and one photograph each of Gambel's quail, greater roadrunner, and western whitethroated woodrat.

\section{Incidental Observation and Sign}

University of Arizona personnel made incidental observations of 5 species during the course of the study (Table 6.2). Monument personnel reported regular observation of feral cats and a single observation of a cliff chipmunk. We did not observe bats in the Casa Grande or supporting roof structure.

\section{Specimen and Photograph Vouchers}

We took 17 specimen vouchers during the course of small-mammal trapping at the monument (Appendix I) and collected two skulls, one each of domestic cat and American badger (Table 6.2).

\section{Inventory Completeness}

\section{Small Mammals}

The majority of our mammal survey effort targeted small mammals. Based on a species accumulation curve, it appears that we trapped most of the species that occurred on the monument during the time of the study (Fig. 6.3). A number of species could be present or may historically have been present at the monument, based on range maps and published habitat associations, including: little pocket mouse, Bailey's pocket mouse, cactus mouse, Arizona cotton rat, and the non-native house mouse (Hoffmeister 1986; Appendix G). It is quite likely that these species, particularly cactus mouse and house mouse, would be captured with additional survey effort. Based on a site visit (but no trapping), Yar Petryszyn (in Swann et al. 1994) believed that the cactus mouse would be the main native rodent that would forage in the Casa Grande structure. Also, there are a few species that are within range but would require higher density of vegetation (particularly dense grasses and forbs): Botta's pocket gopher, silky pocket mouse, banner-tailed kangaroo rat, western harvest mouse, and hispid cotton rat (Hoffmeister 1986). Based on the description of the vegetation at the monument prior to cattle grazing and mesquite die-off (Clemensen 1992), it is likely that these species were once common residents of the monument. Also, Merriam's mouse, probably once common at the monument before the die-off of the large mesquite forest, is very restricted to that vegetation component and therefore unlikely to be present now. Finally, there is a group of species within range but preferring rockier substrates, as their names imply, (cliff chipmunk, rock squirrel, and rock pocket mouse), that may have used the monument during dispersal. The report of the cliff chipmunk (Table 6.2) should be considered a tentative identification. 


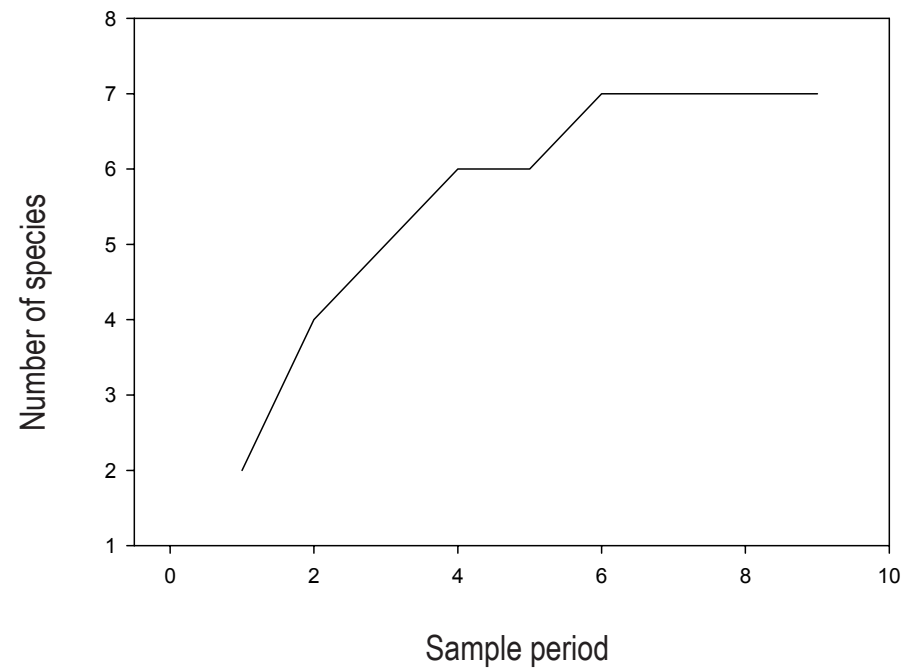

Figure 6.3. Species accumulation curve for small-mammal trapping at Casa Grande Ruins NM (2002). One sampling period represents one trapping event (1-3 days) per plot.

\section{Medium and Large Mammals}

Our Trailmaster survey effort was insufficient to document the medium and large mammals at the monument, despite having operated the cameras for 134 days. However, based on incidental observations by our survey crews and by monument staff, it appears that the species list of medium and large mammals that regularly use the monument is small: house cat, stripped skunk, domestic dog, and coyote (Table 6.2, Appendices $D, G)$. Because of close proximity to the Gila River and the natural areas to the north of the river, a host of other species may occasionally be present at the monument: raccoon, hooded and white-backed hog-nosed skunks, kit and gray fox, bobcat, collared peccary, and mule deer. Clemensen (1992) reports that fox, coyote, and bobcat have been seen at the monument.

\section{Bats}

We did not observe any bats during our inventory. Because of their high mobility, bats are much less dispersal-limited than most other mammals, and therefore could forage throughout the monument and the surrounding landscape. Therefore, we include a list of 18 species of bats that, based on range and habitat associations, could be present at Casa Grande Ruins NM (Appendix G). Of these, the Brazilian free-tailed bat is the only species that was once known to have bred at the monument (Clemensen 1992).

\section{Discussion}

Of all the groups that we studied, mammals are probably most affected by habitat fragmentation of the desert around the monument (Woodroffe and Ginsberg 1998). In general, the home range of mammals is proportionate to body size; larger animals require more land for life-history functions (Jetz et al. 2004). We found no large mammals (e.g., mountain lion, deer, or bear) during our surveys and no large mammals have been reported for decades (Clemensen 1992, Carol West, pers. comm. to Brian Powell). We observed or documented some medium-size mammals such as badger (skull), striped skunk (sighting), and feral cats and dogs (Table 6.2). Coyotes have been reported for the monument both historically (Clemensen 1992) and recently (Karen Monroe, pers. comm.).

Although no baseline exists for quantitatively evaluating changes in the mammal 
community at the monument, it is logical

to conclude that the surrounding land uses have negatively affected the native mammal community. The species richness and abundance of mammals have declined, and many of the permanent changes that we see today, such as no large mammals, may go back as early as the 1930s when the monument was surrounded by agricultural development (Clemensen 1992). One particularly striking change was the use of the Casa Grande by Brazilian ("Mexican") free-tailed bats. In 1944, monument personnel counted over 5,000 bats exiting the ruins, but by 1956 bats no longer lived on the monument (Clemensen 1992). This time period coincided with the increased use of insecticides, including DDT (see Chapter 2). More recently, Swann et al. (1994) did not find any bats or sign of bats on their inspection of the Casa Grande in the late summer and fall of 1993 nor did we find any bats during our surveys.
Although free-tailed bats have a large foraging range (Best and Geluso 2003), the combination of pesticide use and subsequent lack of insects in areas adjacent to the monument may prevent the bats from returning. However, changes in the bat population on the regional scale may also play a more important role in their return.

We were surprised to find a badger skull at the monument. Some features of the monument are probably ideal for badgers, such as alluvial soil for digging and an abundance of roundtailed ground squirrels, which are its main food source (Hoffmeister 1986). Badgers also provide nesting habitat for burrowing owls (Conway and Ellis 2004). With the increasing isolation of the monument from other undeveloped areas, it seems unlikely that badgers are now resident or will be in the future. It is unclear if the monument could sustain a badger population following a reintroduction effort. 


\section{Chapter 7: Management Implications}

Based on the data from this study and our knowledge of the natural resource issues at the monument, we suggest issues that affect management of the monument's natural resources. Coordination with other agencies, non-governmental organizations, and/or adjacent landowners may prove the best route to resolving some of these issues.

\section{Development Adjacent to the Monument}

The most serious threat to the biological diversity of Casa Grande Ruins NM is continued commercial and residential development of adjacent and nearby lands. Potential impacts of residential development include: an increase in number and extent of non-native plants (see Chapter 3); increased runoff of toxins and sediment, disruption of animal movement patterns, and habitat loss and fragmentation (Mills et al. 1989, Theobald et al. 1997, Riley et al. 2003); and increased harassment and mortality of native animals by feral and free-roaming pets (Coleman and Temple 1993). The monument is considering the acquisition of agricultural land to the west of the monument; ecological restoration of degraded desert lands underway elsewhere may prove instructive if the National Park Service chooses to bring native vegetation back to the area. Martin Karpiscak (University of Arizona Office of Arid Lands Studies) has done restoration work around the Palo Verde nuclear power plant near Phoenix. Also, Ann Phillips at the Tucson Audubon Society is an expert on desert restoration and is working to rehabilitate a site along the lower Santa Cruz River (north of Tucson).

\section{Managing Non-native and Pest Species}

There are many non-native plants and animals that pose significant threats to the monument's resources, both cultural and biological. It is beyond the scope of this project to review specific control techniques for each species. Many National Park Service units have consulted experts and developed a non-native species management plan to guide future management decisions. The work by Halvorson and Guertin (2003) would provide an excellent foundation for this process.

As mentioned in Chapter 1, our study was not designed to assess habitat use by vertebrate species, therefore our results do not provide species-specific data to the ongoing pest management issue at the monument (NPS 1997). However, based on our data, a number of striking community-level patterns emerge. First, the bird community is dominated by generalist species, including rock pigeon, house finch, and house sparrow (which are considered pest species). Given the increasing urbanization of the area surrounding the monument, we expect an increasing prevalence of generalist species, and therefore concur with the assertion in the monument's integrated pest management plan (IPM; NPS 1997) that any management action for pest birds in the monument will have to be part of a larger, long-term regional effort. Yet given the limited financial resources of the monument, this seems unrealistic. The most feasible solution may be an exclosure device or modification of the structure to eliminate habitat inside of the structure.

Round-tailed ground squirrels are considered the most important pest species at the monument because they are disturbing sensitive archaeological resources (Swann et al. 1994, NPS 1997). Unlike birds, it may be possible to significantly reduce the numbers of animals through trapping or poisoning. We agree with Swann et al. (1994) that modification of the existing habitat for round-tailed ground squirrels will likely have the most long lasting and desired effect. Swann et al. (1994) and the monument's IPM plan (NPS 1997) both note the presence of burrows made by larger mammals, which were assumed to be made in pursuit of ground squirrels. Based on our data, and on observations 
by monument staff, it appears that native mammals such as coyote, kit and gray fox, and bobcat are very rare. Given the loss of habitat for these species in the surrounding landscape we suggest that these species should not be trapped or shot, as indicated in the pest management plan (NPS 1997). 


\section{Chapter 8: Additional Inventories and Research}

In general, we feel that we have succeeded in balancing our efforts between qualitative surveys designed to detect the maximum number of species with quantitative, repeatable surveys designed to estimate relative abundance with an associated measure of precision. Additional inventories could reach the $90 \%$ completion mark for some taxonomic groups.

Monument managers are clearly interested in the effects that nearby land use and development have on the plants and vertebrates of the monument (NPS 2003a, 2003b). Given the small size of the monument, however, any study that investigates the monument's resources should be undertaken in the context of the larger landscape. For example, Conway and Ellis (2004) examined differences in reproductive success of burrowing owls between populations on the monument and those in nearby areas. This approach, which places the natural resources in the monument into a larger spatial context, puts NPS staff in a stronger position to maintain and enhance, or eliminate (e.g., non-native species) natural resources from the monument.

\section{Plants}

Additional general botanizing surveys, conducted during relatively wet years, should increase the species list for annual plants and possibly relocate species that were not recorded by our field crews but were found by others (Reichhardt 1992 and collections at the UA and WACC). We suggest that future surveys target sensitive areas such as along roadsides and on and around the mounds of sediment that are dredged from irrigation canals.

Specimens from the monument may be residing in the herbaria collections at Arizona State University and Northern Arizona University and an effort should be undertaken to query a recently created database that has this information. Caution should be taken, however, in accepting the list of species without confirming the proper identification of species or updating taxonomy (Halvorson 2003). Finally, use of modular plots throughout the monument would be an effective tool for monitoring long-term vegetation changes (see Powell et al. 2004).

\section{Amphibians and Reptiles}

An effective way to increase the species list for amphibians and reptiles is to take high-quality photographs of animals as they are seen. The collection of road-killed animals, particularly snakes, from along Highway 87 will likely add species to the inventory. Other inventory efforts in Sonoran Desert Network parks have benefited from collection of these indisputable forms of evidence by NPS staff (Don Swann, pers. comm.). A more in-depth study of roadkill adjacent to the monument (and nearby areas as well) would help quantify the effects of roads on herpetofauna and mammal communities.

\section{Birds}

Additional surveys during the winter season and during the spring and fall migrations will pick up species missed by efforts at other times. It is important to note, however, that bird lists are difficult to complete because birds are highly mobile. Only sites that are visited regularly by avid bird watchers (e.g., Madera Canyon, Ramsey Canyon, and Sonoita Creek Preserve in southern Arizona) have bird lists that can be considered to be "complete."

\section{Mammals}

The use of ultrasonic detectors to identify bat species is increasing, and many researchers are refining the field techniques and improving the technology (e.g., Johnson et al. 2002, Gannon et al. 2003). These technologies may become more useful in the coming years with such refinements.

Our Trailmaster camera effort was inadequate for documenting all medium and large mammals. Because infrared-triggered cameras 
are the best method for documenting medium and large mammals, we recommend establishing the camera in a number of locations and having monument staff check the cameras on a regular basis; camera operation and maintenance is a fairly simple and rewarding task for technically proficient staff members. Care must be taken in determining where to place camera units because of the potential for cameras to be damaged or stolen.

Round-tailed ground squirrels are considered a pest species by the monument (NPS 1997) because they are causing damage to the numerous structures at the monument. We did not attempt to quantify the population size or distribution of the species in the monument. If an attempt is made at reducing or eliminating round-tailed ground squirrels from the monument, we suggest a capture-recapture study (Nichols and Dickman 1996) to determine the population size before and after any action. This will help to determine if the action was successful at reaching target population levels. 


\section{Chapter 9: Literature Cited}

American Ornithologists' Union (AOU). 1998. Checklist of North American birds, seventh edition. American Ornithologists' Union and Allen Press Inc., Lawrence, KS.

American Ornithologists' Union (AOU). 2003. Fortysecond supplement to the American Ornithologists' Union checklist of North American birds. Auk 117:847-858.

Anderson, D. R. 2001. The need to get the basics right in wildlife field studies. Wildlife Society Bulletin 29:1294-1297.

Arizona Poison and Drug Information Center (APDIC). 2003. Accessed 20 February 2003 from APDIC website: http://www.pharmacy.arizona.edu/centers/ apdic/snakes.shtml.

Baker, R. J., L. C. Bradley, R. D. Bradley, J. W. Dragoo, M. D. Engstrom, R. S. Hoffmann, C. A. Jones, F. Reid, D. W. Rice, and C. Jones. 2003. Revised checklist of North American mammals north of Mexico, 2003. Occasional Papers of the Museum of Texas Tech University 229:1-23.

Barry, P. 1987. Bird checklist of Casa Grande Ruins National Monument and vicinity. Southwest Parks and Monument Association and United States Department of the Interior. List found on the Northern Prairie Wildlife Research Center home page: www.npwrc.usgs.gov/resource/othrdata/ chekbird/r2/casa.htm.

Beauvais, G. P. and S. W. Buskirk. 1999. Modifying estimates of sampling effort to account for sprung traps. Wildlife Society Bulletin 27:39-43.

Best, L. B. 1992. Characteristics of corn rootworm insecticide granules and the grit used by cornfield birds: evaluating potential avian risks. American Midland Naturalist 128:126-138.

Best, T. L., and K. N. Geluso. 2003. Summer foraging range of Mexican free-tailed bats (Tadarida brasiliensis mexicana) from Carlsbad Cavern, New Mexico. Southwestern Naturalist 48:590596.

Bibby, C. J., N. D. Burgess, and D. A. Hill. 2002. Bird census techniques. $2^{\text {nd }}$ Edition. Academic Press, London, England.

Bock, C. E., J. H. Bock, K. L. Jepson, and J.C. Ortega. 1986. Ecological effects of planting African lovegrasses in Arizona. National Geographic Research 2:456-463.
Bohlke, J. K. 2002. Groundwater recharge and agricultural contamination. Hydrogeology 10:153-179.

Boutin, C., K. E. Freemark, and D. A. Kirk. 1999. Farmland birds in southern Ontario: field use, activity patterns and vulnerability to pesticide use. Agriculture, Ecosystems and Environment 72:239-254.

Brooks, M. L., and D. A. Pyke. 2001. Invasive plants and fire in the deserts of North America. Tall Timbers Research Station Miscellaneous Publication 11:1-14.

Brown, N. L., and R. W. Mannan. 2002. Status of burrowing owl in Arizona. Grant report to Arizona Game and Fish Department, Phoenix, AZ.

Buckland, S. T., D. R. Anderson, K. P. Burnham, J. L. Laake, D. L. Borchers and L. Thomas. 2001. Introduction to distance sampling: Estimating abundance of biological populations. Oxford University Press, London, England.

Burt, W. H., and R. P. Grossenheider. 1976. The Peterson field guide series: a field guide to the mammals of North America north of Mexico. Houghton Mifflin, New York, NY.

Cain, A. T., V. R. Touvila, D. G. Hewitt, and M. E. Tewes. 2003. Effects of a highway and mitigation projects on bobcats in southern Texas. Biological Conservation 114:189-197.

Clark, B. K., B. S. Clark, L. A. Johnson, and M. T. Haynie. 2001. Influence of roads on movements of small mammals. Southwestern Naturalist 46:338-344.

Clarke A. L., and T. Pacin. 2002. Domestic cat "colonies" in natural areas: a growing exotic species threat. Natural Areas Journal 22:154-159.

Clemensen, A. B. 1992. A centennial history of the first prehistoric reserve: 1892-1992. United States Department of the Interior. National Park Service, Washington D.C.

Cody, M. L. 1999. Crissal thrasher. In Birds of North America: life histories for the $21^{\text {st }}$ century, No. 419. A. Poole and F. Gill, editors. The birds of North America, Inc., Philadelphia, PA.

Coleman, J. S., and S. A. Temple. 1993. Rural residents' free-ranging domestic cats: a survey. Wildlife Society Bulletin 21:381-390. 
Colver, K. J., D. Stokes, and L. Stokes. 1999. Stokes field guide to bird songs. Time Warner Trade, New York, NY.

Conway, C. J., and L. Ellis. 2004. Distribution, abundance, reproductive success, and survival of burrowing owls at Casa Grande Ruins National Monument and surrounding agricultural areas. Wildlife Research Report 05-2004. Arizona Cooperative Fish and Wildlife Research Unit, School of Natural Resources, University of Arizona, Tucson, AZ.

Corn, S. P. 1994. Straight-line drift fences and pitfall traps. Pp. 109-117. In W. R. Heyer, M. A. Donnelly, R. W. McDiarmid, L. C. Hayek, and M. S. Foster, editors. Measuring and monitoring biodiversity: standard methods for amphibians. Smithsonian Institution Press, Washington, D.C.

Crump, M. L., and N. J. Scott. 1994. Visual encounter surveys. Pp. 84-92. In W. R. Heyer, M. A. Donnelly, R. W. McDiarmid, L. C. Hayek, and M. S. Foster, editors. Measuring and monitoring biodiversity: standard methods for amphibians. Smithsonian Institution Press, Washington, D.C.

Currie, W. E. 1998. Historical pesticide use study for Casa Grande Ruins National Monument, Coolidge, Arizona. Unpublished report to the Grande Ruins National Monument.

Cutler, T. L., and D. E. Swann. 1999. Using remote photography in wildlife ecology: a review. Wildlife Society Bulletin 27:571-581.

D’Antonio, C. M., and P. M. Vitousek. 1992. Biological invasions by exotic grasses, the grass fire cycle, and global change. Annual Review of Ecology and Systematics 23:63-87.

Davis, K., and W. L. Halvorson. 2000. A study plan to inventory vascular plants and vertebrates: Sonoran Desert Network. Southern Arizona Office, National Park Service, Phoenix AZ.

Degenhardt, W. G., C. W. Painter, and A. H. Price. 1996. Amphibians and reptiles of New Mexico. University of New Mexico Press, Albuquerque, NM.

Ehrlich, P. R., D. S. Dobkin, and D. Wheye. 1988. The birder's handbook: a field guide to the natural history of North American birds. Simon and Schuster, New York, NY.

Fagerstone, K. A., H. P. Tietjen and G. K. LaVoie. 1977. Effects of range treatment with 2,4-D on prairie dog diet. Journal of Range Management 30:57-60.
Farnsworth, G. L., K. H. Pollack, J. D. Nichols, T. R. Simons, J. E. Hines, and J. R. Sauer. 2002. A removal model for estimating detection probabilities from point-count surveys. The Auk 119:414-425.

Fast, J. E. 1936. Bird Banding Notes. Southwestern Monuments. Supplement for February.

Fellers, G. M., and C. A. Drost. 1994. Sampling with artificial cover. Pp. 146-150. In W. R. Heyer, M. A. Donnelly, R. W. McDiarmid, L. C. Hayek, and M. S. Foster, editors. Measuring and monitoring biodiversity: Standard methods for amphibians. Smithsonian Institution Press, Washington, D.C.

Fletcher, J. S., T. G. Pfleeger and H. C. Ratsch. 1993. Potential environmental risks associated with the new Sulfonylurea herbicides. Environmental Science and Technology 27:2250-2252.

Freemark, K., and C. Boutin. 1995. Impacts of agricultural herbicide use on terrestrial wildlife in temperate landscapes: a review with special reference to North America. Agriculture, Ecosystems and Environment 52:67-91.

Fuller, M. R., and J. A. Mosher. 1987. Raptor survey techniques. Pp. 37-66. In B. A. GeronPendleton, B. A. Millsap, K. W. Cline, and D. M. Bird, editors. Raptor management techniques manual. National Wildlife Federation, Washington, D.C.

Gannon, W. L., R. E. Sherwin, and S. Haymond. 2003. On the importance of articulating assumptions when conducting acoustic studies of habitat use by bats. Wildlife Society Bulletin 31:45-61.

Germaine, S. S., S. S. Rosenstock, R. E. Schweinsburg, and W. S. Richardson. 1998. Relationships among breeding birds, habitat, and residential development in greater Tucson, Arizona. Ecological Applications 8:680-691.

Gibbons, J. M., and R. D. Semlitsch. 1981. Terrestrial drift fence with pitfall traps: an effective technique for quantitative sampling of animal populations. Brimleyana 7:1-6.

Green, D. M., and M. G. Baker. 2003. Urbanization impacts on habitat and bird communities in a Sonoran desert ecosystem. Landscape and Urban Planning 63:22-239.

Halvorson, W. L. 2003. Verification of plant specimens from Sonoran desert parks. Report to the Desert Southwest Cooperative Ecosystems Studies Unit, University of Arizona, Tucson, AZ. 
Halvorson, W. L., and P. Guertin. 2003. USGS Weeds in the West project: status of introduced plants in southern Arizona Parks. U.S. Geological Survey, Southwest Biological Science Center, Sonoran Desert Research Station, School of Natural Resources, University of Arizona, Tucson, AZ.

Hayek, L. C., and M. A. Buzas. 1997. Surveying natural populations. Columbia University Press, New York, NY.

Heritage Data Management System (HDMS). 2004. Arizona Game and Fish Department. Accessed 5 March from: http://www.gf.state.az.us/w_c/edits/ hdms_species_lists.html.

Hoffmeister, D. F. 1986. Mammals of Arizona. The University of Arizona Press, Tucson, AZ.

Hubbard, J. A., T. M. Mau-Crimmins, B. F. Powell, E. W. Albrecht, N. Chambers, and L. Carder. 2003. National Park Service Sonoran Desert Network monitoring plan: Phase II. Sonoran Desert Network, Tucson, AZ.

Ingram, M. 2000. Reptile and amphibian accounts. Pp. 41-50. In S. J. Phillips and P. W. Comus, editors. A natural history of the Sonoran Desert. ArizonaSonora Desert Museum Press, Tucson, AZ.

Integrated Taxonomic Information System (ITIS). 2005. Accessed on 20 March 2004. http://www. itis.usda.gov/index.html.

Ivanyi, C., J. Perry, T. R. Van Devender, and H. Lawler. 2000. Reptile and amphibian accounts. Pp. 533585. In S. J. Phillips and P. W. Comus, editors. A natural history of the Sonoran Desert. ArizonaSonora Desert Museum Press, Tucson, AZ.

Jetz, W., C. Carbone, J. Fulford, and J. H. Brown. 2004. The scaling of animal space use. Science 306:266-268.

Johnson, J. B., M. A. Menzel, J. W. Edwards, and W. M. Ford. 2002. A comparison of 2 acoustical bat survey techniques. Wildlife Society Bulletin 30:931-936.

Judd, B. I., J. M. Laughlin, H. R. Guenther and R. Handegarde. 1971. The lethal decline of mesquite on the Casa Grande Ruin National Monument. Great Basin Naturalist 31:152-159.

Koprowski, J. L., and K. Monroe. 2003. Ecology of round-tailed ground squirrels at Casa Grande Ruins National Monument. Proposal to Western National Parks Association.

Krebs, C. J. 1998. Ecological Methodology. Second Edition. Addison-Welsey Educational, Menlo Park, CA.
Kucera, T. E., and R. H. Barrett. 1993. The Trailmaster camera system for detecting wildlife. Wildlife Society Bulletin 21:505-508.

Latta, M. J., C. J. Beardmore, and T. E. Corman. 1999. Arizona Partners in Flight conservation plan. Technical Report 142. Nongame and Endangered Wildlife Program, Arizona Game and Fish Department, Phoenix, AZ.

MacArthur, R. H., and J. W. MacArthur. 1961. On bird species diversity. Ecology 42:594-598.

McNamee, G. 1994. Gila: the life and death of an American river. University of New Mexico Press, Albuquerque, NM.

Mills, G. S., J. B. Dunning Jr., and J. M. Bates. 1989. Effects of urbanization of breeding bird community structure in southwestern desert habitats. Condor 91:416-428.

Naeem, S., L. J. Thompson, T. H. Jones, J. H. Lawton, S. P. Lawler, and R. M. Woodfin. 1996. Changing community composition and elevated $\mathrm{CO}_{2}$. Pp. 93-100. In C. Korner, and F. A. Bazzaz, editors. Carbon dioxide, populations, and communities. Academic Press, San Diego, CA.

National Park Service (NPS). 1997. Integrated pest management plan. Casa Grande Ruins National Monument. U.S. Department of the Interior, Washington, D.C.

National Park Service (NPS). 1998. Resources Management Plan. Casa Grande Ruins National Monument. U.S. Department of the Interior, Washington, D.C.

National Park Service (NPS). 1992. NPS-75: Natural resources inventory and monitoring guidelines. U.S. Department of the Interior, Washington, D.C.

National Park Service (NPS). 2003a. Resource protection study environmental assessment/ assessment of effect. U.S. Department of the Interior, Coolidge, AZ.

National Park Service (NPS). 2003b. Casa Grande Ruins National Monument resource protection study. U.S. Department of the Interior, Coolidge, AZ.

National Park Service (NPS). 2004. NPS visitation database - park report. http://www2.nature.nps. gov/Npstats/npstats.cfm

Nelson, L., and F. W. Clark. 1973. Correction for sprung traps in catch/effort calculations of trapping results. Journal of Mammology 54:295-298. 
Nichols, J. D., and C. R. Dickman. 1996. Capturerecapture methods. Pp. 217-218 In Measuring and monitoring biological diversity: standard methods for mammals. D. E. Wilson, F. R. Cole, J. D. Nichols, R. Rudran, and M. S. Foster, editors. Smithsonian Institution Press, Washington D.C.

Nickens, P. 1996. Documentation of fieldwork and associated activities undertaken at Casa Grande Ruins National Monument, Arizona, March 2223, 1996. Unpublished report by Batelle-Pacific Northwest National Laboratory.

North American Ornithological Atlas Committee (NAOAC). 1990. Handbook for atlasing North American breeding birds. C. Smith, editor. Accessed 13 July 2001 from: http:// americanbirding.org/norac/atlascont.htm.

Office of Technology Assessment (OTA). 1993. Harmful non-indigenous species in the United States. OTA-F-565, U.S. Government Printing Office, Washington D.C.

Pimentel, D., and C. A. Edwards. 1982. Pesticides and ecosystems. BioScience 32:595-600.

Powell, B. F., and R. J. Steidl. 2000. Nesting habitat and reproductive success of southwestern riparian birds. Condor 102:823-831.

Powell, B. F. and R. J. Steidl. 2002. Habitat selection by riparian songbirds breeding in southern Arizona. Journal of Wildlife Management 66:1096-1103.

Powell, B. F., E. W. Albrecht, W. L. Halvorson, C. A. Schmidt, P. Anning, and K. Docherty. 2005. Vascular plant and vertebrate inventory of Tumacácori National Historical Park. USGS Open-File Report 2005-1142. U.S. Geological Survey, Southwest Biological Science Center, Sonoran Desert Research Station, University of Arizona, Tucson, AZ.

Powell, B. F., E. W. Albrecht, C. A. Schmidt, W. L. Halvorson, P. Anning, and K. Docherty. 2004. Vascular plant and vertebrate inventory of Casa Grande Ruins National Monument. Final report to the National Park Service, Sonoran Desert Inventory and Monitoring Program, Tucson, AZ .

Powell, B. F., E. W. Albrecht, W. L. Halvorson, and K. Docherty. 2003. Biological inventory report for the Sonoran Desert Network: 2002. Annual Report No. 2. Sonoran Desert Network Inventory Program. U.S. Geological Survey, Sonoran Desert Field Station and School of Natural Resources, University of Arizona, Tucson, AZ.
Powell, B. F., K. Docherty, and W. L. Halvorson. 2002. Biological inventory report for the Sonoran Desert Network: 2000 and 2001 field seasons. Annual Report No. 1. Sonoran Desert Network Inventory Program. U.S. Geological Survey, Sonoran Desert Field Station and School of Natural Resources, University of Arizona, Tucson, AZ.

Ralph, C. J., J. R. Sauer, S. Droege, technical editors. 1995. Monitoring bird populations by point counts. Gen. Tech. Rep. PSW-GTR-149. Pacific Southwest Research Station, Forest Service, U.S. Department of Agriculture, Albany, CA.

Rappole, J. H. 1995. The ecology of migrant birds: a neotropical perspective. Smithsonian Institution Press, Washington D.C.

Reichhardt, K. 1992. Natural vegetation of Casa Grande Ruins National Monument, Arizona. Cooperative National Park Resources Studies Unit. Technical Report NPS/WRUA/NRTR92/45.

Reynolds, R. T., J. M. Scott, and R. A. Nussbaum. 1980. A variable circular-plot method for estimating bird numbers. Condor 82:309-313.

Rice, J., B. W. Anderson, and R. D. Ohmart. 1984. Comparison of the importance of different habitat attributes to avian community organization. Journal of Wildlife Management 48:895-911.

Richardson Jr., J. J. 2002. Legal impediments to utilizing groundwater as a municipal water source in karst terrain in the United States. Environmental Geology 42:532-537.

Riley, S. P. D., R. M. Sauvajot, T. K. Fuller, E. C. York, D. A. Kamradt, C. Bromley, and R. K. Wayne. 2003. Effects of urbanization and habitat fragmentation on bobcats and coyotes in southern California. Conservation Biology 17:566-576.

Rosen, P. C. 2004. Expected present and historic herptofaunas of Casa Grande Ruins National Monument. Unpublished report to University of Arizona, School of Natural Resources, Inventory and Monitoring Program.

Rosen, P. C., and C. H. Lowe. 1994. Highway mortality of snakes in the Sonoran desert of southern Arizona. Biological Conservation 68:143-148.

Rosen, P. C., and K. Mauz. 2001. Biological values of the West Branch of the Santa Cruz river, with an outline for a potential reserve; including preliminary flora. Document for the Sonoran 
Desert Conservation Plan, Pima County Board of Supervisors, Tucson, AZ. http://www.co.pima. az.us/cmo/sdcp/sdcp2/reports/WB/WestBF.htm\#_ Toc524108384

Sauer, J. R., J. E. Hines, and J. Fallon. 2004. The North American Breeding Bird Survey, results and analysis 1966-2003. Version 2004.1. Patuxtant Wildlife Research Center, Laurel MD. http://www.mbr-pwrc.usgs.gov/bbs/bbs.html.

Seabloom, E. W., E. T. Borer, V. L. Boucher, R. S. Burton, K. L. Cottingham, L. Goldwasser, W. K. Gram, B. E. Kendall, F. Micheli. 2003. Competition, seed limitation, disturbance, and reestablishment of California native annual forbs. Ecological Applications 13:575-592.

Sibley, D. A. 2000. National Audubon Society: The Sibley guide to birds. Chanticleer Press, New York, NY.

Skagen, S. K., C. P. Melcher, W. H. Howe, and F. L. Knopf. 1998. Comparative use of riparian corridors and oases by migrating birds in southeast Arizona. Conservation Biology 12:896-909.

Sprouse, T., R. Emanuel, B. Tellman. 2002. Final report: surface water quality monitoring overview and assessment for the Sonoran Desert Network, National Park Service. Unpublished report. Water Resources Research Center, University of Arizona, Tucson, AZ.

Stebbins, R. C. 2003. A field guide to western reptiles and amphibians. Third edition. Houghton Mifflin, New York, NY.

Stohlgren, T. J., J. F. Quinn, M. Ruggiero, and G. S. Waggoner. 1995. Status of biotic inventories in U.S. national parks. Biological Conservation 71:97-106.

Strong, T. R., and C. E. Bock. 1990. Bird species distribution patterns in riparian habitats in southeastern Arizona. Condor 92:511-519.

Swann, D. E., C. C. Hass, D. C. Dalton, and S. A. Wolf. 2004. Infrared-triggered cameras for detecting wildlife: an evaluation and review. Wildlife Society Bulletin 32:1-9.

Swann, D. E., W. W. Shaw, and C. R. Schwalbe. 1994. Assessment of animal damages to archeological resources at Casa Grande Ruins National Monument. Final report to Southern Arizona Group. National Park Service. Phoenix, AZ.

Tigas, L. A., D. H. Van Vuren, and R. M. Sauvajot. 2002. Behavioral responses of bobcats and coyotes to habitat fragmentation and corridors in an urban environment. Biological Conservation 108:299-306.

Tietjen, H. P., C. H. Halvorson, P. L. Hegdal and A. M. Johnson. 1967. 2,4-D herbicide, vegetation, and pocket gopher relationships Black Mesa, Colorado. Ecology 48:634-643.

Theobald, D. M., J. R. Miller, and N. T. Hobbs. 1997. Estimating the cumulative effects of development on wildlife habitat. Landscape and Urban Planning 39:25-36.

Trombulak, S. C., and C. A. Frissell. 2000. Review of ecological effects of roads on terrestrial and aquatic communities. Conservation Biology 14:18-30.

United States Department of Agriculture (USDA). 2005. The PLANTS Database, Version 3.5 (http://plants.usda.gov). National Plant Data Center, Natural Resources Conservation Service, Baton Rouge, LA.

Van Pelt, D. 1998. Assessing impacts of dropping water table in Casa Grande Ruins National Monument. M.S. Thesis, Department of Hydrology and Water Resources, University of Arizona, Tucson, AZ.

Verner, J., and L. V. Ritter. 1983. A comparison of transects and point counts in oak-pine woodlands of California. Condor 87:47-68.

Western Regional Climate Center (WRCC). 2004. Arizona climate summaries for Casa Grande Ruins National Monument. http://www.wrec.dri. edu/summary/climsmaz.html

Woodroffe, R., and J. R. Ginsberg. 1998. Edge effects and extinction of populations inside protected areas. Science 280:2126-2128. 
Appendix A. List of plant species observed or documented at Casa Grande Ruins NM by University of Arizona Inventory personnel (I\&M), 2001 and 2002 or other studies or collections. Halvorson and Guertin (2003; H\&G), Reichhardt (1992; Reichht), specimens at the University of Arizona (UA) or the Western Archaeological Conservation Center (WACC). Species in bold-faced type are non-native according to USDA (2004).

\begin{tabular}{|c|c|c|c|c|c|c|c|}
\hline Family & Scientific name & Common name & I\&M & $H \& G$ & Reichht $^{\mathrm{a}}$ & $U A^{b}$ & WACC \\
\hline Apiaceae & Bowlesia incana Ruiz \& Pavón & hoary bowlesia & $x$ & & $x$ & & \\
\hline Apocynaceae & Nerium oleander $L$. & oleander & & & $\mathrm{X}$ & & \\
\hline Asclepiadaceae & $\begin{array}{l}\text { Funastrum cynanchoides (Dcne.) Schlechter ssp. } \\
\text { heterophyllum (Vail) Kartesz, comb. nov. ined. }\end{array}$ & Hartweg's twinevine & $X$ & & & & \\
\hline \multirow[t]{30}{*}{ Asteraceae } & Acourtia nana (Gray) Reveal \& King & dwarf desertpeony & $\mathrm{X}$ & & \multirow{4}{*}{$\begin{array}{l}X \\
X\end{array}$} & & \\
\hline & Ambrosia psilostachya DC. & Cuman ragweed & \multirow{3}{*}{$\mathrm{X}$} & & & & \\
\hline & Antheropeas lanosum (Gray) Rydb. & white easterbonnets & & & & $\mathrm{X}$ & \\
\hline & $\begin{array}{l}\text { Aphanostephus ramosissimus DC. var. humilis } \\
\text { (Benth.) B.L. Turner \& Birdsong }\end{array}$ & plains dozedaisy & & & & $\mathrm{X}$ & \\
\hline & Baccharis sarothroides Gray & desertbroom & \multirow[t]{6}{*}{$X$} & & \multirow[b]{2}{*}{$\mathrm{X}$} & & \multirow{4}{*}{$X$} \\
\hline & Baileya multiradiata Harvey \& Gray ex Gray & desert marigold & & & & & \\
\hline & Centaurea melitensis L. & Maltese star-thistle & & $\mathrm{X}$ & $\mathrm{X}$ & & \\
\hline & Conyza canadensis (L.) Crong. & Canadian horseweed & & $\mathrm{X}$ & \multirow{4}{*}{$\underline{x}$} & & \\
\hline & Dimorphotheca sinuata DC. & glandular cape marigold & & $\mathbf{X}$ & & & \multirow{3}{*}{$\mathrm{X}$} \\
\hline & Erigeron divergens Torr. \& Gray & spreading fleabane & & & & & \\
\hline & Evax verna Raf. var. verna Raf. & spring pygmycudweed & $X$ & & & & \\
\hline & Filago arizonica Gray & Arizona cottonrose & \multirow[t]{3}{*}{$X$} & & \multirow{3}{*}{$\underline{X}$} & & \multirow[b]{2}{*}{$X$} \\
\hline & Helianthus annuus L. & common sunflower & & & & $\mathrm{X}$ & \\
\hline & Heterotheca subaxillaris (Lam.) Britt. \& Rusby & camphorweed & & & & $x$ & $\mathrm{X}$ \\
\hline & Isocoma acradenia (Greene) Greene & alkali goldenbush & \multirow{7}{*}{$\begin{array}{l}X \\
X\end{array}$} & & \multirow[b]{2}{*}{$X$} & $\mathrm{X}$ & \multirow{3}{*}{$X$} \\
\hline & Isocoma pluriflora (Torr. \& Gray) Greene & southern goldenbush & & & & & \\
\hline & Lactuca serriola L. & prickly lettuce & & $\mathbf{X}$ & \multirow[b]{2}{*}{$\underline{X}$} & & \\
\hline & Laennecia coulteri (Gray) Nesom & conyza & & & & $\mathrm{X}$ & \multirow[b]{2}{*}{ X } \\
\hline & Laennecia schiedeana (Less.) Nesom & pineland marshtail & & & \multirow{3}{*}{$\underline{X}$} & & \\
\hline & Lasthenia californica DC. ex Lindl. & California goldfields & & & & & $\mathrm{X}$ \\
\hline & Machaeranthera arida B.L. Turner \& Horne & arid tansyaster & & & & $\mathrm{X}$ & $\mathrm{X}$ \\
\hline & Matricaria discoidea DC & disc mayweed & & & \multirow[b]{2}{*}{$\underline{X}$} & $\mathrm{X}$ & $\mathrm{x}$ \\
\hline & Pectis papposa Harvey \& Gray & manybristle cinchweed & $X$ & & & $\mathrm{X}$ & $\mathrm{X}$ \\
\hline & Sonchus asper (L.) Hill & spiny sowthistle & \multirow[t]{3}{*}{$X$} & & & $\mathbf{X}$ & \\
\hline & Sonchus oleraceus L. & common sowthistle & & & $\mathbf{X}$ & $\mathrm{x}$ & $\mathbf{X}$ \\
\hline & Stephanomeria pauciflora (Torr.) A. Nels. & brownplume wirelettuce & & & $X$ & & $\mathrm{X}$ \\
\hline & Verbesina encelioides (Cav.) Benth. \& Hook. f. ex & & $X$ & & & $\mathrm{X}$ & $\mathrm{X}$ \\
\hline & $\begin{array}{l}\text { Gray } \\
\text { Verbesina encelioides (Cav.) Benth. \& Hook. f. ex }\end{array}$ & golden crownbeard & & & & & \\
\hline & Gray ssp. exauriculata (Robins. \& Greenm.) J.R. & & & & $\underline{X}$ & & \\
\hline & Coleman & golden crownbeard & & & & & \\
\hline Boraginaceae & $\begin{array}{l}\text { Amsinckia menziesii (Lehm.) A. Nels. \& J.F. Macbr. } \\
\text { var. intermedia (Fisch \& C.A. Mey.) Ganders }\end{array}$ & common fiddleneck & $X$ & & $\mathrm{X}$ & $\mathrm{X}$ & \\
\hline & Amsinckia tessellata Gray & bristly fiddleneck & & & $X$ & $\mathrm{X}$ & $\mathrm{X}$ \\
\hline & Cryptantha angustifolia (Torr.) Greene & Panamint cryptantha & $X$ & & $\underline{X}$ & & $\mathrm{X}$ \\
\hline & $\begin{array}{l}\text { Lappula occidentalis (S. Wats.) Greene var. } \\
\text { occidentalis (S. Wats.) Greene }\end{array}$ & flatspine stickseed & $X$ & & & $\mathrm{X}$ & \\
\hline & $\begin{array}{l}\text { Pectocarya heterocarpa (I.M. Johnston) I.M. } \\
\text { Johnston }\end{array}$ & chuckwalla combseed & $X$ & & $X$ & $\mathrm{X}$ & \\
\hline & Pectocarya penicillata (Hook. \& Arn.) A. DC & sleeping combseed & & & $\underline{X}$ & & \\
\hline & $\begin{array}{l}\text { Pectocarya platycarpa (Munz \& Johnston) Munz \& } \\
\text { Johnston }\end{array}$ & broadfruit combseed & & & $X$ & & \\
\hline & Plagiobothrys arizonicus (Gray) Greene ex Gray & Arizona popcornflower & $\mathrm{X}$ & & $\mathrm{X}$ & $\mathrm{X}$ & \\
\hline Brassicaceae & Brassica tournefortii Gouan & Asian mustard & $\mathbf{X}$ & $\mathbf{X}$ & $\underline{\mathbf{x}}$ & & $\mathbf{x}$ \\
\hline & Descurainia pinnata (Walt.) Britt. & western tansymustard & $\mathrm{X}$ & & & $\mathrm{X}$ & $X$ \\
\hline & $\begin{array}{l}\text { Descurainia pinnata (Walt.) Britt. ssp. pinnata } \\
\text { (Walt.) Britt. }\end{array}$ & western tansymustard & & & $\underline{X}$ & & \\
\hline & Descurainia sophia (L.) Webb ex Prantl & herb sophia & & $\mathbf{X}$ & & & \\
\hline & Lepidium lasiocarpum Nutt. & shaggyfruit pepperweed & $\mathrm{X}$ & & $\mathrm{X}$ & $\mathrm{X}$ & $\mathrm{X}$ \\
\hline & Lesquerella tenella A. Nels. & Moapa bladderpod & & & & $\mathrm{X}$ & \\
\hline & Sisymbrium irio L. & London rocket & $\mathbf{x}$ & $\mathbf{X}$ & $\mathrm{x}$ & $\mathrm{X}$ & $\mathbf{X}$ \\
\hline Cactaceae & Carnegia gigantea (Engelm.) Britt. \& Rose & saguaro & $X$ & & $\mathrm{X}$ & & \\
\hline
\end{tabular}




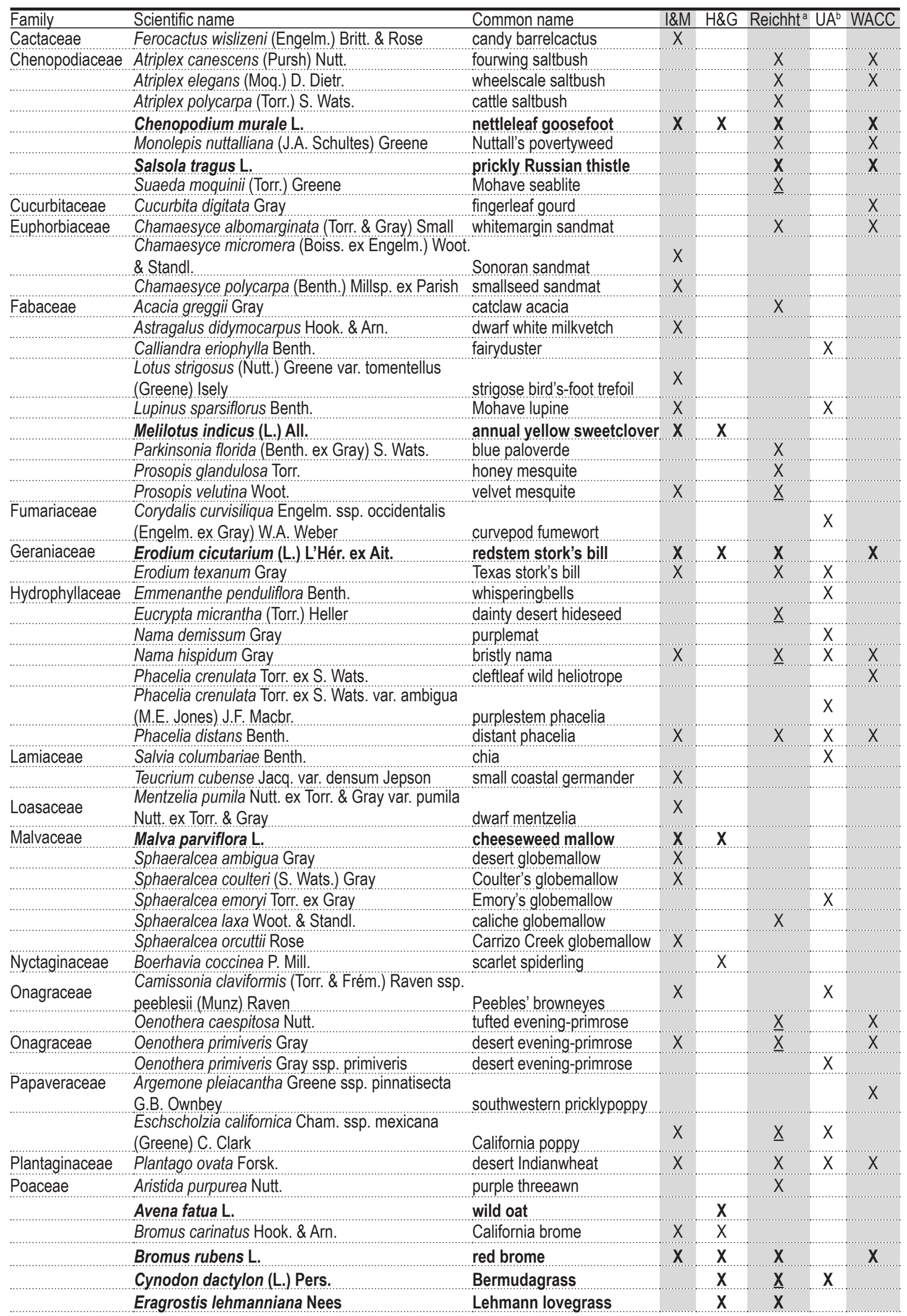




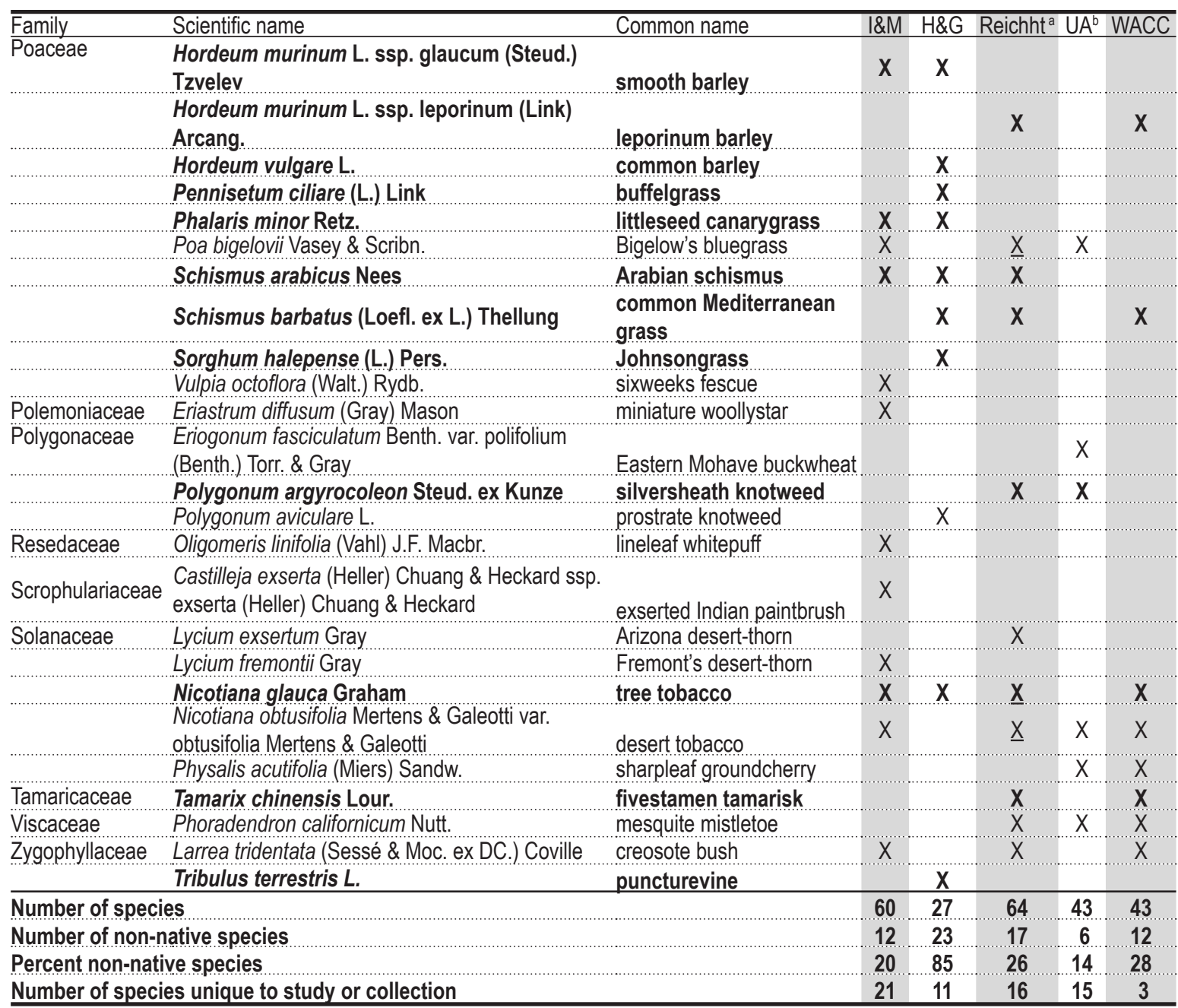

a Underlined species were reported in Reichhardt (1992) but collected by another individual. Some of these specimens are in the herbarium at the Arizona State University or at WACC.

${ }^{\mathrm{b}}$ All specimens were collected from 1939-1942 except Phacelia distans, which was collected in 1916.

Appendix B. Amphibian and reptile species documented with photograph (P) or specimen (S) voucher by University of Arizona Inventory personnel, Casa Grande Ruins NM, 2001 and 2002. See Appendix I for additional information on specimen and photograph vouchers.

\begin{tabular}{|c|c|c|c|c|}
\hline Order & Family & Scientific name & Common name & Type of documentation \\
\hline \multirow[t]{3}{*}{ Anura } & Pelobatidae & Scaphiopus couchii & Couch's spadefoot & $\mathrm{S}$ \\
\hline & Bufonidae & Bufo alvarius & Sonoran desert toad & $P$ \\
\hline & & Bufo cognatus & Great Plains toad & $P$ \\
\hline \multirow[t]{11}{*}{ Squamata } & Eublepharidae & Coleonyx variegatus & western banded gecko & $P$ \\
\hline & Phrynosomatidae & Sceloporus magister ${ }^{\mathrm{a}}$ & desert spiny lizard & $P$ \\
\hline & & Uta stansburiana ${ }^{a}$ & common side-blotched lizard & $P$ \\
\hline & & Urosaurus graciosus ${ }^{a}$ & long-tailed brush lizard & $P$ \\
\hline & Teiidae & Cnemidophorus tigris ${ }^{\mathrm{a}}$ & western (tiger) whiptail & $P$ \\
\hline & Colubridae & Masticophis flagelluma & coachwhip & $P$ \\
\hline & & Pituophis catenifer & gopher snake & $P$ \\
\hline & & Lampropeltis getula & common kingsnake & $P$ \\
\hline & & Rhinocheilus lecontei ${ }^{a}$ & long-nosed snake & $P$ \\
\hline & Viperidae & Crotalus atrox & western diamond-backed rattlesnake & $P$ \\
\hline & & Crotalus scutulatus ${ }^{\mathrm{a}}$ & Mojave rattlesnake & $\mathrm{P}$ \\
\hline
\end{tabular}

${ }^{a}$ Also found by Charles Conner (pers. comm.). 
Appendix C. Number of observations of birds by University of Arizona Inventory personnel, by survey type, Casa Grande Ruins NM, 2001 and 2002. Numbers of individuals recorded are not scaled by search effort and should not to be used for comparison among species. Underlined species are neotropical migrants (Rappole 1995). Species in bold-faced type are non-native.

\begin{tabular}{|c|c|c|c|c|c|c|c|}
\hline \multirow[b]{2}{*}{ Order } & \multirow[b]{2}{*}{ Family } & \multirow[b]{2}{*}{ Scientific name } & \multirow[b]{2}{*}{ Common name } & \multicolumn{4}{|c|}{ Number of individuals by survey type } \\
\hline & & & & VCP & $\begin{array}{l}\text { Line } \\
\text { transect }\end{array}$ & & Incidental \\
\hline Anseriformes & Anatidae & Anas platyrhynchos & mallard & 4 & & & \\
\hline \multirow{4}{*}{ Galliformes } & Odontophoridae & Callipepla gambelii & Gambel's quail & 140 & 1 & & 1 \\
\hline & Ardeidae & Ardea herodias & great blue heron & & 1 & & \\
\hline & & Ardea alba & great egret ${ }^{a}$ & & 1 & & 1 \\
\hline & Cathartidae & Cathartes aura & turkey vulture & & & & 1 \\
\hline \multirow[t]{10}{*}{ Falconiformes } & Accipitridae & Circus cyaneus & northern harrier & 1 & 2 & & 1 \\
\hline & & Accipiter cooperii & Cooper's hawk & & 2 & & 1 \\
\hline & & Parabuteo unicinctus & Harris's hawk & & & & 1 \\
\hline & & Buteo swainsoni & Swainson's hawk & 1 & & & \\
\hline & & Buteo jamaicensis & red-tailed hawk & 1 & 2 & & 2 \\
\hline & & Buteo regalis & ferruginous hawk a,b & & & & 1 \\
\hline & Falconidae & Falco sparverius & American kestrel & 15 & 1 & & 1 \\
\hline & & Falco columbarius & merlin & & 1 & & \\
\hline & & Falco peregrinus & peregrine falcon $\mathrm{a}, \mathrm{b}, \mathrm{c}$ & & 1 & & \\
\hline & & Falco mexicanus & prairie falcon & 2 & & & \\
\hline Gruiformes & Gruidae & Grus canadensis & sandhill crane & 12 & & & \\
\hline \multirow[t]{2}{*}{ Charadriiformes } & Charadriidae & Charadrius vociferus & killdeer & 1 & 1 & & \\
\hline & Recurvirostridae & Himantopus mexicanus & black-necked stilt & 2 & & & \\
\hline \multirow[t]{4}{*}{ Columbiformes } & Columbidae & Columba livia & rock pigeon & 113 & 28 & & \\
\hline & & Zenaida asiatica & white-winged dove & 33 & & & \\
\hline & & Zenaida macroura & mourning dove & 507 & 89 & & 6 \\
\hline & & Columbina inca & Inca dove & 2 & & & 3 \\
\hline Cuculiformes & Cuculidae & Geococcyx californianus & greater roadrunner & 1 & & & \\
\hline \multirow[t]{3}{*}{ Strigiformes } & Tytonidae & Tyto alba & barn owl & & & 2 & 1 \\
\hline & Strigidae & Bubo virginianus & great horned owl & & & 5 & \\
\hline & & $\frac{\text { Athene cunicularia }}{\text { hypugaea }}$ & burrowing owl ${ }^{b, d}$ & 17 & 2 & 4 & 6 \\
\hline \multirow[t]{2}{*}{ Caprimulgiformes } & Caprimulgidae & Chordeiles acutipennis & lesser nighthawk & 13 & & 16 & 8 \\
\hline & & Phalaenoptilus nuttallii & common poorwill & & & & 3 \\
\hline \multirow[t]{3}{*}{ Apodiformes } & Trochilidae & Archilochus alexandri & black-chinned hummingbird & 14 & 1 & & 2 \\
\hline & & Calypte anna & Anna's hummingbird & 20 & 19 & & \\
\hline & & Calypte costae & Costa's hummingbird & 2 & 2 & & \\
\hline \multirow[t]{4}{*}{ Piciformes } & Picidae & Melanerpes uropygialis & Gila woodpecker ${ }^{c}$ & 23 & & & \\
\hline & & Picoides scalaris & ladder-backed woodpecker & 1 & & & \\
\hline & & Colaptes auratus & northern flicker & & 1 & & \\
\hline & & Colaptes chrysoides & gilded flicker ${ }^{c}$ & 29 & 10 & & 3 \\
\hline \multirow[t]{16}{*}{ Passeriformes } & Tyrannidae & Contopus sordidulus & western wood-pewee & 3 & & & 1 \\
\hline & & Empidonax wrightii & gray flycatcher & 1 & & & \\
\hline & & Sayornis saya & Say's phoebe & 1 & 6 & & \\
\hline & & Myiarchus cinerascens & ash-throated flycatcher & 19 & & & 2 \\
\hline & & Tyrannus verticalis & western kingbird & 11 & & & \\
\hline & Laniidae & Lanius ludovicianus & loggerhead shrike ${ }^{\mathrm{b}}$ & 4 & 7 & & 1 \\
\hline & Corvidae & Corvus corax & common raven & 6 & 2 & & \\
\hline & Alaudidae & Eremophila alpestris & horned lark & 24 & & & \\
\hline & Hirundinidae & Petrochelidon pyrrhonota & cliff swallow & 335 & & & \\
\hline & Remizidae & Auriparus flaviceps & verdin & 15 & 2 & & 2 \\
\hline & Troglodytidae & Salpinctes obsoletus & rock wren & & 4 & & \\
\hline & & $\begin{array}{l}\text { Campylorhynchus } \\
\text { brunneicapillus }\end{array}$ & cactus wren & 19 & & & 3 \\
\hline & Sylviidae & Polioptila caerulea & blue-gray gnatcatcher & & 7 & & 1 \\
\hline & & Polioptila melanura & black-tailed gnatcatcher & 1 & & & 1 \\
\hline & Mimidae & Mimus polyglottos & northern mockingbird & 25 & 1 & & \\
\hline & & Toxostoma curvirostre & curve-billed thrasher & 1 & & & \\
\hline
\end{tabular}




\begin{tabular}{|c|c|c|c|c|c|c|c|}
\hline \multirow[b]{2}{*}{ Order } & \multirow[b]{2}{*}{ Family } & \multirow[b]{2}{*}{ Scientific name } & \multirow[b]{2}{*}{ Common name } & \multicolumn{4}{|c|}{ Number of individuals by survey type } \\
\hline & & & & VCP & $\begin{array}{l}\text { Line } \\
\text { transect }\end{array}$ & & Incidenta \\
\hline \multirow{30}{*}{ Passeriformes } & Sturnidae & Sturnus vulgaris & European starling & 59 & \multirow{4}{*}{$\begin{array}{l}1 \\
2\end{array}$} & & \multirow[t]{4}{*}{1} \\
\hline & Motacillidae & Anthus rubescens & American pipit & 1 & & & \\
\hline & Ptilogonatidae & Phainopepla nitens & phainopepla & 1 & & & \\
\hline & Parulidae & Vermivora celata & orange-crowned warbler & 1 & & & \\
\hline & & Vermivora ruficapilla & Nashville warbler & 1 & \multirow{13}{*}{26} & & 1 \\
\hline & & Vermivora virginiae & Virginia's warbler & 1 & & & \\
\hline & & Vermivora luciae & Lucy's warbler & 1 & & & \\
\hline & & Dendroica petechia & yellow warbler & 1 & & & \\
\hline & & Dendroica coronata & yellow-rumped warbler & 3 & & & 1 \\
\hline & & Dendroica nigrescens & black-throated gray warbler & & & & 1 \\
\hline & & Oporornis tolmiei & MacGillivray's warbler & 1 & & & \\
\hline & & Wilsonia pusilla & Wilson's warbler & 3 & & & 2 \\
\hline & Thraupidae & Piranga ludoviciana & western tanager & 1 & & & \\
\hline & \multirow[t]{8}{*}{ Emberizidae } & Pipilo chlorurus & green-tailed towhee & 1 & & & 1 \\
\hline & & Spizella passerina & chipping sparrow & 4 & & & \\
\hline & & Spizella breweri & Brewer's sparrow & 130 & & & \\
\hline & & Spizella atrogularis & black-chinned sparrow & & & & 1 \\
\hline & & Pooecetes gramineus & vesper sparrow & 1 & \multirow{5}{*}{46} & & \\
\hline & & Chondestes grammacus & lark sparrow & 2 & & & \\
\hline & & Calamospiza melanocorys & lark bunting & 77 & & & \\
\hline & & Zonotrichia leucophrys & white-crowned sparrow & 3 & & & \\
\hline & \multirow[t]{6}{*}{ Icteridae } & Agelaius phoeniceus & red-winged blackbird & 106 & & & \\
\hline & & Sturnella neglecta & western meadowlark & & \multirow{5}{*}{75} & & 1 \\
\hline & & Quiscalus mexicanus & great-tailed grackle & 111 & & & \\
\hline & & Molothrus aeneus & bronzed cowbird & & & & 1 \\
\hline & & Molothrus ater & brown-headed cowbird & 4 & & & \\
\hline & & Icterus bullockii & Bullock's oriole & 5 & & & 1 \\
\hline & \multirow[t]{2}{*}{ Fringillidae } & Carpodacus mexicanus & house finch & 131 & \multirow[t]{2}{*}{19} & & \multirow[t]{2}{*}{2} \\
\hline & & Carduelis psaltria & lesser goldfinch & 3 & & & \\
\hline & Passeridae & Passer domesticus & house sparrow & 95 & 4 & & 6 \\
\hline Number of spec & & & & 63 & 32 & 4 & 36 \\
\hline
\end{tabular}

a "Wildlife of Special Concern"; Arizona Game and Fish Department (HDMS 2004).

๖ "Species of Concern"; U.S. Fish and Wildlife Service (HDMS 2004).

c "Priority species"; Arizona Partners in Flight (Latta et al. 1999).

d "Sensitive species"; Bureau of Land Management (HDMS 2004).

\begin{tabular}{|c|c|c|c|}
\hline Order & Family & Scientific name & Common name \\
\hline \multirow[t]{4}{*}{ Carnivora } & Mustelidae & Taxidea taxus & American badger \\
\hline & Mephitidae & Mephitis mephitis & striped skunk \\
\hline & Canidae & Canis familiaris & domestic dog \\
\hline & Felidae & Felis catus & domestic cat \\
\hline \multirow[t]{7}{*}{ Rodentia } & Sciuridae & Spermophilus tereticaudus & round-tailed ground squirrel \\
\hline & Heteromyidae & Perognathus amplus taylori & Arizona pocket mouse \\
\hline & & Chaetodipus penicillatus & Sonoran Desert pocket mouse \\
\hline & & Dipodomys merriami & Merriam's kangaroo rat \\
\hline & Muridae & Peromyscus maniculatus & deer mouse \\
\hline & & Onychomys torridus & southern grasshopper mouse \\
\hline & & Neotoma albigula & western white-throated woodrat \\
\hline \multirow[t]{2}{*}{ Lagomorpha } & Leporidae & Lepus californicus & black-tailed jackrabbit \\
\hline & & Sylvilagus audubonii & desert cottontail \\
\hline
\end{tabular}


Appendix E. Amphibian and reptile species not recorded by University of Arizona Inventory personnel but that are likely to occur or have occurred historically at Casa Grande Ruins NM based on collections in the area and expert opinion (P. Rosen in Appendix J). Species in bold-faced type are non-native.

\begin{tabular}{|c|c|c|c|c|c|c|}
\hline \multirow[b]{2}{*}{$\begin{array}{l}\text { Order } \\
\text { Family }\end{array}$} & \multirow[b]{2}{*}{ Scientific name } & \multirow[b]{2}{*}{ Common name } & \multicolumn{2}{|c|}{ Presence } & \multicolumn{2}{|c|}{ Specimen Vouchera } \\
\hline & & & Expected & $\begin{array}{c}\text { Not } \\
\text { expected }^{b}\end{array}$ & Monument ${ }^{c}$ & $\begin{array}{c}\text { Surrounding } \\
\text { lands }^{d}\end{array}$ \\
\hline \multicolumn{7}{|l|}{ Caudata } \\
\hline Ambystomatidae & Ambystoma tigrinum & tiger salamander & \multirow{6}{*}{$X$} & $x$ & & 1 \\
\hline Anura & & & & & & \\
\hline Pelobatidae & Spea multiplicata & Mexican spadefoot & & & & \\
\hline Bufonidae & Bufo woodhousii & Woodhouse's toad & & $X$ & & 10 \\
\hline \multirow[t]{2}{*}{ Ranidae } & Rana yavapaiensis & lowland leopard frog & & $\mathrm{X}$ & & \\
\hline & Rana catesbeiana & American bullfrog & & $\mathrm{X}$ & & 3 \\
\hline \multicolumn{3}{|l|}{ Testudines } & & $x$ & & \\
\hline Kinosternidae & Kinosternon sonoriense & Sonoran mud turtle & & $x$ & & \\
\hline Emydidae & Terrapene ornata & western box turtle & & $\mathrm{X}$ & & \\
\hline Testudinidae & Gopherus agassizii sonoran & desert tortoise & & & & \\
\hline Trionychidae & Trionyx spiniferus & spiny softshell & & $\mathrm{X}$ & & 1 \\
\hline \multicolumn{7}{|l|}{ Squamata } \\
\hline \multirow[t]{2}{*}{ Iguanidae } & Dipsosaurus dorsalis & desert iguana & & & & 40 \\
\hline & Sauromalus obesus & common chuckwalla & & & & 2 \\
\hline \multirow[t]{2}{*}{ Crotaphytidae } & Crotaphytus nebrius & Sonoran collared lizard & & & & 1 \\
\hline & Gambelia wislizenii & long-nosed leopard lizard & & & & 9 \\
\hline \multirow[t]{5}{*}{ Phrynosomatidae } & Callisaurus draconoides & zebra-tailed lizard & & & & 91 \\
\hline & Sceloporus clarkii & Clark's spiny lizard & & & & \\
\hline & Urosaurus ornatus & ornate tree lizard & & & & \\
\hline & Phrynosoma platyrhinos & desert horned lizard & & & & 35 \\
\hline & Phrynosoma solare & regal horned lizard & & & & 5 \\
\hline Helodermatidae & Heloderma suspectum & Gila monster & \multirow{5}{*}{$\begin{array}{l}X \\
X\end{array}$} & & & 23 \\
\hline Leptotyphlopidae & Leptotyphlops humilis & western blind snake & & & 1 & 3 \\
\hline \multirow[t]{11}{*}{ Colubridae } & Phyllorhynchus decurtatus & spotted leaf-nosed snake & & & 1 & 3 \\
\hline & Phyllorhynchus browni & saddled leaf-nosed snake & & & & 2 \\
\hline & Chilomeniscus cinctus & variable sand snake & & & 1 & 3 \\
\hline & Salvadora hexalepis & western patch-nosed snake & & & & 1 \\
\hline & Arizona elegans & glossy snake & \multirow[b]{4}{*}{$X$} & & \multirow{9}{*}{2} & 17 \\
\hline & Thamnophis eques & Mexican garter snake & & $\mathrm{X}$ & & \\
\hline & Thamnophis marcianus & checkered garter snake & & $\mathrm{X}$ & & 5 \\
\hline & Sonora semiannulata & western ground snake & & & & 3 \\
\hline & Chionactis occipitalis & western shovel-nosed snake & $x$ & & & 6 \\
\hline & Tantilla hobartsmithi & $\begin{array}{l}\text { southwestern black-headed } \\
\text { snake }\end{array}$ & & & & 1 \\
\hline & Hypsiglena torquata & night snake & $X$ & & & 4 \\
\hline \multirow[t]{2}{*}{ Viperidae } & Crotalus cerastes & sidewinder & & & & 23 \\
\hline & Crotalus molossus & black-tailed rattlesnake & & & & 1 \\
\hline \multicolumn{7}{|c|}{$\begin{array}{l}\text { Data from Phil Rosen (unpublished data). Due to proprietary information, we cannot report collection information associated with } \\
\text { these specimens except those specimens referenced in Appendix H. } \\
\text { b Riparian-associated species. May have been present historically but not likely present in the monument now (see Appendix J). } \\
\text { c Specimen collected at Casa Grande Ruins NM. Data from Rosen (Appendix J) or Appendix H. } \\
\text { d Museum locality records for the area of Casa Grande National Monument and surrounding Pinal County, taken from an area of largely } \\
\text { homogeneous, lowland desert flats, bounded roughly by the communities of Maricopa, Queen Creek, Florence Junction, Florence, and } \\
\text { Casa Grande. }\end{array}$} \\
\hline
\end{tabular}


Appendix F. Bird species that were not recorded by University of Arizona Inventory personnel but that may occur at Casa Grande Ruins NM. List based on range maps (Sibley 2000), nearby Breeding Bird Survey routes (Sauer et al. 2004) and knowledge of physical conditions at the monument. Species are those most likely to occur and not those considered "accidental" ( $<5$ observations in many areas of southern Arizona).

\begin{tabular}{|c|c|c|c|}
\hline Order & Family & Scientific name & Common name \\
\hline Ciconifformes & Cathartidae & Coragyps atratus a & black vulture \\
\hline \multirow[t]{2}{*}{ Falconiformes } & Accipitridae & Buteo albonotatus & zone-tailed hawk \\
\hline & & Aquila chrysaetos & golden eagle \\
\hline Columbiformes & Columbidae & Columbina passerina ${ }^{b}$ & common ground-dove \\
\hline \multirow[t]{3}{*}{ Strigiformes } & Strigidae & Megascops kennicottii & western screech-owl \\
\hline & & Micrathene whitneyi & elf owl \\
\hline & & Asio otus & long-eared owl \\
\hline \multirow[t]{2}{*}{ Apodiformes } & Apodidae & Aeronautes saxatalis & white-throated swift \\
\hline & Trochilidae & Selasphorus rufus & rufous hummingbird \\
\hline \multirow[t]{2}{*}{ Piciformes } & Picidae & Melanerpes lewis & Lewis's woodpecker \\
\hline & & Sphyrapicus nuchalis & red-naped sapsucker \\
\hline \multirow[t]{51}{*}{ Passeriformes } & Tyrannidae & Contopus cooperia & olive-sided flycatcher \\
\hline & & Empidonax hammondii & Hammond's flycatcher \\
\hline & & Empidonax oberholseri & dusky flycatcher \\
\hline & & Empidonax difficilis & pacific-slope flycatcher \\
\hline & & Empidonax occidentalis & cordilleran flycatcher \\
\hline & & Sayornis nigricans & black phoebe \\
\hline & & Pyrocephalus rubinus & vermilion flycatcher \\
\hline & & Myiarchus tuberculifer & dusky-capped flycatcher \\
\hline & & Myiarchus tyrannulus ${ }^{a}$ & brown-crested flycatcher \\
\hline & & Tyrannus vociferans & Cassin's kingbird \\
\hline & Vireonidae & Vireo bellii & Bell's vireo \\
\hline & & Vireo vicinior & gray vireo \\
\hline & & Vireo plumbeus & plumbeous vireo \\
\hline & & Vireo cassinii & Cassin's vireo \\
\hline & & Vireo huttoni & Hutton's vireo \\
\hline & & Vireo gilvus & warbling vireo \\
\hline & Corvidae & Aphelocoma californica & western scrub-jay \\
\hline & Hirundinidae & Progne subis & purple martin \\
\hline & & Tachycineta bicolor & tree swallow \\
\hline & & Hirundo rustica & barn swallow \\
\hline & Aegithalidae & Psaltriparus minimus & bushtit \\
\hline & Troglodytidae & Catherpes mexicanus & canyon wren \\
\hline & & Thryomanes bewickii & Bewick's wren \\
\hline & & Troglodytes aedon & house wren \\
\hline & Regulidae & Regulus calendula & ruby-crowned kinglet \\
\hline & Turdidae & Sialia mexicana & western bluebird \\
\hline & & Sialia currucoides & mountain bluebird \\
\hline & & Myadestes townsendi & Townsend's solitaire \\
\hline & & Catharus ustulatus & Swainson's thrush \\
\hline & & Catharus guttatus & hermit thrush \\
\hline & Mimidae & Toxostoma bendirei & Bendire's thrasher \\
\hline & & Toxostoma leconteib & Le Conte's thrasher \\
\hline & & Toxostoma crissale & crissal thrasher \\
\hline & Bombycillidae & Bombycilla cedrorum & cedar waxwing \\
\hline & Parulidae & Dendroica townsendi & Townsend's warbler \\
\hline & Emberizidae & Pipilo fuscus & canyon towhee \\
\hline & & Aimophila cassinii & Cassin's sparrow \\
\hline & & Aimophila ruficeps & rufous-crowned sparrow \\
\hline & & Spizella atrogularis & black-chinned sparrow \\
\hline & & Junco hyemalis & dark-eyed junco \\
\hline & Cardinalidae & Cardinalis cardinalis & northern cardinal \\
\hline & & Cardinalis sinuatus & pyrrhuloxia \\
\hline & & Pheucticus melanocephalus & black-headed grosbeak \\
\hline & & Guiraca caerulea & blue grosbeak \\
\hline & & Passerina amoena & lazuli bunting \\
\hline & & Passerina cyanea & indigo bunting \\
\hline & Icteridae & Xanthocephalus xanthocephalus & yellow-headed blackbird \\
\hline & & Euphagus cyanocephalus & Brewer's blackbird \\
\hline & & Icterus cucullatus & hooded oriole \\
\hline & & Icterus parisorum & Scott's oriole \\
\hline & Fringillidae & Coccothraustes vespertinus & evening grosbeak \\
\hline
\end{tabular}

a Observed on "Cactus Forest" Breeding Bird Survey route (Sauer et al. 2004).

b Observed on "Coolidge" Breeding Bird Survey route (Sauer et al. 2004). 
Appendix G. Mammal species not recorded by University of Arizona Inventory personnel but that may be found at Casa Grande Ruins NM based on known habitat associations and range. Burt and Grossenheider (1976) was used only for range maps of bats.

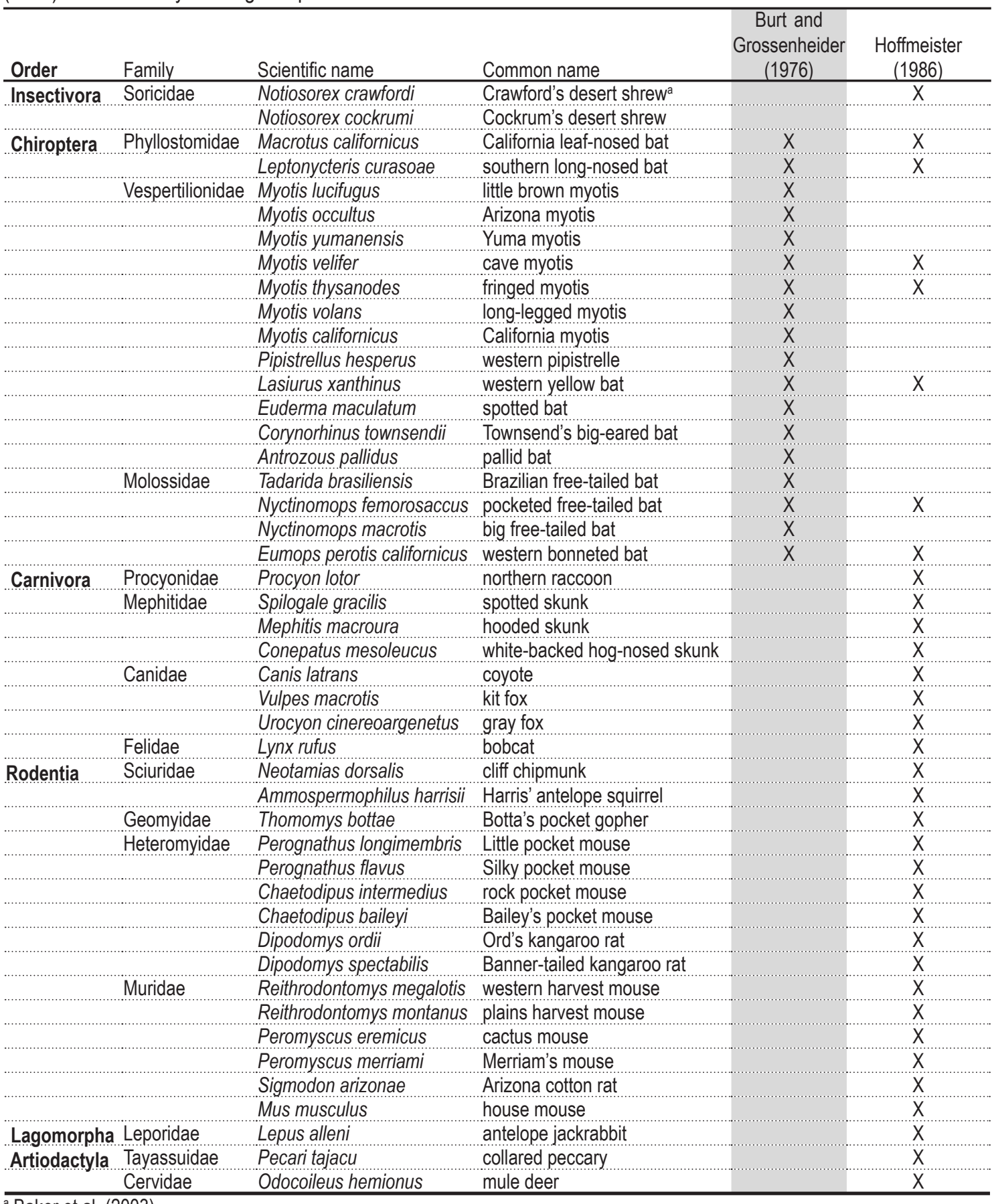

a Baker et al. (2003) 
Appendix H. Vertebrate specimen vouchers from Casa Grande Ruins NM that were not collected by University of Arizona Inventory personnel. See Table 1.1 for list of collections that were queried for specimens with "Casa Grande Ruins" in the location field(s).

\begin{tabular}{|c|c|c|c|c|c|}
\hline $\begin{array}{l}\text { Taxon } \\
\text { group }\end{array}$ & Common name & Scientific name & Collection & $\begin{array}{l}\text { Catalog } \\
\text { number }\end{array}$ & Date collected \\
\hline \multirow[t]{3}{*}{ Reptile } & eastern kingsnake $^{a}$ & Lampropeltis getulus & Chicago Academy of Science & 4701 & August 1, 1938 \\
\hline & coachwhip & Masticophis flagellum & Chicago Academy of Science & 16068 & September 2, 1941 \\
\hline & $\begin{array}{l}\text { spotted leaf-nose } \\
\text { snake }\end{array}$ & Phyllorhynchus decurtatus & Chicago Academy of Science & 7132 & September 1, 1940 \\
\hline \multirow[t]{3}{*}{ Mammal } & western mastiff bat & Eumops perotis & University of Arizona & 238 & March 22, 1944 \\
\hline & western mastif bat & Eumops perotis & University of Arizona & 916 & March 22, 1944 \\
\hline & cottontail & Sylvilagus species & University of California, Berkeley & 123191 & April 20, 1905 \\
\hline
\end{tabular}

a Identification questionable - most likely common kingsnake.

Appendix I. Photograph and specimen vouchers collected at Casa Grande Ruins NM by University of Arizona Inventory personnel, 2001 and 2002. All specimens are located in respective University of Arizona collections.

\begin{tabular}{|c|c|c|c|c|}
\hline Group & Common name & $\begin{array}{l}\text { Number of } \\
\text { photographs }\end{array}$ & Number of specimens & Catalog number(s) \\
\hline Plant & night-blooming cereus & 2 & & \\
\hline \multirow[t]{3}{*}{ Amphibian } & Couch's spadefoot & 1 & 1 & \\
\hline & Sonoran desert toad & 1 & & \\
\hline & Great Plains toad & 1 & & \\
\hline \multirow{11}{*}{ Reptile } & western banded gecko & 1 & & \\
\hline & desert spiny lizard & 2 & & \\
\hline & common side-blotched lizard & 1 & & \\
\hline & long-tailed brush lizard & 2 & & \\
\hline & western (tiger) whiptail & 2 & & \\
\hline & coachwhip & 1 & & \\
\hline & gopher snake & 2 & & \\
\hline & common kingsnake & 2 & & \\
\hline & long-nosed snake & 2 & & \\
\hline & western diamond-backed rattlesnake & 2 & & \\
\hline & Mojave rattlesnake & 3 & & \\
\hline Bird & Harris's hawk & 2 & & \\
\hline \multirow[t]{7}{*}{ Mammal } & American badger & & 1 & 26771 \\
\hline & Arizona pocket mouse & & 2 & 26853,26898 \\
\hline & Sonoran Desert pocket mouse & & 4 & $26917,26892,26920,26918$ \\
\hline & Merriam's kangaroo rat & & 3 & $26886,26928,26890$ \\
\hline & deer mouse & & 1 & 26870 \\
\hline & southern grasshopper mouse & & 1 & 26849 \\
\hline & black-tailed jackrabbit & 1 & & \\
\hline
\end{tabular}




\section{Appendix J. Report by Phil Rosen on the expected and historical occurrence of amphibians and reptiles of Casa Grande National Monument. Report date: 6 August 2004.}

The expected original herpetofauna of Casa Grande Ruins NM is primarily that of the Mohave Desert and Lower Colorado Valley province of the Sonoran Desert - the "true desert" herpetofauna of North America. The monument lies in the relatively less arid, northeastern region of the Mohave-Lower Colorado Valley herpetofaunal region, and is adjoining the Gila River, both factors tending to add elements of less xeric faunas - that of the thornscrub-like Arizona Upland floristic province of the Sonoran Desert, and that of the riparian and aquatic environments of the Gila River and its ancient canal system.

Thus, the expected original herpetofauna, while numerically dominated by true desert species, is increased by characteristic Arizona Upland species like the Sonoran desert toad, Mexican spadefoot, variable sand snake, southwestern black-headed snake, tree lizard, and Clark's spiny lizard, which also may be riparian associated, and regal horned lizard and saddled leaf-nosed snake, which are Arizona Upland but not riparian associated. In addition, certain aquatic- and stream-associated species such as the Woodhouse Toad, lowland leopard frog, checkered garter snake, Mexican garter snake, and Sonoran mud turtle may have, or likely, occurred at the site prior to upstream diversions of the Gila River.

The currently expected herpetofauna would not include any of the aquatic species, except perhaps the Woodhouse toad; would probably not include the riparian-associated species except perhaps the Sonoran desert toad; and, due to the surrounding environmental degradation, probably would not include the non-riparian Arizona Upland species. However, monument expansion or ecological restoration in the area could justifiably target habitat for any of these species as a benchmark or goal.

Associated with the monument's position near the transition from Lower Colorado Valley to Arizona Upland, to unique subspecies that have radically declined due to agriculture and, more recently, urbanization of the eastern Sonoran Desert, would be expected - the Tucson shovelnosed snake (Chionactis occipitalis klauberi) and the Maricopa leaf-nosed snake (Phyllorhynchus browni lucidus).

Appendix E, showing museum records for the regional environs of Casa Grande National Monument, tends to bear out these expectations. Although most of the expected aquatic species were not recorded, this may reflect lack of collecting prior to the habitat degradation: Woodhouse toad and checkered garter snake were recorded, probably because they were originally abundant and can adapt to modern agriculture. Although the Mexican spadefoot was not in the sample for Appendix E, it was collected once just outside the area. Clark's spiny lizard, which was not found, probably is highly sensitive to riparian loss in such an arid region, and would not be expected to have survived nearby, even if it was once present.

Appendices B and E confirm the expectation that the monument's herpetofauna should be dominated by species characteristic of and abundant in the Lower Colorado Valley: lizards - side-blotched lizard, tiger whiptail, zebra-tailed lizard, desert iguana, western banded gecko, desert horned lizard, desert spiny lizard, and long-tailed brush lizard; snakes - sidewinder, gopher snake, glossy snake, and Mohave rattlesnake, as well as the occurrence of both the shovel-nosed and the leaf-nosed snakes. The proximity to Arizona Upland and former riparian conditions may be reflected in the abundance of such species as the longnosed snake and western diamondback, and the presence of the saddled leaf-nosed snake, banded sand snake, southwestern black-headed snake, regal horned lizard, and tree lizard. Overall, the arid characteristic of the regional herpetofauna is well represented in Appendices B and E, and, at a minimum, most or all species abundantly represented in it might well be expected today in habitat like that found at the monument.

Thus, the loss of riparian-associated species 
is fully expected, and the absence of Arizona Upland species is not surprising, the recent lack of records for zebra-tailed lizard, desert iguana, and some other species suggests either more observation is needed, or, more likely, that effects of habitat fragmentation, isolation, and simplification may be fairly profound already at the monument. Other examples of species whose absence would suggest effects of small reserve size or habitat simplification at the monument include the leopard lizard, sidewinder, glossy snake, leaf-nosed snakes, and western shovel-nosed snake. Among these species, two that are difficult to find even if present, and that are represented by subspecies that may be globally threatened, are the saddled leaf-nosed snake (subspecies: Maricopa leaf-nosed snake) and western shovel-nosed snake (subspecies: Tucson shovel-nosed snake). These, along with other species listed in this paragraph, could be appropriate targets for an initial expansion of conservation efforts in the region of Casa Grande National Monument. 
Appendix K. Frequency of detections of birds at each VCP station, Casa Grande Ruins NM, 2001 and 2002. Data are scaled by sample size $(n)$ and are from all observations made during eight-minute counts at stations (including flyovers and birds observed at unlimited distances).

\begin{tabular}{|c|c|c|c|c|c|c|c|c|c|c|c|c|}
\hline \multirow[b]{2}{*}{ Common name } & \multicolumn{12}{|c|}{ Station number } \\
\hline & $\begin{array}{c}1 \\
(n=8)\end{array}$ & $\begin{array}{c}2 \\
(n=8)\end{array}$ & $\begin{array}{c}3 \\
(n=6)\end{array}$ & $\begin{array}{c}4 \\
(n=5)\end{array}$ & $\begin{array}{c}5 \\
(n=6)\end{array}$ & $\begin{array}{c}6 \\
(n=8)\end{array}$ & $\begin{array}{c}7 \\
(n=8)\end{array}$ & $\begin{array}{c}8 \\
(n=8)\end{array}$ & $\begin{array}{c}9 \\
(n=8)\end{array}$ & $\begin{array}{c}10 \\
(n=8)\end{array}$ & $\begin{array}{c}11 \\
(n=8)\end{array}$ & $\begin{array}{c}12 \\
(n=5)\end{array}$ \\
\hline Gambel's quail & 2.1 & 2.0 & 1.8 & 0.8 & & 0.9 & 2.0 & 1.5 & 1.4 & 2.5 & 0.6 & 1.2 \\
\hline Swainson's hawk & & & & & & 0.1 & & & & & & \\
\hline red-tailed hawk & & & & & & & & & & & 0.1 & \\
\hline American kestrel & 0.6 & 0.1 & & & & & 0.1 & & 0.1 & 0.4 & 0.1 & \\
\hline prairie falcon & & & & & & & & & 0.1 & 0.1 & & \\
\hline sandhill crane & & & 2.0 & & & & & & & & & \\
\hline killdeer & & 0.1 & & & & & & & & & & \\
\hline black-necked stilt & 0.3 & & & & & & & & & & & \\
\hline rock pigeon & & 1.0 & 4.3 & 14.4 & 0.5 & & & & & & & 0.4 \\
\hline white-winged dove & & 1.3 & 0.3 & 0.4 & 0.5 & & 0.3 & 0.4 & 0.4 & & 0.1 & 0.4 \\
\hline mourning dove & 4.0 & 7.9 & 6.8 & 8.6 & 6.3 & 6.0 & 5.8 & 4.4 & 5.6 & 3.5 & 5.4 & 8.6 \\
\hline Inca dove & 0.3 & & & & & & & & & & & \\
\hline burrowing owl & & & 0.2 & & 0.3 & & & & 0.8 & & 0.3 & 0.8 \\
\hline lesser nighthawk & & & 0.5 & & & & 0.1 & 0.1 & 0.1 & & 0.1 & \\
\hline black-chinned hummingbird & & 0.4 & 0.3 & 1.8 & & & & & & & & \\
\hline Anna's hummingbird & 0.1 & 0.1 & & 0.6 & & 0.3 & 0.1 & 1.0 & & 0.4 & & \\
\hline Costa's hummingbird & & & & & & 0.1 & & & & 0.1 & & \\
\hline Gila woodpecker & 0.6 & 0.1 & & 0.2 & & 0.1 & 0.6 & 0.6 & 0.5 & 0.1 & & \\
\hline ladder-backed woodpecker & & & & & & & 0.1 & & & & & \\
\hline gilded flicker & 0.5 & 0.1 & 0.2 & & 0.2 & 0.5 & 0.6 & 0.1 & 0.1 & 0.8 & 0.1 & \\
\hline western wood-pewee & & & & & & 0.1 & & 0.1 & & & & \\
\hline Say's phoebe & & & & & & 0.1 & & & & & & \\
\hline ash-throated flycatcher & & & 0.2 & & 0.3 & 0.4 & 0.4 & 0.1 & 0.3 & 0.3 & 0.4 & 0.2 \\
\hline western kingbird & 0.1 & & & & 0.2 & 0.3 & & & 0.1 & & 0.1 & 0.4 \\
\hline loggerhead shrike & & 0.1 & & & & & & 0.1 & 0.3 & & & \\
\hline common raven & & & & & & & 0.1 & & & & 0.3 & 0.4 \\
\hline horned lark & & & & & 0.2 & 0.1 & & 0.5 & 1.5 & & & 0.4 \\
\hline cliff swallow & 9.6 & 0.4 & 0.2 & 1.2 & 0.3 & 0.4 & 4.4 & 6.0 & 11.3 & & 0.1 & \\
\hline verdin & 0.3 & 0.5 & & 0.2 & 0.2 & & 0.3 & & & 0.3 & & 0.6 \\
\hline cactus wren & 0.8 & 0.3 & 0.3 & & & & 0.3 & 0.6 & 0.1 & & & 0.2 \\
\hline northern mockingbird & 0.1 & 0.4 & 0.5 & 0.8 & 0.5 & 0.3 & 0.3 & 0.1 & & 0.1 & 0.1 & 0.6 \\
\hline curve-billed thrasher & & & 0.2 & & & & & & & & & \\
\hline European starling & 3.9 & 0.5 & & & & & 0.4 & 1.5 & & & & 1.4 \\
\hline American pipit & & & & & & & 0.1 & & & & & \\
\hline yellow warbler & & & & 0.2 & & & & & & & & \\
\hline MacGillivray's warbler & & & & & & & & & & 0.1 & & \\
\hline Wilson's warbler & & & & & & & & & & 0.3 & & \\
\hline western tanager & & & & 0.2 & & & & & & & & \\
\hline chipping sparrow & & & & & & 0.3 & & & & & & \\
\hline Brewer's sparrow & & 1.0 & 1.2 & & 0.2 & 3.6 & 1.8 & 1.6 & & 3.1 & 3.8 & \\
\hline vesper sparrow & & & & & & & & & & 0.1 & & \\
\hline lark sparrow & & & 0.3 & & & & & & & & & \\
\hline lark bunting & & & & & & & & 8.1 & 1.5 & & & \\
\hline red-winged blackbird & 3.9 & & 0.5 & 0.4 & 1.0 & 0.6 & 0.1 & 0.4 & 4.6 & 0.5 & 0.9 & 0.2 \\
\hline great-tailed grackle & 1.6 & 2.0 & 2.5 & 5.2 & 0.8 & 0.5 & 0.5 & 1.8 & 0.4 & 0.4 & 0.5 & 0.8 \\
\hline brown-headed cowbird & 0.3 & 0.3 & & & & & & & & & & \\
\hline Bullock's oriole & & & & & & 0.1 & & & & & & \\
\hline house finch & 5.6 & 1.1 & 0.3 & 1.2 & 1.0 & 1.3 & 1.6 & 1.1 & 1.8 & 1.3 & 0.3 & 1.0 \\
\hline lesser goldfinch & & & & 0.4 & & & 0.1 & & & & & \\
\hline house sparrow & 3.1 & 1.1 & 1.8 & 2.0 & 1.5 & 0.8 & 0.8 & 1.1 & 0.1 & & 1.1 & \\
\hline Number of species & 19 & 21 & 20 & 17 & 16 & 21 & 23 & 21 & 20 & 18 & 18 & 16 \\
\hline
\end{tabular}


Appendix L. Sum and mean frequency of detection (FD) of all bird observations from VCP surveys during four, twoweek time periods, Casa Grande Ruins NM, 2001 and 2002. Sample sizes (n) are the number of stations surveyed during that time period.

\begin{tabular}{|c|c|c|c|c|c|c|c|c|}
\hline \multirow[b]{3}{*}{ Common name } & \multicolumn{8}{|c|}{ Time period } \\
\hline & \multicolumn{2}{|c|}{$\begin{array}{c}\text { April 15-31 } \\
(n=44)\end{array}$} & \multicolumn{2}{|c|}{$\begin{array}{l}\text { May } 1-15 \\
(n=12)\end{array}$} & \multicolumn{2}{|c|}{$\begin{array}{c}\text { May 16-31 } \\
(n=20)\end{array}$} & \multicolumn{2}{|c|}{$\begin{array}{c}\text { June 1-15 } \\
(n=10)\end{array}$} \\
\hline & Sum & FD & Sum & FD & Sum & FD & Sum & FD \\
\hline mallard & 4 & 0.09 & & & & & & \\
\hline Gambel's quail & 82 & 1.86 & 22 & 1.83 & 30 & 1.50 & 6 & 0.60 \\
\hline northern harrier & 1 & 0.02 & & & & & & \\
\hline Swainson's hawk & 1 & 0.02 & & & & & & \\
\hline red-tailed hawk & 1 & 0.02 & & & & & & \\
\hline American kestrel & 6 & 0.14 & & & 6 & 0.30 & 3 & 0.30 \\
\hline prairie falcon & 1 & 0.02 & & & 1 & 0.05 & & \\
\hline sandhill crane & 12 & 0.27 & & & & & & \\
\hline killdeer & 1 & 0.02 & & & & & & \\
\hline black-necked stilt & & & 2 & 0.17 & & & & \\
\hline rock pigeon & 70 & 1.59 & 25 & 2.08 & 12 & 0.60 & 6 & 0.60 \\
\hline white-winged dove & 20 & 0.45 & 8 & 0.67 & 3 & 0.15 & 2 & 0.20 \\
\hline mourning dove & 228 & 5.18 & 145 & 12.08 & 103 & 5.15 & 31 & 3.10 \\
\hline Inca dove & 2 & 0.05 & & & & & & \\
\hline greater roadrunner & 1 & 0.02 & & & & & & \\
\hline burrowing owl & 5 & 0.11 & 4 & 0.33 & 4 & 0.20 & 4 & 0.40 \\
\hline lesser nighthawk & 2 & 0.05 & 2 & 0.17 & 4 & 0.20 & 5 & 0.50 \\
\hline black-chinned hummingbird & 6 & 0.14 & 3 & 0.25 & 5 & 0.25 & & \\
\hline Anna's hummingbird & 12 & 0.27 & 2 & 0.17 & 5 & 0.25 & 1 & 0.10 \\
\hline Costa's hummingbird & 2 & 0.05 & & & & & & \\
\hline Gila woodpecker & 15 & 0.34 & 4 & 0.33 & 4 & 0.20 & & \\
\hline ladder-backed woodpecker & & & 1 & 0.08 & & & & \\
\hline gilded flicker & 2 & 0.05 & 11 & 0.92 & 6 & 0.30 & 10 & 1.00 \\
\hline western wood-pewee & & & 2 & 0.17 & 1 & 0.05 & & \\
\hline gray flycatcher & 1 & 0.02 & & & & & & \\
\hline Say's phoebe & 1 & 0.02 & & & & & & \\
\hline ash-throated flycatcher & 9 & 0.20 & 3 & 0.25 & 4 & 0.20 & 3 & 0.30 \\
\hline western kingbird & 6 & 0.14 & 3 & 0.25 & 1 & 0.05 & 1 & 0.10 \\
\hline loggerhead shrike & 1 & 0.02 & & & 2 & 0.10 & 1 & 0.10 \\
\hline common raven & 3 & 0.07 & 3 & 0.25 & & & & \\
\hline horned lark & 7 & 0.16 & 4 & 0.33 & 6 & 0.30 & 7 & 0.70 \\
\hline cliff swallow & 11 & 0.25 & 306 & 25.50 & 17 & 0.85 & 1 & 0.10 \\
\hline verdin & 8 & 0.18 & 3 & 0.25 & 3 & 0.15 & 1 & 0.10 \\
\hline cactus wren & 13 & 0.30 & 2 & 0.17 & 2 & 0.10 & 2 & 0.20 \\
\hline black-tailed gnatcatcher & & & & & 1 & 0.05 & & \\
\hline northern mockingbird & 16 & 0.36 & 4 & 0.33 & 5 & 0.25 & & \\
\hline curve-billed thrasher & 1 & 0.02 & & & & & & \\
\hline European starling & 35 & 0.80 & 13 & 1.08 & 7 & 0.35 & 4 & 0.40 \\
\hline American pipit & & & 1 & 0.08 & & & & \\
\hline phainopepla & & & & & 1 & 0.05 & & \\
\hline orange-crowned warbler & 1 & 0.02 & & & & & & \\
\hline Nashville warbler & 1 & 0.02 & & & & & & \\
\hline Virginia's warbler & 1 & 0.02 & & & & & & \\
\hline Lucy's warbler & 1 & 0.02 & & & & & & \\
\hline yellow warbler & & & 1 & 0.08 & & & & \\
\hline yellow-rumped warbler & 3 & 0.07 & & & & & & \\
\hline MacGillivray's warbler & & & 1 & 0.08 & & & & \\
\hline Wilson's warbler & 2 & 0.05 & 1 & 0.08 & & & & \\
\hline western tanager & & & 1 & 0.08 & & & & \\
\hline green-tailed towhee & 1 & 0.02 & & & & & & \\
\hline chipping sparrow & 4 & 0.09 & & & & & & \\
\hline Brewer's sparrow & 130 & 2.95 & & & & & & \\
\hline vesper sparrow & 1 & 0.02 & & & & & & \\
\hline lark sparrow & 2 & 0.05 & & & & & & \\
\hline
\end{tabular}




\begin{tabular}{|c|c|c|c|c|c|c|c|c|}
\hline \multirow[b]{3}{*}{ Common name } & \multicolumn{8}{|c|}{ Time period } \\
\hline & \multicolumn{2}{|c|}{$\begin{array}{c}\text { April 15-31 } \\
(n=44)\end{array}$} & \multicolumn{2}{|c|}{$\begin{array}{l}\text { May 1-15 } \\
(n=12) \\
\end{array}$} & \multicolumn{2}{|c|}{$\begin{array}{c}\text { May 16-31 } \\
(n=20)\end{array}$} & \multicolumn{2}{|c|}{$\begin{array}{c}\text { June } 1-15 \\
(n=10)\end{array}$} \\
\hline & Sum & FD & Sum & FD & Sum & $\mathrm{FD}$ & Sum & $\mathrm{FD}$ \\
\hline lark bunting & 77 & 1.75 & & & & & & \\
\hline white-crowned sparrow & 3 & 0.07 & & & & & & \\
\hline red-winged blackbird & 61 & 1.39 & 33 & 2.75 & 10 & 0.50 & 2 & 0.20 \\
\hline great-tailed grackle & 45 & 1.02 & 39 & 3.25 & 23 & 1.15 & 4 & 0.40 \\
\hline brown-headed cowbird & 3 & 0.07 & & & 1 & 0.05 & & \\
\hline Bullock's oriole & 4 & 0.09 & 1 & 0.08 & & & & \\
\hline house finch & 44 & 1.00 & 29 & 2.42 & 49 & 2.45 & 9 & 0.90 \\
\hline lesser goldfinch & 1 & 0.02 & 2 & 0.17 & & & & \\
\hline house sparrow & 33 & 0.75 & 31 & 2.58 & 26 & 1.30 & 5 & 0.50 \\
\hline Number of species & \multicolumn{2}{|c|}{54} & \multicolumn{2}{|c|}{33} & \multicolumn{2}{|c|}{29} & \multicolumn{2}{|c|}{21} \\
\hline
\end{tabular}


Appendix M. Summary of vegetation characteristics measured at bird survey stations, Casa Grande Ruins NM, 2002.

\begin{tabular}{|c|c|c|c|c|c|c|c|c|c|}
\hline \multirow[b]{2}{*}{ Station } & \multirow[b]{2}{*}{ Category } & \multirow[b]{2}{*}{ Common name } & \multirow[b]{2}{*}{$\mathrm{N}$} & \multicolumn{2}{|c|}{$\begin{array}{c}\text { Distance from } \\
\text { subpoint }\end{array}$} & \multicolumn{2}{|c|}{ Plant height } & \multicolumn{2}{|c|}{ Canopy diameter } \\
\hline & & & & Mean & SE & Mean & SE & Mean & SE \\
\hline \multirow[t]{8}{*}{1} & Subshrub & creosote bush & 17 & 22 & 4.2 & 0.8 & 0.05 & 0.8 & 0.09 \\
\hline & Shrub & creosote bush & 20 & 10 & 2.6 & 1.8 & 0.09 & 2.2 & 0.15 \\
\hline & Tree & saguaro & 1 & 85 & & 6.0 & & 3.0 & \\
\hline & & creosote bush & 11 & 27 & 4.8 & 2.8 & 0.08 & 3.6 & 0.24 \\
\hline & & velvet mesquite & 8 & 60 & 19.3 & 4.7 & 0.29 & 5.1 & 0.51 \\
\hline & Cavity & saguaro & 3 & 121 & 22.0 & 6.0 & 0.00 & 2.7 & 0.13 \\
\hline & & candy barrel cactus & 2 & 82 & 58.5 & 1.6 & 0.00 & 0.5 & 0.05 \\
\hline & & velvet mesquite & 14 & 60 & 10.0 & 5.9 & 0.63 & 7.4 & 0.62 \\
\hline \multirow[t]{6}{*}{2} & Subshrub & candy barrel cactus & 1 & 14 & & 0.5 & & 0.4 & \\
\hline & & creosote bush & 19 & 14 & 2.8 & 0.7 & 0.06 & 0.6 & 0.06 \\
\hline & Shrub & creosote bush & 20 & 3 & 0.3 & 1.5 & 0.07 & 1.6 & 0.11 \\
\hline & Tree & creosote bush & 14 & 37 & 5.0 & 2.8 & 0.08 & 3.0 & 0.20 \\
\hline & & velvet mesquite & 6 & 45 & 8.8 & 3.8 & 0.31 & 3.5 & 0.57 \\
\hline & Cavity & velvet mesquite & 20 & 32 & 3.2 & 2.9 & 0.17 & 5.0 & 0.44 \\
\hline \multirow[t]{5}{*}{6} & Subshrub & creosote bush & 20 & 6 & 1.2 & 0.8 & 0.04 & 0.8 & 0.06 \\
\hline & Shrub & creosote bush & 20 & 3 & 0.5 & 1.4 & 0.07 & 1.7 & 0.18 \\
\hline & Tree & creosote bush & 12 & 46 & 7.8 & 2.7 & 0.04 & 2.7 & 0.18 \\
\hline & & velvet mesquite & 8 & 77 & 13.8 & 4.4 & 0.18 & 4.8 & 0.28 \\
\hline & Cavity & velvet mesquite & 19 & 29 & 2.8 & 2.4 & 0.19 & 3.7 & 0.39 \\
\hline \multirow[t]{9}{*}{8} & Subshrub & fourwing saltbush & 7 & 10 & 1.4 & 0.7 & 0.08 & 0.9 & 0.22 \\
\hline & & creosote bush & 13 & 24 & 5.1 & 0.8 & 0.04 & 0.6 & 0.10 \\
\hline & Shrub & fourwing saltbush & 1 & 25 & & 1.0 & & 1.4 & \\
\hline & & creosote bush & 19 & 10 & 1.9 & 1.8 & 0.08 & 2.1 & 0.21 \\
\hline & Tree & creosote bush & 17 & 41 & 7.4 & 2.9 & 0.06 & 2.7 & 0.15 \\
\hline & & velvet mesquite & 2 & 8 & 0.5 & 5.4 & 1.40 & 7.5 & 1.50 \\
\hline & & Lycium sp. & 1 & 8 & & 3.1 & & 5.0 & \\
\hline & Cavity & candy barrel cactus & 1 & 25 & & 1.6 & & 0.4 & \\
\hline & & velvet mesquite & 19 & 48 & 7.2 & 3.1 & 0.19 & 4.8 & 0.70 \\
\hline \multirow[t]{5}{*}{11} & Subshrub & creosote bush & 20 & 9 & 0.7 & 0.9 & 0.03 & 0.7 & 0.08 \\
\hline & Shrub & creosote bush & 20 & 4 & 0.4 & 1.6 & 0.08 & 1.8 & 0.12 \\
\hline & Tree & creosote bush & 13 & 52 & 10.4 & 2.6 & 0.02 & 2.1 & 0.05 \\
\hline & & velvet mesquite & 1 & 175 & & 3.1 & & 2.2 & \\
\hline & Cavity & velvet mesquite & 15 & 51 & 13.5 & 2.7 & 0.18 & 2.6 & 0.26 \\
\hline \multirow[t]{5}{*}{12} & Subshrub & creosote bush & 18 & 8 & 1.1 & 0.9 & 0.04 & 0.8 & 0.08 \\
\hline & Shrub & creosote bush & 20 & 3 & 0.4 & 1.7 & 0.09 & 2.0 & 0.12 \\
\hline & Tree & creosote bush & 14 & 25 & 4.8 & 2.7 & 0.03 & 2.4 & 0.15 \\
\hline & & velvet mesquite & 6 & 94 & 16.3 & 4.2 & 0.19 & 4.0 & 0.42 \\
\hline & Cavity & velvet mesquite & 20 & 26 & 3.1 & 2.0 & 0.18 & 3.2 & 0.30 \\
\hline
\end{tabular}

\begin{tabular}{|c|c|c|c|c|c|c|}
\hline \multirow[b]{2}{*}{ Station } & \multicolumn{3}{|c|}{$\begin{array}{l}\text { Mean vegetation } \\
\text { volume }(\%)\end{array}$} & \multicolumn{3}{|c|}{ Coverage (\%) } \\
\hline & $0-0.5 \mathrm{~m}$ & $>0.5-2.0 \mathrm{~m}$ & $>2.0 \mathrm{~m}$ & Litter & Bare ground & Rocks \\
\hline 1 & 7 & 6 & 1 & 9 & 89 & 0 \\
\hline 2 & 11 & 10 & 1 & 11 & 89 & 0 \\
\hline 6 & 13 & 8 & 0 & 10 & 90 & 0 \\
\hline 8 & 7 & 3 & 1 & 16 & 83 & 0 \\
\hline 11 & 14 & 10 & 0 & 10 & 90 & 0 \\
\hline 12 & 16 & 10 & 1 & 15 & 84 & 0 \\
\hline
\end{tabular}


